\title{
EUROPEAN COMMUNITY COMMUNICATIONS LAW: AN INTRODUCTION
}

\author{
Mira Burri-Nenova*
}

\section{INTRODUCTION}

The Treaty establishing the European Economic Community ${ }^{1}$ did not mention telecommunications as such and until the early 1980s telecommunications was not considered a priority sector for the EC. The European Commission had equally no distinct policy approach towards the sector. ${ }^{2}$ Telecommunications were almost identical with the provision of the plain voice telephony service carried out by the national Public Telecommunications Operators (PTOs). ${ }^{3}$ These were exempted from national and European Community competition law and fell under the category of undertakings, which had been granted special or exclusive rights in the general economic interest in the sense of Article 86(1) EC. ${ }^{4}$

\footnotetext{
${ }^{*}$ Mira Burri-Nenova is a senior research fellow at the World Trade Institute at the University of Bern, Switzerland and an alternate leader of the research project "eDiversity: The Legal Protection of Cultural Diversity in a Digital Networked Environment", which is part of the Swiss National Centre of Competence in Research 'Trade Regulation'. Contact at mira.burri@wti.org. The present work is an abridged chapter of the book by Mira Burri-Nenova, EC Electronic Communications and Competition Law, London: Cameron May, 2007.

${ }^{1}$ Treaty establishing the European Economic Community (Rome, 25 March 1957). It is adequate at this early stage of the elaboration on EC law to make a remark as to the terminology that will be used throughout the work. The document most often referred to and the primary source of EC telecommunications law is the Treaty establishing the European Community (consolidated version, OJ C 325/33, 24 December 2002). The abbreviation used for the latter is "EC" or "EC Treaty". "EC" will also be used to signify the "European Community", which is the name given to the "European Economic Community" with the Treaty on European Union (Maastricht Treaty, OJ C 191/1, 29 July 1992). The Maastricht Treaty established the "European Union", which will be shortly referred to as "EU" Following Maastricht and Amsterdam Treaties (OJ C 340/1, 10 November 1997), the EC is one of the three constituent pillars of the EU, the other two being the "Common Foreign and Security Policy" and the "Cooperation in Justice and Home Affairs". The latter two are of inter-governmental nature in contrast to the EC, which is a supra-national entity. The Treaty of Amsterdam changed further, among others, the numbering of the EC Treaty. To avoid confusion, we shall refer to the EC Treaty using the post-Amsterdam numbering system, even in cases of pre-Amsterdam applications. Where appropriate references will be made also to the recently adopted but not yet ratified Treaty establishing a Constitution for Europe (provisional consolidated version, OJ C 310/1, 16 December 2004). The latter document renders obsolete the existing pillar structure of the EU and the term "European Community" as well. It also envisages a new Treaty renumbering.

2 VOLKER SCHNEIDER and RAYMUND WERLE, "Regime oder korporativer Akteur? Die EG in der Telekommunikationspolitik", Max-Planck-Institute Discussion Paper No 88/4, 1988, pp.17-46, as referred to by OLIVER STEHMANN, Network Competition for European Telecommunications, Oxford: Oxford University Press, 1995, at p. 147. The first real measure attempting to give some kind of Community dimension was Recommendation 84/549/EEC of 12 November 1984 concerning the implementation of harmonisation in the field of telecommunications, OJ L 298/49, 16 November 1984.

3 OLIVER STEHMANN, ibid. at p. 147.

${ }^{4}$ On services of general economic interest, see PAUl NiHOUl and PETER RODFORD, EU Electronic Communications Law, Oxford: Oxford University Press, 2004, at paras 5.265 et seq. For account of the forces at play during that period, both at Member State and Community level, see MARK THATCHER, "The Europeanisation of Regulation: The Case of Telecommunications", EUI Working Paper RSC No 1999/22.
} 
The latter exemption was for the first time put to the test in the British Telecommunications case. ${ }^{5}$ Therein, the European Court of Justice (ECJ) confirmed the position of the Commission 6 that EC competition rules did apply to the telecommunications sector and thus established legal limits to the monopoly structure of the sector. The ECJ made it clear that it would favour a narrow interpretation of the scope of derogation under Article 86(2) EC (ex Article 90(2) EEC) from obligations under competition law and that "the application of Art. 90(2) of the Treaty is not left to the discretion of the Member State, which has entrusted an undertaking with the operation of a service of general economic interest. Art. 90(3) assigns to the Commission the task of monitoring such matters". ${ }^{7}$

British Telecommunications is a groundbreaking case for the EC communications sector. ${ }^{8}$ It is of significance at least in three aspects: (i) firstly, for acknowledging the application of Community's competition rules to telecommunications and thus challenging the position of the European PTOs; (ii) secondly, for stressing the role of the Commission as regards services of general economic interest; 9 and (iii) thirdly, as a first sign of the distinct telecommunications policy that the European Community was to adopt and persistently pursue in the years that followed in the direction of liberalising and deregulating the European telecommunications markets. ${ }^{10}$

The EC communications law, as will be discussed in the following Sections, is a product of the latter policy that has accordingly evolved through time. It involved a multiplicity of regulatory models to manage the transition to competition, whereby each regulatory model has been building upon the previously existing ones, preserving certain elements of them, and constantly in evolution. ${ }^{11}$ In that sense, telecommunications law should be viewed as a dynamic rather than a static mixture of pieces of regulation. ${ }^{12}$

\footnotetext{
${ }^{5}$ Commission Decision of 10 December 1982, British Telecom, OJ 1987 L 360/36, [1987] 1 CMLR 457; confirmed in Case 41/83 Italy v. Commission (British Telecommunications) [1985] ECR 873, [1985] 2 CMLR 368.

${ }^{6}$ Ibid. The Commission found that BT, at that time like the other PTOs still a state-owned monopoly, had abused its dominant position in the telecommunications market by taking measures to hinder private forwarding agencies from relaying telex messages between foreign countries over the UK network and offering the service at prices lower than those charged by BT for its international telex service. One of the main issues was how far Article 86(2) EC (ex Article 90(2) EEC) could be applied to exempt BT's abuse of its dominant position. The Court of Justice confirmed the view of the Commission that the retransmission of telex messages was not covered by Article 86(2) exception for public service obligations and that the network operator was not entitled to restrict third parties' use of the network for commercial services in competition with the network operator or with network operators in other Member States.

${ }^{7}$ Case 41/83 Italy v. Commission (British Telecommunications), supra note 5, at para. 30.

8 Although it did not directly lead to opening of the telecommunications markets. See PIERRE LAROUCHE, Competition Law and Regulation in European Telecommunications, Oxford/Portland, Oregon: Hart Publishing, 2000, at p. 3.

${ }_{9}$ See further infra Section 3.1.1.

${ }^{10}$ On deregulation and the concrete liberalisation and harmonisation measures for European telecommunications, see infra Section 3.1.

11 PierRe LAROUCHe, supra note 8 , at p. 1.

${ }^{12}$ See e.g. Commission Guidelines on market analysis and the assessment of significant market power under the Community regulatory framework for electronic communications networks and services, OJ C 165/6, 11 July 2002, at para. 13.
} 
Moreover, besides its dynamism and evolving nature, EC communications law could be characterised by its unique multi-level and "multifarious"13 structure. Indeed, the existing European Community regulatory framework for e-communications does not consist of a single body of law. It represents a fairly complex system, where several bodies of law have to be considered. These are the (i) EC competition rules; (ii) the communications sector specific regulation; and (iii) the obligations of the European Communities as party to the WTO multilateral agreements. ${ }^{14}$ In addition, there is the level of national legislation of the Member States implementing the Community's primary and secondary law ${ }^{15}$ that one has to bear in mind. Since, however, Community rules take precedence over the national ones ${ }^{16}$ and could be directly applied by the national regulatory agencies and the courts, ${ }^{17}$ we shall concentrate our analysis on the European Community's level only. ${ }^{18}$ This exercise in reducing the complexity of the EC communications law will also allow us to discern clearly the model(s) of regulation.

Minding the foregoing, the first step into the mazes of European Community communications law will be to outline the main provisions of EC competition law.

\section{EUROPEAN COMMUNITY COMPETITION LAW}

The EC competition rules are found in Title VI of the Treaty establishing the European Community ${ }^{19}$ along with the provisions relating to tax and approximation of laws. Chapter

${ }^{13}$ An expression used by Ian Walden. See IAN WALDEN, “Telecommunications Law and Regulation: An Introduction" in IAN WALDEN and JoHn ANGeL (eds.), Telecommunications Law and Regulation, $2^{\text {nd }}$ edition, Oxford: Oxford University Press, 2005, pp. 1-22, at p. 13.

${ }^{14}$ Other Treaty Articles having regard to EC telecommunications, apart from the ones on competition, are Article 16 EC on services of general economic interest, Article 154-156 introduced by the Maastricht Treaty (OJ C 191/1, 29 July 1992) on "TransEuropean Networks" and Article 157 introduced by the Treaty of Nice (OJ C 280/1, 10 March 2001) on "Industry".

${ }^{15}$ See e.g. Recital 9 of Council Regulation (EC) 1/2003 of 16 December 2002 on the implementation of the rules on competition laid down in Articles 81 and 82 of the Treaty, OJ L 1/1, 4 January 2003. For an account of the different national competition law legislation, see RICHARD WHISH, Competition Law, $5^{\text {th }}$ edition, London: Butterworths LexisNexis, 2003, at pp. 57 et seq. For an account of the different communications specific legislation, see Colin D. LONG (general ed.), Global Telecommunications Law and Practice, London: Sweet and Maxwell, 2000-2004 and Jos DuMORTIER (ed.), Cyber Law, Vol. 1 and 2 in ROGER BLANPAIN (general ed.), International Encyclopaedia of Laws, The Hague/London/Boston: Kluwer Law International, 2005.

${ }^{16}$ See e.g. Case 6/64 Costa v. ENEL [1964] ECR 585, [1964] CMLR 425; Case 14/68 Walt Wilhelm v. Bundeskartellamt [1969] ECR 1, [1969] CMLR 100; Case C-213/89 R v. Secretary of State for Transport (Factortame II) [1991] 1 AC 603, [1990] 3 CMLR 1; Case C221/89 R v. Secretary of State for Transport (Factortame III) [1991] ECR I-3905, [1991] 3 CMLR 589.

${ }_{17}^{17}$ See e.g. Case 26/62 Van Gend en Loos v. Nederlanse Administratie der Belastingen [1963] ECR 1; Case 43/75 Defrenne v. Sabena (II) [1976] ECR 455; Case 41/74 Van Duyn v. Home Office [1974] ECR 1337. See also Recitals 8 and 9 and Article 3 of the Council Regulation (EC) $1 / 2003$ on the implementation of the rules on competition laid down in Articles 81 and 82 of the Treaty, supra note 15.

${ }^{18}$ On the relationship between EC competition law and national competition laws, see RICHARD WHISH, supra note 15, at pp. 75 et seq. and 283 et seq. Generally, on the relationship between Community and national law, see PAUL CRAIG and GRÁINNE DE BÚRCA, EU Law: Text, Cases and Materials, $2^{\text {nd }}$ edition, Oxford: Oxford University Press, 1998, at pp. 163 et seq. (on direct effect) and pp. 255 et seq. (on supremacy).

${ }^{19}$ See supra note 1. On EC competition law, see JONATHAN FAUll and Ali NIKPAY, The EC Law of Competition, Oxford: Oxford University Press, 1999; VALENTINE KORAH, EC Competition Law and Practice, $7^{\text {th }}$ edition, Oxford/Portland, Oregon: Hart Publishing, 2000; P.M. ROTH (ed.), Bellamy and Child European Community Law of Competition, $5^{\text {th }}$ edition, London: Sweet and Maxwell, 2001; RICHARD WHISH, supra note 15. Within the present Section, case law references and excerpts of the latter two are used. 
One therein is entitled "Rules on Competition" and comprises Articles 81 to $89 .{ }^{20}$ As already established, the two central provisions of European Community competition law are Articles 81 and 82 EC (ex Articles 85 and 86 EEC), which deal respectively with anti-competitive agreements and abuse of dominant position. Article 86 EC (ex Article 90 EEC) on public undertakings and undertakings with special or exclusive rights has come to play a special role in the telecommunications sector, since it was made instrumental by the Commission for the opening of the state-protected telecommunications markets to competition. ${ }^{21}$ EC competition law applies further through the Merger Regulation 22 to "all concentrations with a Community dimension". 23

Since EC competition law in itself is not the core subject of this work, the examination that follows will be selective and put in the context of our overall aim to examine the potency of competition rules in the specific ecosystem of communications and their relationship to sectoral rules. The analysis will concentrate on Article $82 \mathrm{EC}$ as the principal tool for controlling unilateral behaviour of dominant firms. The discussion will be based on the primary and secondary EC law, the jurisprudence of the Community Courts, the practice of the European Commission and guidance provided by it in some soft-law documents. In the framework of Article 82 EC, some major antitrust concepts, such as market definition and market power, will be elaborated upon, which will also be of use for the examination of the current Community's sectoral regime for electronic communications networks and services since the latter is based on antitrust methodology.

\subsection{ARTICLE $82 \mathrm{EC}$}

If we say roughly that competition law is about collusion and dominance, then Article 82 EC is directed at the latter. Article $82 \mathrm{EC}$ is a distinct but not the sole antitrust instrument and is "an important companion to Article 81" ${ }^{24}$ Together, they ensure the protection of competition in the context of Article $3(1)(\mathrm{g})$ of the Treaty. While Article 81 EC is concerned with agreements, decisions and concerned practices, i.e. concurrence of wills, which are harmful to competition, Article $82 \mathrm{EC}$ is targeted at the unilateral conduct of dominant firms, who use their market power in an exploitive or anti-competitive manner. ${ }^{25}$

It should be noted at the very onset of our analysis of competition rules that market power is in itself not necessarily a "bad" thing. It is normally acquired through efficiency of the firms

${ }^{20}$ Section 1 therein is entitled "Rules applying to undertakings" and comprises Articles 81-86; Section 2 comprises Articles 87-89 and regards "Aids granted by States".

${ }^{21}$ See infra Section 3.1.

${ }^{22}$ Council Regulation (EC) 139/2004 of 20 January 2004 on the control of concentrations between undertakings, OJ L 24/1, 29 January 2004. The latter applies as of 1 May 2004 and replaced as part of the modernisation of EC competition law the previous Council Regulation (EEC) 4064/89 of 21 December 1989 on the control of concentrations between undertakings, OJ L 395/1, 30 December 1989.

${ }^{23}$ Ibid. at Article 1.

${ }^{24}$ RICHARD WHISH, supra note 15, at p. 175.

${ }_{25}$ On the respective roles of Article 81 and 82 EC, see Case T-41/96 Bayer v. Commission [2000] ECR II 3383, [2001] 4 CMLR 126, at paras $174-175$ 
and a punishment of such efficiency will in fact contradict the very notion of competition. ${ }^{26}$ Nevertheless, market power presents undertakings with the possibilities of limiting output and raising prices, reducing quality or rate of innovation, which are clearly detrimental to consumer welfare. Article 82 EC must ensure that if undertakings use any of these possibilities, such use, or the attempt thereof, will be "punished" and "corrected".

As a tool of market power control, Article 82 EC is especially important for the telecommunications sector. Indeed, the monopolistic history of the industry, the persisting de facto (if not anymore de jure) dominance of the incumbents and the network externalities intrinsic to communications markets call for its vigilant application.

\subsection{CONSTITUENT Elements OF ARTicle 82 EC}

Upon the textual basis of Article 82 as contained in the EC Treaty, ${ }^{27}$ one can identify the following constituent elements that need to be present in order for an abuse of dominance to be established:

(i) a dominant position held by one or more undertakings in the common market or substantial part thereof;

(ii) an abuse of that dominant position; and

(iii) an actual or potential effect on trade between Member States.

The next paragraphs will concentrate on the concepts of dominance and abuse of dominance in the specific environment of electronic communications. As for the notion of undertaking, ${ }^{28} \mathrm{a}$ telecommunications enterprise, state-owned or otherwise, will with great probability qualify as undertaking insofar as it carries an economic activity..$^{29}$ The fact that an undertaking has a

${ }^{26}$ The Chicago School of economic thought is especially keen on the idea of efficiency. See, among others, ROBERT H. BORK, The Antitrust Paradox: A Policy at War with Itself, New York: The Free Press, 1993 (first published New York: Basic Books, 1978) and Richard POSNER, Antitrust Law, $2^{\text {nd }}$ edition, Chicago/London: University of Chicago Press, 2001.

27 The text of Article $82 \mathrm{EC}$ is as follows:

Any abuse by one or more undertakings of a dominant position within the common market or in a substantial part of it shall be prohibited as incompatible with the common market in so far as it may affect trade between Member States. Such abuse may, in particular, consist in:

(a) directly or indirectly imposing unfair purchase or selling prices or other unfair trading conditions;

(b) limiting production, markets or technical development to the prejudice of consumers;

(c) applying dissimilar conditions to equivalent transactions with other trading parties, thereby placing them at a competitive disadvantage;

(d) making the conclusion of contracts subject to acceptance by the other parties of supplementary obligations which, by their nature or according to commercial usage, have no connection with the subject of such contracts.

${ }^{28}$ The EC Treaty provides no explicit definition of what constitutes an "undertaking". The term has been interpreted broadly by the Court of Justice and the Court of First Instance to mean any natural or legal person that carries on (or has the ability to carry on) an economic activity, regardless of its legal status or the way in which it is financed (see e.g. Case C-41/90 Höfner $\mathcal{E}$ Elser v. Macrotron [1991] ECR I-1979, [1993] 4 CMLR 306 and Case 170/83 Hydrotherm v. Compact [1984] ECR 2999, [1985] 3 CMLR 224. It is irrelevant whether the undertaking has in fact a profit motive (see e.g. Case C-55/96 Job Centre (No 2) [1997] ECR I-7119, [1998] 4 CMLR 708 and Case C-41/90 Höfner \& Elser v. Macrotron, ibid.). See Commission Notice on the concept of undertakings concerned, OJ C 66/14, 2 March 1998. See also RICHARD WHISH, supra note 15, at pp. 80-90 and 177 and JONATHAN FAULL and ALI NiKPAY, supra note 19 , at paras 2.21 et seq.

${ }^{29}$ See e.g. Case 41/83 Italy v. Commission (British Telecommunications), supra note 5. The 1991 Guidelines on the application of EEC competition state that, "TOs [telecommunications organisations] are undertakings within the meaning of Articles 85 and 86 
monopoly conferred upon it by statute will not exclude it from the scope of application of Article 82 EC. ${ }^{30}$ The third criterion of an effect on intra-Community trade, which is in essence a jurisdictional standard defining the scope of application of Community competition law, ${ }^{31}$ will normally be fulfilled in electronic communications cases, since the abusive practices of communications firms ${ }^{32}$ will easily meet the appreciability test of having an actual, potential, direct or indirect influence on the pattern of trade between Member States. ${ }^{33}$ The relevant geographic market is not a defining factor in this context and trade between Member States may be equally affected in cases where the relevant market is national or sub-national. ${ }^{34}$

\subsubsection{DOMINANCE}

The first element of the legal test of Article $82 \mathrm{EC}$ and a key concept of antitrust is the finding of dominance. The European Court of Justice has defined dominance for the purposes of Article 82 EC as:

“...a position of economic strength enjoyed by an undertaking which enables it to hinder the maintenance of effective competition on the relevant market by allowing it to behave to an appreciable extent independently of its competitors and customers and ultimately of consumers" ${ }^{35}$

Pursuant to this definition, determining whether a firm holds a dominant position involves essentially three inter-related analytical stages:

[now 81 and $82 \mathrm{EC}$ ] to the extent that they exert an economic activity, for the manufacturing and/or sale of telecommunications equipment and/or for the provision of telecommunications services, regardless of other facts such as, for example, whether their nature is economic or not and whether they are legally distinct entities or form part of the State organization". See Guidelines on the application of EEC competition rules in the telecommunications sector, OJ C 233/2, 6 September 1991, at para. 20 (footnote omitted).

${ }^{30}$ See e.g. Case 311/84 Centre Belge d'Etudes de Marché Télémarketing v. CLT [1985] ECR 3261, [1986] 2 CMLR 558, at para. 16 and Case C-18/93 Corsica Ferries [1994] ECR I-1783, at para. 43.

${ }^{31}$ See e.g. Joined Cases 56/64 and 58/64 Consten and Grundig [1966] ECR 429, [1966] CMLR 418 and Joined Cases 6 and 7/73 Istituto Chemioterapico Italiano SpA and Commercial Solvents Corp v. Commission [1974] ECR 223, [1974] I CMLR 309. Effect on trade is also the criterion that determines the scope of application of Article 3 of Regulation 1/2003 on the implementation of the rules on competition laid down in Articles 81 and 82 EC (supra note 15).

${ }^{32}$ The effect on trade test is common for both Articles 81 and $82 \mathrm{EC}$. In the case of Article $82 \mathrm{EC}$, it is the abuse that must affect trade between Member States. This does not imply, however, that each element of the behaviour must be assessed in isolation. Conduct that forms part of an overall strategy pursued by the dominant undertaking must be assessed in terms of its overall impact. Where a dominant undertaking adopts various practices in pursuit of the same aim, for instance, practices that aim at eliminating or foreclosing competitors, in order for Article $82 \mathrm{EC}$ to be applicable to all the practices forming part of this overall strategy, it is sufficient that at least one of these practices is capable of affecting trade between Member States. See in this respect Case 85/76 Hoffmann-La Roche v. Commission [1979] ECR 461, [1979] 3 CMLR 211, at para. 126.

${ }^{33}$ The test was first defined in Case 56/65 Société Technique Minière v. Maschinenbau Ulm [1966] ECR 235, [1966] CMLR 357. See also Case 172/80 Züchner v. Bayerische Vereinsbank AG [1981] ECR 2021, [1982] 1 CMLR 313, at para. 18; Case 319/82 Kerpen and Kerpen [1983] ECR 4173; Joined Cases 240/82 etc. Stichting Sigarettenindustrie [1985] ECR 3831, at para. 48; Joined Cases T-25/95 etc. Cimenteries CBR [2000] ECR II-491, at para. 3930.

${ }^{34}$ The Commission Guidelines on the effect on trade provide a thorough examination of the case law in this respect. See Guidelines on the effect on trade concept contained in Articles 81 and 82 of the Treaty, OJ C 101/81, 27 April 2004, at paras 77 et seq.

${ }^{35}$ Case 27/76 United Brands v. Commission [1978] ECR 207, [1978] 1 CMLR 429, at para. 65; Case 85/76 Hoffmann-La Roche v. Commission [1979] ECR 461, [1979] 3 CMLR 211, at para. 38. 
(i) market definition, i.e. defining the relevant product and geographic market in which the market power of the allegedly dominant undertaking is to be assessed;

(ii) market share analysis, i.e. establishing the market share of the undertaking in question on the so defined relevant market; and closely related;

(iii) an analysis of competitive constraints, i.e. assessing the significance attributable to the market share of the undertaking and in particular, whether it is likely to be eroded by actual or potential competitors within a certain time frame and analysis of other factors allowing the undertaking to behave "independently of its competitors and customers and ultimately of consumers". ${ }^{36}$

\subsubsection{MARKET DEFINITION}

It is important to always bear in mind that the concept of dominance is not an abstract one. An undertaking can only have dominance upon a certain market for the supply of particular goods or services. ${ }^{37}$ Thus, "[t]he definition of the relevant market is of essential significance" for the finding of dominance. ${ }^{38}$ Other things being equal, the narrower the product or service market, the easier it is to conclude that an undertaking has the requisite dominance for the purposes of Article 82 EC. ${ }^{39}$

The Commission's Notice on the definition of the relevant market for the purposes of Community competition law (hereinafter the Relevant Market Notice ${ }^{40}$ ) clarifies the role and process of market definition. Paragraph 2 of the Notice states: "Market definition is a tool to identify and define the boundaries of competition between firms. It serves to establish the framework within which competition policy is applied by the Commission. The main purpose of market definition is to identify in a systematic way the competitive constraints that the undertakings involved face. The objective of defining a market in both its product and geographic dimension is to identify those actual competitors of the undertakings involved that are capable of constraining those undertakings' behaviour and of preventing them from behaving independently of effective competitive pressure". ${ }^{41}$

As we shall see below in the course of the present Chapter, market definition is by no means an automatic exercise, especially in the communications sector, where technology evolves and changes at a substantial pace and new markets constantly emerge. It may require the use of

\footnotetext{
${ }^{36}$ Ibid.

${ }^{37}$ See e.g. Case C-209/98 Enteprenørforeningens Affalds/Miljøsektion (FFAD) v. Københavns Kommune [2000] ECR I-3743, at para. 57 and Case C-242/95 GT-Link [1997] ECR I-4449, at para. 36.

38 Joined Cases T-125/97 and T-127/97 The Coca-Cola Company and Others v. Commission [2000] ECR II-1733, [2000] 5 CMLR 467, at paras 81-83. Market definition is needed not only for the purposes of applying Article $82 \mathrm{EC}$. For all circumstances in which a definition of the relevant market is necessary, see RICHARD WHISH, supra note 15, at pp. 26-27.

${ }^{39} \mathrm{~A}$ textbook example in that regard is the United Brands case (supra note 35) where the applicant argued that bananas were in the same market as other fruit. The ECJ pointed out that this issue depended on whether the banana could be "singled out by such special features distinguishing it from other fruits that it is only to a limited extent interchangeable with them and is only exposed to their competition in a way hardly perceptible" (see para. 22 of the judgment). For a case, where extremely narrow market definition was applied, see e.g. Football World Cup 1998, OJ [2000] L 5/55, [2000] 4 CMLR 963.

${ }^{40}$ OJ C 372/5, 9 December 1997.

${ }^{41}$ Emphasis added.
} 
sophisticated econometrics methods, as well as a thorough understanding of the functioning and specificities of the particular market under scrutiny.

The standard approach of the European Commission and the Community Courts to the definition of the relevant market has been to focus on "three main sources of competitive constraints: demand substitutability, supply substitutability and potential competition"42 that firms are subject to. The following Sections will take a closer look at these, trying to pinpoint some of the inherent communications specificities in that context.

\section{A. DEMAND SUBSTITUTABILITY}

The Commission has pointed out that, "[f]rom an economic point of view, for the definition of the relevant market, demand substitution constitutes the most immediate and effective disciplinary force on the suppliers of a given product, in particular to their pricing decisions". ${ }^{43}$ The analysis of demand substitutability is hence an indispensable and defining element of the process of market definition. Its test is meant to determine which products or services are sufficiently similar in function, price and attributes, so as to be regarded by users as reasonable substitutes for each other.

According to the settled case law, the relevant product/service market comprises all those products or services that are sufficiently interchangeable or substitutable to the consumer, not only in terms of their objective characteristics, by virtue of which they are particularly suitable for satisfying the constant needs of consumers, their prices or their intended use, but also in terms of the conditions of competition and/or the structure of supply and demand on the market in question. ${ }^{44}$ Products or services, which are only to a small or relative degree interchangeable with each other do not form part of the same market. ${ }^{45}$

In practice, the way to apply the above fairly abstract definition is the following: After an initial determination of a group of products or services that are used by consumers for the same purpose (end use), the Relevant Market Notice proposes a test, "a speculative experiment", ${ }^{46}$ whereby it becomes possible to determine whether particular products or services are indeed within the same market. The latter test is known as the "SSNIP" test, i.e.

\footnotetext{
42 Relevant Market Notice, at para. 13 (emphasis added). The same rule is reiterated in the Commission Guidelines on market analysis and the assessment of significant market power under the Community regulatory framework for electronic communications networks and services, supra note 12, at para. 38 .

${ }^{43}$ Relevant Market Notice, at para. 13 (emphasis added).

${ }^{44}$ The test of sufficient substitutability or interchangeability was first laid down by the Court of Justice in Case 6/72 Europemballage and Continental Can v. Commission [1973] ECR 215, [1973] CMLR 1999, at para. 32. See also Case 85/76 Hoffmann LaRoche v. Commission supra note 35, at para. 23; Case C-333/94 P Tetra Pak v. Commission [1996] ECR I-5951, [1997] 4 CMLR 662, at para. 13; Case 31/80 L'Oréal [1980] ECR 3775, [1981] 2 CMLR 235, at para. 25; Case 322/81 Michelin v. Commission [1983] ECR 3461, [1985] 1 CMLR 282, at para. 37; Case C-62/86 Akzo Chemie v. Commission [1991] ECR I-3359, [1993] 5 CMLR 215; Case T-504/93 Tiercé Ladbroke v. Commission [1997] ECR II-923, [1997] 5 CMLR 309, at para. 81; T-65/96 Kish Glass v. Commission [2000] ECR II1885, [2000] 5 CMLR 229, at para. 62; Case C-475/99 Ambulanz Glöckner v. Landkreis Südwestpfalz [2001] ECR I-8089, [2002] 4 CMLR 726 , at para. 33 .

${ }_{45}$ Case C-333/94 P Tetra Pak v. Commission, ibid. at para. 13; Case 66/86 Ahmed Saeed Flugreisen v. Zentrale zur Bekampfung Unlauteren Wettbewerbs [1989] ECR 803, [1990] 4 CMLR 102, at paras 39 and 40; Case 27/76 United Brands v. Commission, supra note 35, at paras 22 and 29 and 12; Case T-229/94 Deutsche Bahn v. Commission [1997] ECR II-1689, [1998] 4 CMLR 220, at para. 54.

${ }^{46}$ Relevant Market Notice, at para. 15.
} 
Small but Significant Non-Transitory Increase in Price (also referred to as the "hypothetical monopolist" test) and was first deployed by the US Department of Justice. ${ }^{47}$ Its algorithm is as follows: Starting with the products immediately in issue, additional products are included in or excluded from the market definition depending on the extent to which competition from such products is capable of influencing the pricing of the products under scrutiny. If a hypothetical small (in the range of 5-10 per cent) permanent increase in the price of product $A$ (e.g. Swisscom pre-paid mobile package) would result in customers switching to product B (e.g. Orange pre-paid mobile package) as a readily available alternative ${ }^{48}$ and doing so to an extent sufficient to make the price increase unprofitable, then product $B$ is included with product $\mathrm{A}$ within the relevant market. ${ }^{49}$ The same test is then applied to products $\mathrm{A}$ and $\mathrm{B}$ within this expanded market and products C, D, etc. until the set of products included is such that the hypothetical price increase for the included products would be profitable because no sufficient alternatives remain to which customers could switch. ${ }^{50}$

With regard to the application of the SSNIP test to communications markets, a few specificities should be accounted for. In principle, the hypothetical monopolist test is relevant only with regard to products or services, the price of which is freely determined and not subject to regulation. The working assumption is that current prevailing prices are indeed set at competitive levels. If, however, in a sector like communications, where some type of price regulation exists, a service or product may be offered at a regulated, cost-based price. In the absence of indications to the contrary, it is then presumed that such a price is set at what would otherwise be a competitive level and should therefore be taken as the starting point for applying the SSNIP test. Prices resulting from price regulation however, which does not aim at ensuring that prices are cost-based, but rather at ensuring an affordable offer within the context of universal service, should not be presumed to be set at a competitive level, nor could they serve as a starting point for applying the SSNIP test. ${ }^{51}$

47 The SSNIP test was introduced by the US Department of Justice with the 1982 Merger Guidelines. The latter have been amended by the 1984 Guidelines and superseded in their entirety (except for Section 4) by the present Horizontal Merger Guidelines issued by the US Department of Justice and the Federal Trade Commission in 1992 and revised in April, 1997, see $<$ http://www.usdoj.gov/atr/public/guidelines/horiz_book/hmgl.html>. For an overview on the development of the SSNIP test, see Gregory J. Werden, "The 1982 Merger Guidelines and the Ascent of the Hypothetical Monopolist Paradigm", Antitrust Division Papers, June 2002, available at <http://www.usdoj.gov/atr/hmerger.htm>. On the SSNIP test in EC law, see DORIS HILDEBRAND, "The European School of EC Competition Law" (2002) World Competition, Vol. 25, No 1, pp. 3-23, at pp. 11 et seq.

${ }^{48}$ It is not necessary that all consumers switch to the competing product; it suffices that enough or sufficient switching takes place so that a relative price increase is not profitable. This requirement corresponds to the principle of "sufficient interchangeability" laid down in the case law of the Court of Justice.

${ }^{49}$ Relevant Market Notice, at paras 15-18 and 56-58.

${ }^{50}$ Another factor that must be taken into consideration when applying the SSNIP test are the existing switching costs which may hinder the substitution of products. In a situation where end users face significant switching costs in order to substitute product A for product B, these two products should not be included in the same relevant market. See Guidelines on market analysis and the assessment of significant market power under the Community regulatory framework for electronic communications networks and services, supra note 12, at para. 50 .

${ }^{51}$ Guidelines on market analysis and the assessment of significant market power under the Community regulatory framework for electronic communications networks and services, supra note 12, at para. 42. 
Under normal circumstances, if the demand elasticity ${ }^{52}$ of a given product or service is significant (even at relative competitive prices), the firm in question lacks market power. If, however, elasticity is high even at current prices, that may mean only that the firm in question has already exercised market power to the point that further price increases will not increase its profits. In this case, the prevailing price does not correspond to a competitive price and the application of the hypothetical monopoly test may lead to a different market definition from the one, which would be produced if the prices were set at a competitive level. The Commission Guidelines on market definition and assessment of significant market power in electronic communications point explicitly to this drawback of the SSNIP test - a situation known in antitrust practice as the "cellophane fallacy". ${ }^{53}$

Faced with such a situation, the Commission recommends relying on other criteria for assessing demand and/or supply-side substitution such as functionality of services and technical characteristics. Evidence of past anti-competitive behaviour or dominance may also serve as an indication that the current prices are not under competitive constraint and possibly set above the competitive level..$^{54}$

The use of the SSNIP test could be particularly difficult in electronic communications and other high-technology industries. Such industries are dynamic by their nature, while the SSNIP test draws its conclusions on the basis of a static picture of the market. The difficulties stemming from this discrepancy relate above all to the proper identification of the level of prices to be taken as a benchmark. As Jorge Padilla points out, "[h]igh-tech products are highly differentiated, exhibiting substantial price and performance variations. For example, firms offer various versions of the same underlying product, each of which is tailored to a specific group of users. Different versions have different prices and also different functionalities. This heterogeneity makes it very hard, if not practically impossible, to define an appropriate benchmark". ${ }^{55}$ We shall elaborate upon some other distinct difficulties in the course of the present Chapter.

\section{B. SUPPLY SUBSTITUTABILITY}

While demand substitutability focuses on the interchangeable character of products and services from the buyer's (consumer's) point of view, proper delineation of the relevant market may require further consideration of potential substitutability from the supply side, i.e. from other producers. Supply substitutability is however not always an essential element of

\footnotetext{
52 Demand elasticity or price elasticity of demand is an elasticity that measures the responsiveness of the quantity demanded of a good to its price. See e.g. N. GREGORY MANKIW, Principles of Economics, Mason, Ohio: South-Western, 2004 , at Chapter 5.

53 The name "cellophane fallacy" stems from a US case, United States v. El du Ponte de Nemours and Co, 351 US 377 (1956), which concerned packaging materials, including cellophane. On the cellophane fallacy, see ibid. at para. 42 and footnote 31 . See also RICHARD WHISH, supra note 15 , at pp. 30 et seq.

54 Ibid.

55 Atilano Jorge Padilla, The Role of Supply-Side Substitution in the Definition of the Relevant Market in Merger Control, A Report for DG Enterprise A/4, Madrid, June 2001, at p. 68, referring also to CHRISTOPHER PLEATSIKAS and DAVID TEECE, “The Analysis of Market Definition and Market Power in the Context of Rapid Innovation" (2001) International Journal of Industrial Organization, Vol. 19, Issue 5, pp. 665-693.
} 
the market definition process and is more often taken into account at the level of market analysis, once the relevant market has already been identified. In the Relevant Market Notice, the Commission provides guidance as to the circumstances under which it considers that supply-side substitutability can become part of the market definition. ${ }^{56}$

At paragraph 20 therein, the Commission states that where suppliers are able to switch production to the relevant products and market them "in the short term ${ }^{\prime \prime 7}$ without incurring significant additional costs or risks in response to small and permanent changes in relative prices, then the market may be broadened to include the products that those suppliers are already producing. ${ }^{58}$ Account should also be taken of any existing legal, statutory or other regulatory requirements, which could deter a time-efficient entry into the relevant market and as a result discourage supply-side substitution..$^{59}$

The fact that a rival firm possesses some of the assets required to provide a given service is immaterial if significant additional investment is needed to market and offer profitably the products or services in question. ${ }^{60}$ Furthermore, it should be positively established that a given supplier would actually use or switch its productive assets to produce the relevant product or offer the relevant service. Mere hypothetical supply-side substitution is not sufficient for the purposes of market definition. Where supply substitution is complex and difficult to ascertain, it should be regarded as a matter of determining dominance rather than establishing the market. ${ }^{61}$

\section{POTENTIAL COMPETITION}

The market power of an undertaking can be also constrained by the existence of potential competitors. ${ }^{62}$ This competitive constraint relates to the likelihood that undertakings not currently active on the relevant market may in the medium term decide to enter it following a small but significant non-transitory price increase. Although one could note certain similarities between potential competition and supply-side substitution, as described above, they are indeed distinct categories. What delineates them is above all the length of time from the price increase to the commencement of supply and hence entry into the particular market, as well as the costs related to that entry. With regard to the length of time, supply-side

\footnotetext{
${ }^{56}$ Relevant Market Notice, at paras 20-23.

57 "Short term" is according to the Relevant Market Notice such a term that does not entail a significant adjustment of existing tangible and intangible assets. Ibid. at footnote 4 .

58 The example given by the Commission is the production of paper, whereby suppliers can change relatively swiftly between producing one particular type of paper to producing another. See Relevant Market Notice, at para. 21.

${ }^{59}$ In the electronic communications sector such barriers could be delays and obstacles in concluding interconnection or colocation agreements, negotiating any other form of network access, or obtaining rights of ways for network expansion. See Guidelines on market analysis and the assessment of significant market power under the Community regulatory framework for electronic communications networks and services, supra note 12, at paras 52-54.

${ }^{60}$ See e.g. Case C-333/94 P Tetra Pak v. Commission, supra note 44, at para. 19.

${ }^{61}$ Relevant Market Notice, at paras 14 and 23. See also Commission Notice on the application of the competition rules to access agreements in the telecommunications sector, OJ C 265/3, 22 August 1998 (hereinafter the Access Notice), at para. 41.

${ }^{62}$ See e.g. Decca Navigator System, OJ [1987] L 43/27 and Magill TV Guide/ITP, BBC, RTE [1989] OJ L 78/43. See also Case 22/78 Hugin Kassaregister AB v. Commission [1979] ECR 1869, [1979] 3 CMLR 345; Case 226/84 British Leyland v. Commission [1986] ECR 3263, [1987] 1 CMLR 184.
} 
substitution responds swifter to price increases, while potential entrants may take longer than a year or so to commence supplying the market with their products and/or services. With regard to the entry costs, supply-side substitution means entry without substantial and irreversible investment, while potential entry refers to entry at a substantial sunk cost. ${ }^{63}$

The Commission has pointed out with reference to communications markets that, "[d]istinguishing between supply-side substitution and potential competition [...] may be more complicated than in other markets given the dynamic character of the former. What matters however is that potential entry from other suppliers is taken into consideration at some stage of the relevant market analysis, that is, either at the initial market definition stage or at the subsequent stage of the assessment of market power (SMP)“ ${ }^{64}$

Indeed, in the industries of the new economy, the consideration of supply-side developments may be crucial. ${ }^{65}$ Such industries function differently and it is frequently the case that the main competitive constraint comes not from available demand substitutes but "originates from new, superior products, whose time of introduction is most often uncertain". ${ }^{66}$ Although in practice supply-side substitution and potential competition are attributed a secondary role for the definition of market in comparison to demand substitutability, ${ }^{67}$ this hierarchy may be questionable in electronic communications or other industries driven by technological innovation. ${ }^{68}$ Indeed, in network industries driven by innovation, where the competition is for the market rather than in it, an account of competitors pending to enter could be crucial for the proper definition of the market (and later for the proper finding of market power). An analysis based on a mere snapshot of the current market situation without capturing its development over time may have chilling effects on improving efficiency and innovation.

\footnotetext{
${ }^{63}$ For an excellent analysis of the differences between potential competition and supply-side substitution, see ATILANO JORGE PADILLA, supra note 55, at pp. 19 et seq.

${ }^{64}$ Guidelines on market analysis and the assessment of significant market power under the Community regulatory framework for electronic communications networks and services, supra note 12, at footnote 24 . This is in fact a novel acknowledgement by the Commission that potential competition can also be taken into account at the level of defining the market. The statement is slightly at odds with the Relevant Market Notice, where, at para. 24, the Commission explained that, "[t]he third source of competitive constraint, potential competition, is not taken into account when defining markets, since the conditions under which potential competition will actually represent an effective competitive constraint depend on the analysis of specific factors and circumstances related to the conditions of entry. If required, this analysis is only carried out at a subsequent stage, in general once the position of the companies involved in the relevant market has already been ascertained, and when such position gives rise to concerns from competition point of view".

${ }^{65}$ An example in point is the invention of platforms, such as Skype, offering free software for voice connections over the internet, thus putting in danger conventional fixed-line telephony. See The Economist, "The Meaning of Free Speech", 15 September 2005.

${ }^{66}$ ATILANO JORGE PADILLA, supra note 55, at p. 66. For an extensive discussion of market definition, supply-side substitution and the new economy, see ibid. at pp. 65-79.

${ }^{67}$ See e.g. Relevant Market Notice, at para. 14.

${ }^{68}$ Atilano Jorge Padilla, supra note 55, at p. 9, referring to IRA Horowitz, "Market Definition, Market Power, and Potential Competition" (1992) Quarterly Review of Economics and Business, Vol. 22; ANDREW C. HRUSKA, "A Broad Market Approach to Antitrust Product Market Definition in Innovative Industries" (1992) Yale Law Journal, Vol. 102; HERBERT HovenKAmP, Federal Antitrust Policy, 2nd edition, St. Paul, Minn: West Group, 1999. See also Jordi GuAL, "Market Definition in the Telecommunications Markets Industry" in PIERRE A. BUIGUES and PATRICK REY (eds.), The Economics of Antitrust and Regulation in Telecommunications, Cheltenham, UK: Edward Elgar Publishing, 2004, pp. 45-70.
} 


\section{THE GEOGRAPHICAL MARKET}

The relevant market has not only product/service dimension but also a geographical one. In deciding whether a firm has market power for the purpose of Article $82 \mathrm{EC}$, it is necessary to consider the geographical scope of the market on which it operates in order to determine from which other undertakings it faces competition. According to well-established case law, the relevant geographic market comprises "an area in which the undertakings concerned are involved in the supply and demand of the relevant products or services, in which area the conditions of competition are similar or sufficiently homogeneous and which can be distinguished from neighbouring areas in which the prevailing conditions of competition are appreciably different. ${ }^{69}$

Some products and services can be supplied without difficulty from State to State, throughout the Community or the world (such as typically communications services), while others are of such nature that due to technical or practical reasons can only be distributed to a narrower area. Transport costs are a factor of obvious importance in this regard.

In some instances, the scope of the geographical market will be relatively straightforward. Such was the case in British Telecommunications, ${ }^{70}$ where, as discussed, the issue was whether BT had abused its dominant position with regard to message-forwarding agencies in the United Kingdom. The geographical market was then determined to be the United Kingdom, since at the time, BT had a monopoly over it for the provision of telecommunications services. ${ }^{71}$

In the absence of particular factors, such as special or exclusive rights granted for a certain territory or transport costs, ${ }^{72}$ the relevant geographic market could be held to be the entire European Union..$^{73}$ In the recent Microsoft decision, ${ }^{74}$ the Commission defined the geographic markets for PC operating systems, ${ }^{75}$ work group server operating systems ${ }^{76}$ and media

\footnotetext{
${ }^{69}$ Guidelines on market analysis and the assessment of significant market power under the Community regulatory framework for electronic communications networks and services, supra note 12, at para. 56. See also United Brands, supra note 35, at para. 44; Case 322/81 Michelin v. Commission, supra note 44, at para. 26; Case 247/86 Alsatel v. Novasam [1988] ECR 5987, [1990] 4 CMLR 434, at para. 15; Tiercé Ladbroke v. Commission, supra note 44, at para. 102 and the Relevant Market Notice, at para. 8.

${ }^{70}$ Commission Decision of 10 December 1982, British Telecom, supra note 5; confirmed in Case 41/83 Italy v. Commission (British Telecommunications), ibid. as discussed in Section 1.

${ }^{71} \mathrm{Ibid}$. at para. 2.

72 See e.g. Napier Brown-British Sugar (Commission Decision 88/518, OJ [1988] L 284/41, [1990] 4 CMLR 196.

${ }^{73}$ See e.g. Case C-53/92 P Hilti AG v. Commission [1994] ECR I-667, [1994] 4 CMLR 614.

${ }^{74}$ Commission Decision of 24 March 2004 relating to a proceeding under Article 82 of the EC Treaty, Case COMP/C-3/37.792 Microsoft, C(2004) 900 final. In that decision, the Commission identified three distinct product markets and found that Microsoft had a dominant position on two of them (client PC operating system market and work group server operating system market). The Commission then identified two types of abusive conduct by Microsoft on those markets, namely refusal to supply "interoperability information" (paras 546-791 of the decision) and tying (paras 792-989 of the decision). Consequently, the Commission imposed a fine of $€ 497196304$ and a number of remedies on Microsoft, among others, notably, to provide its competitors with interoperability information and to unbundle Windows Media Player from Windows operating system. After a dismissal of the application for interim measures (see Order of the President of the Court of First Instance of 22 December 2004 in Case T-201/04 R Microsoft Corporation v. Commission of the European Communities, OJ L 69/16, 19 March 2005), the case is currently before the Court of First Instance after Microsoft challenged the Commission's decision in all essential points (see Action brought on 7 June 2004 by Microsoft Corporation against the Commission of the European Communities, Case T-201/04, OJ L C 179/18, 10 July 2004). On the Microsoft case in terms of abuse of dominance, see infra Section 2.3.

${ }^{75} \mathrm{Ibid}$. in particular paras 324-342.
} 
players ${ }^{77}$ to be world-wide. It stated therein that, "[n]either import restrictions, transport costs or technical requirements constitute significant limitations. Language-specific demand characteristics regarding the relevant software exist but, in so far as the supply-side is concerned, do not constitute an obstacle for swift supply on a global basis in accordance with language-related preferences. The entire world can therefore be regarded as the relevant geographic market".$^{78}$

The Relevant Market Notice describes the actual mechanism for determining the geographical scope of the market. At paragraph 28, it states that the Commission "will take a preliminary view [...] on the basis of broad indications as to distribution of market shares between the parties and their competitors, as well as a preliminary analysis of pricing and price differences at national and Community or EEA [European Economic Area] level“. This initial view will be used as a working hypothesis that will be enriched with further analysis of national or local preferences, current patterns of customers' purchases and product differentiation. This survey is to be conducted along the lines of the SSNIP test (as sketched in the framework of product/service market definition), the difference being that, in the case of geographic market definition the question asked is whether, faced with an increase in price, consumers located in a particular area would switch their purchases to suppliers farther away. As far as supply-side substitution is concerned, where it can be established that producers, who are not currently present on the relevant market, will decide to enter it in the short term in the event of a relative price increase, then the market definition should be expanded to incorporate those producers as well.

In the electronic communications sector, the geographical scope of the relevant market has traditionally been determined according to two main criteria, ${ }^{79}$ namely: (i) the area covered by a network ${ }^{80}$ and (ii) the existence of legal or other regulatory instruments. ${ }^{81}$ With the advanced process of digitisation and global interconnectedness, the geographical dimension naturally expands. Linguistic differences remain however relevant. ${ }^{82}$

${ }^{76} \mathrm{Ibid}$. in particular paras 343-401.

$77 \mathrm{Ibid}$. in particular paras 402-425.

$78 \mathrm{Ibid}$. at para. 427.

${ }^{79}$ See, for instance, Case No IV/M.1025 - Mannesmann/Olivetti/Infostrada, [1998] 4 CMLR 407, at para. 17 and Case No COMP/JV.23 - Telefónica Portugal Telecom/Médi Telecom. For a more detailed analysis of geographical aspect of communications markets, see PIERRE LAROUCHE, "Relevant Market Definition in Network Industries: Air Transport and Telecommunications" (2000) Journal of Network Industries, Vol. 1, pp. 407-445, at pp. 417 et seq.

${ }^{80}$ In practice, this area will correspond to the limits of the area in which an operator is authorised to operate. In Case No COMP/M.1650 - ACEA/Telefónica, at para. 16, the Commission pointed out that since the notified joint venture would have a licence limited to the area of Rome, the geographical market could be defined as local.

${ }^{81}$ For instance, the fact that mobile operators can provide services only in the areas where they have been authorised to and that a network architecture reflects the geographical dimension of the mobile licenses explains why mobile markets are considered national in scope. The extra connection and communications costs that consumers face when roaming abroad, coupled with the loss of certain additional service functionalities (such as lack of voice mail) further support this definition. See Case No IV/M.1439 - Telia/Telenor, at para. 124; Case No IV/M.1430 - Vodafone/Airtouch, at paras 13-17; Case No COMP/JV.17 Mannesmann/Bell Atlantic/Omnitel, at para. 15.

82 Guidelines on market analysis and the assessment of significant market power under the Community regulatory framework for electronic communications networks and services, supra note 12, at para. 58. The linguistic factor is especially powerful in the broadcasting markets. See E. JANE CARTER, "Market Definition in the Broadcasting Sector" (2001) World Competition, Vol. 24, No 1, pp. 93-124, at pp. 121 et seq. 
On the basis of these criteria, geographic markets, including such in electronic communications, can be considered to be local, regional, national, covering territories of the two or more countries or, as in the case of Microsoft, global.

\subsubsection{RELEVANT COMMUNICATIONS MARKETS}

The specificities of the electronic communications sector are naturally mirrored in specificities of defining the relevant markets within it. As repeatedly stressed, the communications industry is an innovation-based and highly dynamic one. The development of the markets is driven however as much by technological advances as by the expectations of the consumers, which adds a certain degree of unpredictability intrinsic to the evolution. Furthermore, the communications sector is a converging one. In response to the process of convergence, leading to the deterioration of boundaries between media, information technology and telecommunications industries, new business models are constantly emerging and the existing value chains are being transformed.$^{83}$ The obvious complexity of defining relevant markets in such environment is enhanced by the fact that while the new offerings and services packages "may be distinct from a technological point of view, that is not conclusive for the purposes of defining the relevant market, since the main criterion is sustainability in the eyes of the customer". 84

The case law of the Court of Justice and the Court of First Instance dealing with communications specific situations, especially with abuse of dominance under Article $82 \mathrm{EC}$ is limited. ${ }^{85}$ The European Commission has however adopted a number of decisions under Regulation $17^{86}$ and the Merger Control Regulation, ${ }^{87}$ some of which are of particular relevance to the methodology of market definition in electronic communications. ${ }^{88}$ The

\footnotetext{
${ }^{83}$ An example in point is the acquisition of Skype - a company distributing software enabling people to make free phone calls over the Internet, by eBay - the world largest online marketplace.

${ }^{84}$ PIERRE LAROUCHE, supra note 79, at p. 415 (emphasis added). Pierre Larouche states further that, "[g]iven the wide range of offerings and the ease with which they may be broken down or combined into new packages, the demand-side picture can vary widely from one customer to the other, depending on its needs".

85 PAUl NiHOUl and PETER RODFORD, supra note 4, at paras 4.11-4.12.

${ }^{86}$ Council Regulation (EC) 1/2003 of 16 December 2002 on the implementation of the rules on competition laid down in Articles 81 and 82 of the Treaty, supra note 15.

${ }^{87}$ Council Regulation (EC) 139/2004 on the control of concentrations between undertakings, supra note 22.

88 The Commission has, inter alia, made references in its decisions to the existence of the following markets: international voice-telephony services (Case No IV/M.856 - British Telecommunications/MCI (II), OJ L 336, 8 December 1997); advanced telecommunications services to corporate users (Case No IV/35.337 - Atlas, OJ L 239, 19 September 1996, at paras 5-7; Case No IV/35617 - Phoenix/Global/One, OJ L 239, 19 September 1996, at para. 6; Case IV/34.857 - British Telecommunications/MCI (I), OJ L 223, 27 August 1994); standardised low-level packet-switched data-communications services, resale of international transmission capacity (Case NoIV/M.975 - Albacom/BT/ENI, at para. 24); audio-conferencing (Albacom/BT/ENI, at para. 17); satellite services (Case IV/350518 - Iridium, OJ L 16, 18 January 1997); (enhanced) global telecommunications services (Case No IV/JV.15 - BT/ATET; Case No COMP/M.1741 - MCI WorldCom/Sprint, at para. 84; Case No COMP/M.2257 - France Telecom/Equant, at para. 18); directory-assistance services (Case No IV/M.2468 - SEAT Pagine Gialle/ENIRO, at para. 19; Case No COMP/M.1957 - VIAG Interkom/Telenor Media, at para. 8); Internet-access services to end users (Case No IV/M.1439 Telia/Telenor; Case No COMP/JV.46 - Blackstone/CDPQ/Kabel Nordrhein/Westfalen, at para. 26; Case No COMP/M.1838 - BT/Esat, at para. 7); top-level or universal Internet connectivity (Case No COMP/M.1741 - MCI WorldCom/Sprint, at para. 52); seamless panEuropean mobile telecommunications services to internationally mobile customers (Case No COMP/M.1975 - Vodafone Airtouch/Mannesmann; Case No COMP/M.2016 - France Telecom/Orange, at para. 15); wholesale roaming services (Case COMP/M.1863 - Vodafone/Airtel, at para.17) and market for connectivity to the international signalling network (Case
} 
Commission Guidelines on market analysis and the assessment of significant market power in e-communications (hereinafter the SMP Guidelines), ${ }^{89}$ the current Recommendation on relevant product and service markets within the electronic communications sector susceptible to ex ante regulation (hereinafter the Relevant Market Recommendation) ${ }^{90}$ and the attached Explanatory Memorandum ${ }^{91}$ provide further valuable guidance with regard to the methodology of the Commission and summarise its practice hitherto. These documents are however to be used with caution, firstly, since they are soft-law instruments ${ }^{92}$ and secondly, since they are primarily directed at the National Regulatory Agencies, which conduct ex ante analysis for the purposes of the communications specific regulation. ${ }^{93}$

An important caveat that has to be made with regard to market definition in the electronic communications sector is that the relevant markets are per definition bound to change. As the Commission itself submitted, "[g]iven the pace of technological change in this sector, any attempt to define particular product markets [...] would run the risk of rapidly becoming inaccurate or irrelevant ${ }^{\prime \prime}{ }^{94}$ Consequently, our approach will not be to engage in a concrete analysis of the case law ${ }^{95}$ but rather to point at some specificities of market definition methodology for e-communications. Indeed, in the process of defining communications markets, while applying the standard model of demand, supply substitutability and potential competition, there are a few communications specific issues that have the potential of altering standard rationales and need to be accounted for. ${ }^{96}$

Firstly, although conventionally the end use of a product or service is closely related to its physical characteristics, in communications, different kind of products or services may be used for the same end. For instance, consumers may use dissimilar services, such as cable and

No COMP/2598 - TDC/CMG/Migway JV, at paras 17-18). These cases are referred to by the Commission in its Guidelines on market analysis and the assessment of significant market power under the Community regulatory framework for electronic communications networks and services, supra note 12, at footnote 51 .

${ }^{89} \mathrm{Ibid}$.

${ }^{90}$ Recommendation on relevant product and service markets within the electronic communications sector susceptible to $e x$ ante regulation in accordance with Directive 2002/21/EC, OJ L 114/45, 8 May 2003.

${ }_{91}$ Explanatory Memorandum of the Recommendation on relevant product and service markets within the electronic communications sector susceptible to ex ante regulation in accordance with Directive 2002/21/EC, OJ L 114/45, 8 May 2003.

92 See infra Section 3.2.1.2.

${ }^{93}$ For an analysis of the communications framework, the market definition procedure and its relation to generic competition law, see infra 1.3.2.4.

${ }_{94}$ Access Notice, at para. 47. Reiterated in the SMP Guidelines, at para. 63.

${ }^{95}$ In the communications sector there are at least two types of relevant markets to consider - that of a service to be provided to end users - the services market, and that of access to the facilities necessary to provide that service to end users (information, physical network, etc.) - the so-called access market. In the context of any particular case, within these two broad market definitions further market distinctions may be made depending on the demand and supply patterns. Helpful rule-of-thumb for the analysis could be the division between services provided at fixed locations and those provided to non-fixed locations, as well as the division between voice services and non-voice (data) services, although these distinctions do not imply an advance judgement that these services constitute in fact separate markets. For further guidance, see the Access Notice, at paras 39 et seq.; the SMP Guidelines, in particular at paras 63 et seq. and Explanatory Memorandum of the Recommendation on relevant product and service markets within the electronic communications sector, supra note 91, in particular Section 4. See also PIERRE LAROUCHE, supra note 79, at pp. 425 et seq. and DAVID GILLIES and ROGER MARSHALL, Telecommunications Law, Vol. 1, 2nd edition, London: Butterworths LexisNexis, 2003, at pp. 48 et seq., 84 et seq., 91 et seq.

${ }_{96}$ The following paragraphs are based on the SMP Guidelines, at paras $45 \mathrm{et} \mathrm{seq.} \mathrm{For} \mathrm{an} \mathrm{economic} \mathrm{analysis} \mathrm{of} \mathrm{the} \mathrm{problems}$ related to market definition in communications, see JORDI GUAL, supra note 68, at pp. 53 et seq. 
satellite connections for identical purposes, namely to access the Internet. In such a case, both services may be included in the same product market, although they are technologically distinct. Conversely, paging services and mobile telephony services, which may both appear to be capable of offering the same service, i.e. sending two-way short messages, may be found to belong to different product markets in view of the different perceptions by consumers as regards their functionality and end use. Similarly, although mobile telephony and fixed telephony services appear almost identical as to their end use, they have been (at least until now) considered as distinct markets. ${ }^{97}$

Secondly, differences in pricing models and offerings for a given product or service may also imply different groups of consumers. Thus, based on prices, separate markets for business and residential customers may be defined - notably, for the provision of essentially the same service. Business users may be possibly broken down further into a market for professional, small and medium sized business customers and another for large businesses..$^{98}$

The price of the communications products under scrutiny may not always be an indication of their demand substitutability. This means essentially that in order for products to be viewed as substitutes, it is not necessary that they are offered at the same price. A low quality product or service sold at a low price could well be an effective substitute to a higher quality product sold at corresponding higher prices. What matters in this case, is the likely responses of consumers following a relative price increase. For instance, in case of a relative price increase, consumers of a lower quality/price service may switch to a higher quality/price service if the cost of doing so (the premium paid) is offset by the price increase. Conversely, consumers of a higher quality product may no longer accept a higher premium and switch to a lower quality service. ${ }^{99}$

Furthermore in the context of pricing, since electronic communications are often characterised by high sunk costs and continuous innovation, the benchmark price based on the marginal cost and a small mark-up (5 to 10 per cent), as practised with the SSNIP test, may be insufficient to recoup these fixed costs and therefore would lead to a too narrow market definition. ${ }^{100}$ In the context of the SSNIP, one can note an additional, rather practical, difficulty

${ }_{97}$ Case No COMP/M.2574 - Pirelli/Edizione/Olivetti/Telecom Italia, at para. 33. With regard to fixed telephony and Internet telephony, see EuROPEAN COMMISsion, "Voice over Broadband in France: No Regulation on Internet Telephony Required", IP/05/1146, Brussels, 15 September 2005.

98 The Commission has identified separate markets for services offered to large multinational corporations given the significant differences in the demand (and supply) of services to this group of customers compared to other retail (business) customers. See Case No IV/JV.15 - BT/ATET; Case No COMP/M.1741 - MCI WorldCom/Sprint; Case No COMP/M.2257 - France Télécom/Equant. The current Relevant Market Recommendation distinguishes also between the retail services provided to residential and non-residential customers (respectively, markets 1, 3, 4 and markets 2, 5, 6).

${ }^{99}$ SMP Guidelines, at footnote 34 .

${ }^{100}$ See JORDI GUAL, supra note 68 , at p. 52. The possibility for too narrow market definitions can be easily exemplified by the mobile voice call termination market. In mobile markets the prevalent tariff principle is that the calling-party-pays, i.e. the party who calls (who usually cannot choose the network whom she/he calls) has to pay for the call. There is thus a dichotomy between the person who pays and the one who chooses, or in other words, the called party imposes a negative externality on the calling party. In this sense, it is plausible that the called network may increase profitably its termination charges from 5 to 10 per cent (i.e. the wholesale charges that the calling network pays to the called network to terminate a call) because, on the one hand, the calling network (and ultimately the calling customer) has no choice but to use the called network, and on the other hand, the called customer will not switch to another network as she/he does not pay the termination charge. Each network may thus be defined as 
of applying the test in communications. This difficulty stems (again) from the specificities of the e-communications environment and the inherent possibilities of new markets' emergence and the related lack of evidence to substantiate the test. In many situations, such evidence may be completely missing, where certain communications products and services are really novel (or not yet launched) and markets not yet fully developed. ${ }^{101}$ Indeed, there can be particular situations, where the SSNIP test is not applicable at all, since the availability of free products makes the hypothetical monopolist test impotent. ${ }^{102}$

Thirdly, it is important that one acknowledges the costs of switching between available substitutes. It may often be the case that the possibility for consumers to substitute a product or a service for another due to the small, but significant lasting price increase is hindered by the considerable switching costs involved. Consumers who have invested in technology or made any other necessary investments in order to receive a service or use a product may be unwilling to incur any additional costs involved in switching to an otherwise substitutable service or product. Network effects may additionally contribute to "locking-in" both end users and operators. In such situations, where consumers face significant switching costs in order to substitute product A for product B, these two products should not be included in the same relevant market. ${ }^{103}$ On the other hand, where a market is still growing, total switching costs for already "captured" consumers may not be significant and will normally not deter demand or supply-side substitution. ${ }^{104}$

Another factor that is of significance and may call for wider market definitions (both on the basis of demand and supply-side analysis) is the already elaborated upon process of convergence. The latter "facilitates entry of new products into the relevant market and, in particular, it increases the number of potential points of entry into the market in response to a price increase $"{ }^{105}$ Due to the digitisation and the process of convergence there is in fact an increasing similarity in the performance and characteristics of network services using distinct technologies ${ }^{106}$ and an increased level of product substitutability. The positioning of the

a separate market with regard to wholesale termination. ${ }^{100}$ See the Relevant Market Recommendation (market 16) and Commission Decision of 10 July 2002, Telia/Sonera, Case No COMP/M. 2803, at para. 31.

101 Such was the case in British Interactive Broadcasting, OJ [1999] L 312/1 [2000] 4 CMLR 901), where the Commission stated that it could not delineate the markets for interactive broadcasting services by application of the SSNIP test, since the product had not been launched yet.

102 The Commission has been confronted with such cases in broadcasting, where due to the availability of free-to-air public broadcasting, the SSNIP could not be applied (see e.g. Case No IV/M.553 RTL/Veronica/Endemol OJ [1996] L 134/32). One could imagine that cases could emerge in electronic communications as well, where there is a new tendency of offering free products and services.

103 The Commission has stressed that such switching costs are non-strategic. Switching costs stemming from strategic choices by undertakings rather than from exogenous factors should be considered, together with other form of entry barriers, at the stage of analysis of dominance. See the SMP Guidelines, at para. 50.

104 Ibid.

105 ATILANO JORGE PADILLA, supra note 55, at p. 77.

106 A classical example is the similarity between fixed telephony and VoIP (voice over internet protocol). See e.g. Communication from the Commission - Status of voice on the Internet under Community law, and in particular, under Directive 90/388/EEC - Supplement to the Communication by the Commission to the European Parliament and the Council on the status and implementation of Directive 90/388/EEC on competition in the markets for telecommunications services, OJ C 369/3, 22 December 2000. 
enterprises along the entire value chain and across sectors equally intensifies the supplysubstitutability. This essentially alters the ecosystem of electronic communications.

To conclude radically, in the words of Jorge Padilla, "[m]ost indicia typically used by competition authorities, and in particular the European Commission, to define relevant markets have limited value in high-technology industries. These include the so-called 'SSNIP test', the physical characteristics of product and intended use, the product prices, and consumer preferences or cross-elasticity of demand" ${ }^{107}$ To conclude less radically, one can submit that the specificities of the communications industry have serious ramifications for the process of defining relevant markets within it. Minding this and the extraordinary dynamism of the sector, markets will have to be cautiously delineated on a case-by-case basis taking into account the particular circumstances of the case.

\subsubsection{MARKET ANALYSIS}

Once the product and geographical dimensions of the relevant market have been defined, it then has to be decided whether the undertaking under scrutiny is dominant in that sphere. This involves, as mentioned above, an examination of the competitive constraints that the firm faces in the relevant market with the purpose of establishing whether it could indeed "behave to an appreciable extent independently of its competitors and customers and ultimately of consumers". ${ }^{108}$

\section{A. MARKET SHARES}

The European Court of Justice and the Court of First Instance have regarded market shares as an important indicator of market power. Although market shares are not conclusive and other factors indicating dominance must also be taken into account, they are definitely a good basis to start with the analysis of dominance. ${ }^{109}$ The ECJ considers that high market shares may in fact be evidence of dominance in their own right. In Hoffmann-La Roche, the Court stated in that sense that, "...although the importance of the market shares may vary from one market to another the view may legitimately be taken that very large shares are in themselves, and save in exceptional circumstances, evidence of the existence of a dominant position. An undertaking which has a very large market share and holds it for some time [...] is by virtue of that share in a position of strength...".110 The Court held eventually in the particular case of Hoffmann-La Roche that the market shares ranging between 75 and 87 per cent were "so large that they are in themselves evidence of a dominant position". ${ }^{111}$

${ }^{107}$ Atilano Jorge PADilla, supra note 55, at p. 68. Jorge Padilla goes on to suggest a new approach for identifying markets in the industries of the new economy (see ibid. at pp. 70 et seq.). For a new approach toward market definition in network industries, see PIERRE LAROUCHE, supra note 79, at pp. 421 et seq.

${ }^{108}$ Case 27/76 United Brands v. Commission, at para. 65; Case 85/76 Hoffmann-La Roche v. Commission, at para. 38, both supra note 35 .

109 See Relevant Market Notice, at paras 53-55, where the Commission explains the methods of calculating market shares.

${ }^{110}$ Hoffmann-La Roche $v$. Commission, supra note 35, at paras 40-41 (emphasis added).

$111 \mathrm{Ibid}$. at para. 56. 
The question of what constitutes a "very large market share" was further addressed in AKZO. There the Court referred to the above quoted passage of Hoffmann-La Roche and found that a market share of 50 per cent held over at least three years could also be taken as very large so that, in the absence of exceptional circumstances, the undertaking with such a share will be considered dominant. ${ }^{112}$ The undertaking under scrutiny will have the burden of establishing the opposite. ${ }^{113}$

Following the above line of reasoning, a logical question then is at what point a firm's share is so small that it could not be considered dominant. ${ }^{114}$ Both the ECJ and the Commission held in United Brands ${ }^{115}$ that an undertaking with a market share in the range of 40-45 per cent could still be dominant. In that case, other factors were however considered significant and the market share alone might not have been sufficient to sustain a finding of dominance. The Commission has further pointed out that there may be cases where, depending on the concrete circumstances, a dominant position can be found to exist at levels of 35-40 per cent market share and even below these. ${ }^{116} \mathrm{~A}$ proof that this is indeed possible was the Commission's decision in Virgin/British Airways, ${ }^{117}$ where British Airways was found dominant in the UK's air travel agency services market with a share of 39.7 per cent. In such situations, what can be of particular relevance are the structure of the market and the market shares of the competitors, ${ }^{118}$ as well as the length of the time period over which the large market shares are maintained. ${ }^{119}$

Market shares are, however, not the sole criterion in determining whether a firm has market power. ${ }^{120}$ Market share figures do not show relative efficiencies and do not necessarily mean that similar market shares can be sustained in the future. They represent only a snapshot of the current market situation without capturing their development over time. In communications and other emerging or fast-growing markets, high market shares are less

112 C-62/86 Akzo Chemie BV v. Commission, supra note 44, at para. 60 .

113 The CFI applied this test in Hilti AG v. Commission (Case T-30/89 [1991] ECR II-1439, [1992] 4 CMLR 16).

114 For an excellent overview of market share thresholds, see RICHARD WHISH, supra note 15, at pp. 46-48.

115 See supra note 35.

116 EUROPEAN COMMISSION, X Report on Competition Policy, 1980, at para.50. See also EUROPEAN COMMISSION, DG Competition Discussion Paper on the Application of Article 82 of the Treaty to Exclusionary Abuses, Brussels, December 2005, at para. 31.

117 Virgin/British Airways, OJ [2000] L 30/1, [2000] 4 CMLR 999, on appeal Case T-219/99 British Airways plc v. Commission [2004] 4 CMLR 19. See Sven B. VÖLCKER, “Developments in EC Competition Law in 2003: An Overview" (2004) Common Market Law Review, Vol. 41, pp. 1027-1072, at pp. 1051 et seq.

118 In Case No COMP/M.1741 MCI WorldCom/Sprint, it was for instance found that the merged entity would have in the market for the provision of top-level internet connectivity an absolute combined market share of more than 35-45 per cent, several times larger than its closest competitor, enabling it to behave independently of its competitors and customers (see in particular paras 114, 123, 126, 146, 155 and 196 of the case).

${ }^{119}$ In Hoffmann-La Roche (supra note 35), the firm's share of the vitamin B3 market had been fluctuating over a three-year period between 29 and 51 per cent were not considered a sufficient evidence of dominance.

120 The Commission has pointed out, albeit in the context of ex ante analysis, "[a]s far as the SMP assessment is concerned, it is fair to say that the market shares identified by NRAs remain an important indicator for the finding or non-finding of SMP. However, the Commission would like to stress again that the existence of a dominant position cannot be established on the sole basis of large market shares". See EUROPEAN COMMISSION, European electronic communications regulation and markets 2004, COM(2004) 759 final, 2 December 2004, Vol. I, Annex I “Article 7 Framework Directive Proceedings”, at p. 74. 
indicative of dominance than in mature or slow-growing markets. ${ }^{121} \mathrm{In}$ fact, the incumbent will typically have a large market share, as competition in communications industries often exhibits so-called "winner-takes-all" features. These large market shares are, however, under the permanent pressure of innovating firms not yet operating on the market but with the capacity to enter. ${ }^{122}$

\section{B. BARRIERS TO ENTRY}

Barriers to entry are of primary significance when it comes to factors indicating dominance other than market shares. In fact, barriers to entry should not be just come as a second thought after the obligatory market shares analysis but are to be acknowledged as a pivotal issue in the determination of market power. ${ }^{123}$ From an economic point of view, if there are no barriers to entry to the market in question, the dominance, if one exists, is not likely to persist $\mathrm{t}^{124}$ and should not consequently be punished.

The view of the European Court of Justice, however, does not necessarily correspond to the economic concept of entry barriers. ${ }^{125}$ Pursuant to the Court's practice, the concept of barriers to entry has been construed fairly widely and without any precise economic underpinnings. According to the case law, the following factors have been deemed indicative of dominance as presenting barriers to the entry of competitors in a particular market:

(i) Certain legal provisions of the Member States have been considered as amounting to an entry barrier. For instance, in Hugin Kassaregister, ${ }^{126}$ the ECJ found dominance in the market of spare parts for cash registers being influenced by the fact that other firms could not produce such spare parts for fear of breaching the, then valid, UK Design Copyright Act 1968. In the same way, the ownership of patents, trademarks and other intellectual property may constitute barriers to entry. ${ }^{127}$

\footnotetext{
${ }^{121}$ European Regulators Group for electronic communications networks and services (ERG), Working Paper on the SMP Concept for the New Regulatory Framework, ERG(03) 09rev2, May 2003, at p. 3. See also ATILANO JorGE PADILLA, supra note 55, at pp. 65 et seq.

122 Atilano Jorge Padilla, supra note 55, at p. 67.

${ }^{123}$ ROBERT H. BORK, supra note 26, at pp. 310-311.

124 The importance of barriers to entry for competition from an economic perspective was first stressed by Joe S. Bain (JOE S. BAIN, Barriers to New Competition, Cambridge, MA: Harvard University Press, 1956). Bain outlined four specific entry barriers: scale economy, product differentiation, absolute cost and capital requirement. The later theory of contestable markets (see the seminal work of William J. BAUMOL, JOHN C. PANZAR and ROBERT D. Willig, Contestable Markets and the Theory of Industry Structure, New York: Harcourt Brace Jovanovich, 1982) pointed further the significance of sunk costs as barriers to entry. For a concise introduction to the economic theories of barriers to entry, see RICHARD WHISH, supra note 15, at pp. 46-48 and JONATHAN FAULL and ALI NIKPAY, supra note 19, at paras 1.43 et seq.

${ }^{125}$ Economists would generally take a more restricted view of what constitutes a barrier to entry than the Courts and Commission take. Matters characterised as "barriers" according to the Court might be framed as merely indicative of superior efficiency of the incumbent firm. See ROBERT H. BORK, supra note 26, at pp.310 et seq.; SARAH TURnBULL, "Barriers to Entry, Article 86 and the Abuse of a Dominant Position: An Economic Critique of European Community Competition Law" (1996) European Competition Law Review, Vol. 2, pp. 6-103.

${ }^{126}$ Case 22/78 Hugin Kassaregister AB v. Commission, supra note 62.

127 See e.g. Hilti AG v. Commission (supra note 113) and on appeal to the ECJ (supra note 73).
} 
(ii) Economies of scale have also been regarded as relevant in assessing the market power of a particular firm, ${ }^{128}$ as has the capital strength of the undertaking and its access to capital markets. ${ }^{129}$

(iii) The superior technology of a firm may also be considered, when assessing market power. ${ }^{130}$

(iv) Vertical integration is regarded as another important indicator of dominance. In United Brands, for instance, the ECJ described the extent to which the activities of the United Brands Company (UBC) were integrated and stated that this provided the investigated firm with commercial stability, which was a significant advantage over its competitors. ${ }^{131}$ In Hoffmann-La Roche, the Court pointed to Roche's highly developed sales network as a relevant factor conferring upon it a commercial advantage over its rivals. ${ }^{132}$

(v) Product differentiation has also been considered with regard to finding dominance. In that context, in United Brands, ${ }^{133}$ the ECJ deemed that the company's brand image (Chiquita bananas) and costly advertising campaigns were evident factors of dominance.

With regard to telecommunications, the Commission has provided guidance as to some concrete matters, which it is likely to consider as barriers to entry. These include: (i) whether an operator has privileged access to facilities, which cannot be reasonably duplicated within an appropriate time and the extent of the rights given operator has been granted by Member States' authorities; ${ }^{134}$ (ii) whether a given operator has dependent customers; and (iii) whether it owns intellectual property rights or holds confidential information concerning protocols or interfaces necessary to ensure inter-operability of software and hardware. ${ }^{135}$

The above list is however merely illustrative and by no means exhaustive. A compilation of all the factors that the Commission and the Courts may take into account in assessing dominance is indeed hardly possible. In view of our analysis of communications markets, we should however acknowledge explicitly the role that these other factors could play.

As stressed above, the nature of the electronic communications industry is such that market shares will be frequently not an appropriate gauge for assessing market power. Barriers to entry, on the other hand, will be a typical phenomenon in communications markets due to the high sunk costs, the network externalities and the inherent economies of scale. ${ }^{136}$ The

128 United Brands v. Commission, supra note 35.

129 See United Brands v. Commission, ibid. and Continental Can Co Inc. OJ [1972] L 7/25, [1972] CMLR D11.

${ }^{130}$ See e.g. United Brands and Hoffmann-La Roche, supra note 35; Case 322/81 Michelin v. Commission, supra note 44. This is an issue of certain controversy since a new firm wishing to enter the market will not face any greater cost than the alleged dominant firm, which has itself had to expend money and take risks in building up its technical know-how. Moreover, the newcomer may benefit if patents or knowhow of the allegedly dominant firm have fallen in the public domain.

$131 \mathrm{Ibid}$. at paras 69-81 and 85-90.

132 Ibid. at para. 48.

${ }^{133} \mathrm{Ibid}$. at paras 91-94.

134 Access Notice, at paras 74-75.

135 Guidelines on the application of EEC competition rules in the telecommunications sector, supra note 29, at paras 81-82.

${ }^{136}$ In the Microsoft decision, the Commission considered network effects as possible barriers to entry. It noted that, "[t]he network effects characterising the media software markets [...] translate into entry barriers for new entrants". See Case COMP/C3/37.792 Microsoft, supra note 74, at para. 420 (footnote omitted). 
importance of barriers to entry in communications is evident from the fact that they are the principal criterion for the assessment of the necessity of ex ante regulation pursuant to current EC regulatory regime, as we shall see below..$^{137}$

With regard to the assessment of significant market power conducted by the national regulatory authorities, the European Commission has indicated that, in addition to market shares, the market power of an undertaking can be measured according to the following criteria: (i) overall size of the undertaking; (ii) control of infrastructure not easily duplicated; (iii) technological advantages or superiority; (iv) absence of low countervailing buying power; (v) easy or privileged access to capital markets/financial resources; (vi) product/services diversification (e.g. bundled products or services); (vii) economies of scale; (viii) economies of scope; (ix) vertical integration; (x) a highly developed distribution and sales network; (xi) absence of potential competition; and (xii) barriers to expansion. ${ }^{138}$ A dominant position can derive from a combination of these criteria, "which taken separately may not necessarily be determinative". ${ }^{139}$ These criteria reflect the case law of the Commission and the Courts, as mentioned above and stress further the centrality of barriers to entry for assessing dominance in electronic communications markets.

\section{CONDUCT AND PERFORMANCE}

In determining dominance, the Court may additionally take into account the conduct of the firm, which is alleged to have abusive behaviour, notwithstanding the apparent circularity that this entails (in the sense that the conduct is used as a proof of the abusive conduct itself). In Michelin, for instance, the price discrimination of the company was deemed as an indicator of its dominance, even though the circularity involved thereby was explicitly noted by the Commission. ${ }^{140}$ In Eurofix-Bauco v. Hilti, the Commission regarded Hilti's behaviour as "witness to its ability to act independently of, and without due regard to, either competitors or customers...". ${ }^{141}$ In $A K Z O$, it found further that the undertaking's ability to weaken or eliminate troublesome competitors was an indicator of dominance. ${ }^{142}$

The economic performance of an undertaking may also be a factor indicating dominance. The fact that a firm had idle capacity, for instance, was regarded as significant in Hoffmann-La Roche. ${ }^{143}$ So was the ability of the undertaking to increase its prices, which the market subsequently followed, as found in Napier Brown-British Sugar. ${ }^{144}$

137 See infra Section 3.2.4.

${ }^{138}$ SMP Guidelines, at para. 78. All these criteria have been discussed by the European Regulators Group for electronic communications networks and services (ERG), which a forum of the National Regulatory Authorities and the European Commission. See ERG, Working Paper on the SMP Concept for the New Regulatory Framework, supra note 121 and Revised Working Paper on the SMP Concept for the New Regulatory Framework, ERG(03) 09rev1, October 2004.

139 SMP Guidelines, at para. 79.

140 Case 322/81 Michelin v. Commission, supra note 44.

${ }^{141}$ Eurofix-Bauco v. Hilti, OJ [1988] L 65/19, [1989] 4 CMLR 677, at para. 71.

142 ECS/AKZO OJ [1985] L 374/1, [1986] 3 CMLR 273, at para. 56, upheld on appeal Akzo Chemie BV v. Commission, supra note 44 , at para. 61.

${ }^{143}$ Hoffmann-La Roche, supra note 35.

144 Napier Brown-British Sugar, supra note 72. 
In communications, due to the strategies that market players develop in the pursuit of tipping markets and/or locking-in partners or consumers, an assessment of the conduct of the firm under scrutiny could be of importance. The Commission's decision in the Microsoft case is a recent proof in that regard. ${ }^{145}$

\subsubsection{A POSITION OF DOMINANCE WITHIN THE COMMON MARKET OR IN A SUBSTANTIAL PART OF IT}

Once the market has been defined and accordingly established that a firm has a dominant position on that market, one further question needs to be answered before turning to the issue of abuse. The question is whether the dominant position of the undertaking(s) under scrutiny is held "within the common market or in a substantial part of $i t^{\prime \prime}{ }^{146}$ It should be noted that this question is not the same as the delineation of the relevant geographical market. As discussed above, it is rather the equivalent of the de minimis doctrine under Article $81 \mathrm{EC}$, ${ }^{147}$ whereby "agreements of minor importanc" are excluded from the scope of Article 81(1) EC. ${ }^{148}$

In Suiker Unie v. Commission, the Court of Justice stated addressing this test under Article 82 EC that, "the pattern and volume of the production and consumption of the said product as well as habits and economic opportunities of vendors and purchasers must be considered". ${ }^{49}$ As the practice of the European Community Courts has shown, a Member State will almost always be deemed a substantial part of the common market and parts of a Member State, as established in Suiker Unie, can also be held "substantial". ${ }^{150}$ Indeed, very small markets were found to satisfy the "substantiality" test for the purposes of Article $82 \mathrm{EC}$, such as the port of Genoa $^{151}$ or the Frankfurt airport. ${ }^{152}$ Considering that communications cases will normally involve the provision of services or infrastructure over national, regional or multi-national networks, they will promptly fulfil the criterion of being dominant within the common market or a substantial part thereof.

\subsection{AbUSE: TyPeS OF ABUSIVE PRACTICES}

Once it has been decided that a firm has a dominant position in a substantial part of the common market, it is necessary to consider whether it has abused that position. Article 82 EC mentions as examples of such an abuse the imposition of unfair prices (Article 82(2)(a) EC);

145 Case COMP/C-3/37.792 Microsoft, supra note 74, at paras 638 et seq.

146 Article 82 EC (emphasis added).

147 RICHARD WHISH, supra note 15 , at p. 191.

148 The de minimis doctrine was established by the ECJ in Case 5/69 Völk v. Vervaecke [1969] ECR 295, [1969] CMLR 273. The Commission has published a number of Notices to that effect setting out the circumstances in which it considers an agreement of minor importance and thus not restricting competition to an appreciable extent. The latest notice was published at the end of 2001. See Commission Notice on agreements of minor importance, which do not appreciably restrict competition under Article 81(1) of the Treaty establishing the European Community (de minimis), OJ C 368/13, 22 December 2001, in particular at paras 7-9.

149 Cases 40/73 etc. Suiker Unie v. Commission [1975] ECR 1663, [1976] 1 CMLR 295, at para. 371.

$150 \mathrm{Ibid}$. With regard to the "southern part of Germany", at paras 445-448.

${ }^{151}$ Case C-179/90 Merci Convenzionali Porto di Genova v. Siderurgica Gabriella [1991] ECR I-5889, [1994] 4 CMLR 422.

152 Flughafen Frankfurt/Main, OJ [1998] L 72/30, [1998] 4 CMLR 779. 
limiting production, market or technical development (Article 82(2)(b) EC); discrimination (Article 82(2)(c) EC); and tying (Article 82(2)(d) EC). The given list is however far from being exhaustive. ${ }^{153}$ In fact, as we shall see below, Article $82 \mathrm{EC}$ has proved to be a multi-functional instrument addressing diverse situations framed as abuses of market power.

As mentioned at the outset of our analysis of Article $82 \mathrm{EC}$ as the instrument for controlling market power, dominance as such is not prohibited. However, the ECJ has pointed out in Michelin that a firm in a dominant position "has a special responsibility not to allow its conduct to impair undistorted competition on the common market". ${ }^{154}$ Examining the case law of the Community's Courts, it would in fact appear that this responsibility becomes greater, the greater the market power, so that a finding of abuse is more likely, where the firm under scrutiny is not merely dominant, but "enjoys a position of dominance approaching a monopoly". ${ }^{155}$ The latter scheme could be of particular significance for communications operators who tend to have substantial market shares due either to the remnants of exclusive or special rights 156 and/or to the network structure of the market and the resultant "winnertakes-all" scenarios. ${ }^{157}$

The abuse of dominant position is nonetheless not pre-determined by the mere finding of dominance, even one close to monopoly. From an economic perspective, if there are no entry barriers to the market in question, monopoly profits will in fact attract new market players, thus leading to increased, rather than lessened, competition in the long term. ${ }^{158}$ In an Article 82 analysis, one should consequently always recall the finding of the Court that, "[t]he concept of abuse is an objective concept relating to the behaviour of an undertaking in a dominant position $[\ldots]^{\prime \prime 159}$ and weigh this behaviour against the background of the concrete circumstances.

Since dominance is an objective concept, there is further no need of establishing causation between the firm's behaviour and the actual abuse. ${ }^{160}$ Intent is indeed not a defining element of Article 82 EC, albeit it might be required in certain types of abuse. ${ }^{161}$

Furthermore, it should be pointed out that Article 82 EC "catches" not only behavioural but also structural abuses of dominant position. The Court established the latter in the seminal

153 On the types of abuses caught by Article 82 EC, see JONATHAN FAULL and ALI NIKPAY, supra note 19, at paras 3.20 et seq.

${ }^{154}$ Case 322/81 Michelin v. Commission, supra note 44, at para. 57 (emphasis added). See also Case C-250/92 Gøttrup-Klim v. Dansk Landbrugs Grovvareselskab AmbA [1994] ECR I-5641, [1996] 4 CMLR 191, in particular at para. 49.

155 See para. 136 of the Opinion of AG Fennelly in Cases C-395/96 P etc. Compagnie Maritime Belge Transport SA and DafraLines v. Commission [2000] ECR I-1365, [2000] 4 CMLR 1076. Richard Whish formulates a concept of "super-dominance", when a firm has dominance nearing monopoly. See RICHARD WHISH, supra note 15, 2003, at pp. 189-190.

156 See Guidelines on application of EEC competition rules in the telecommunications sector, supra note 29.

157 See CARL SHAPIRO and HAL R. VARIAN, Information Rules, Boston, MA: Harvard Business School Press, 1999 , at pp. 177 et seq.

158 See supra note 124 on contestable markets.

159 Hoffmann-La Roche, supra note 35, at para. 91 (emphasis added).

160 See e.g. Continental Can, supra note 44 and Hoffmann-La Roche, supra note 35. On causation, see THOMAS EILMANSBERGER, "How to Distinguish Good from Bad Competition under Article 82 EC: In Search of Clearer and More Coherent Standards for Anti-Competitive Abuses" (2005) Common Market Law Review, Vol. 42, pp. 129-177, at pp. 140 et seq.

161 A finding of predatory pricing below average variable cost, for instance, does require the finding of intent. 
Continental $\mathrm{Can}^{162}$ judgment with regard to mergers, i.e. structural changes in the market and found them within the scope of Article 82 EC. Although since then, there has been only one other decision condemning a merger under Article 82 and mergers are now dealt with under the Merger Control Regulation, ${ }^{163}$ Continental Can remains the authority for the proposition that there is an abuse in altering the competitive structure of a market, where competition on the market is already weakened as a result of the very presence of the dominant undertaking in it. ${ }^{164}$ It is sufficient to demonstrate that the conduct is likely to produce such an effect or, as the Court put it in Commercial Solvents, that it "risks" producing it. ${ }^{165}$

The conduct of a dominant firm is deemed abusive if it has exploitative and/or anti-competitive effects. Exploitation suggests in broad terms the earning of monopoly profits at the expense of customers, while anti-competitive (or exclusionary) conduct is directed at competitors. ${ }^{166}$

Article 82 EC has been, in practice, far more regularly applied to behaviour, which the Commission or the Courts consider anti-competitive. ${ }^{167}$ Such cases are normally also the ones causing more controversy than those on exploitation, since the dominant firm will typically assert that it is simply competing - as it should 168 - whereas the complainant (or the Commission) will try to ascertain that the firm has departed from competition on the merits and is guilty of abusive behaviour against its competitors. The line between these two positions is often very fine, sometimes indiscernible. Most cases in the electronic communications sector will tend to fall under this controversial "on the line" category because of the multiplicity of factors at play. ${ }^{169}$

The following Sections will explore some types of abuse under Article 82 EC based on the case law of the Community Courts and the practice of the European Commission. Without the strict categorisation of exploitative and anti-competitive practices, which is in itself not always a clear-cut demarcation, ${ }^{170}$ the analysis will concentrate on refusal to supply (in particular, the essential facilities doctrine) and tying. This focused, rather than the extensive analysis of all Article 82 incompatible practices, will allow us to convey the complexity of issues when applying antitrust to communications markets in context and to assess antitrust's regulatory potential. The abusive pricing practices, ${ }^{171}$ although of particular interest in communications ${ }^{172}$

162 Continental Can v. Commission, supra note 44.

${ }_{163}$ Council Regulation (EC) 139/2004 on the control of concentrations between undertakings, supra note 22.

164 See also Hoffmann-La Roche, supra note 35, at paras 91 et seq.

165 Case 6 and 7/73 Commercial Solvents Corp v. Commission, supra note 31, at para. 25.

${ }^{166}$ In Continental Can (supra note 44, at para. 26) the Court made it clear that Article 82 EC "is not only aimed at practices, which may cause damage to consumers directly, but also at those which are detrimental to them through their impact on an effective competition structure". For a comprehensive analysis, see ELEANOR M. FOx, "What is Harm to Competition? Exclusionary Practices and Anticompetitive Effect" (2002) Antitrust Law Journal, Vol. 70, pp. 371-411 and "We Protect Competition, You Protect Competitors" (2003) World Competition, Vol. 26, No 2, pp. 159-165.

167 JONATHAN FAULL and ALI NIKPAY, supra note 19, at para. 3.22.

168 See e.g. Case T-228/97 Irish Sugar plc v. Commission [1999] ECR II-2969, [1999] 5 CMLR 1300, at para. 112.

${ }^{169}$ As a recent example, see Case COMP/C-3/37.792 Microsoft, supra note 74. See infra the following Sections.

170 See e.g. RICHARD WHISH, supra note 15, at pp. 194-195.

${ }^{171}$ A collective term that essentially refers to excessive, predatory, discriminatory pricing and price squeeze. On excessive pricing, see Access Notice, at paras 106-109. On predatory pricing, see Access Notice, at paras 110-116. For a recent example from the network-bound sectors, see Commission Decision 2001/354, Deutsche Post, OJ L 125/27, 5 May 2001, [2001] 5 CMLR 99, at 
(especially for economists, if not always for lawyers), will regrettably remain out of the scope of the current work, while the concepts of complex dominance will only be elaborated upon in context.

\subsubsection{REFUSAL TO SUPPLY}

Firms that are not dominant are generally free to choose for themselves the parties with whom they wish to enter in contractual relations. Freedom of contract is indeed a basic rule of the free market economy. ${ }^{173}$ In the case of dominant undertakings, however, that freedom may be curtailed and a refusal to deal may constitute an abuse of dominance if this weakens competition in the particular market. ${ }^{174}$ There are three basic scenarios involving refusal to supply, namely: (i) a withdrawal of supply of an existing customer; (ii) a refusal to supply a new customer; and derivative from the latter (iii) a refusal to grant access to an essential facility. ${ }^{175}$

The refusal to supply an existing customer as a classic set-up was first established as an abuse in the Commercial Solvents judgment. ${ }^{176}$ There the Court upheld the Commission's decision ${ }^{177}$ that Commercial Solvents, a US undertaking, had abused its dominant position by refusing to supply aminobutanol to Zoja, an Italian pharmaceutical company, which needed the substance for the production of a certain anti-tuberculosis drug. Commercial Solvents was not only the dominant supplier of aminobutanol but its refusal to supply also coincided with the emergence of its own subsidiary, ICI, on the downstream market for anti-TB drugs. Thus, "the anti-competitive aspect of Commercial Solvents' behaviour was particularly clear where the refusal to supply would eliminate the only serious competitor that ICI would face in the downstream market" ${ }^{178}$ In its judgment, the Court of Justice ascertained that it was an abuse to refuse to supply an existing customer, who would be, as a result, eliminated from the downstream market. ${ }^{179}$

para. 35 and Case T-175/99 UPS Europe SA v. Commission [2000] ECR II-1915, [2002] 5 CMLR 67. For an extensive analysis of Deutsche Post, see DAVID E. M. SAPpington and J. GRegory SIDAK, "Competition Law for State-Owned Enterprises" (2003) Antitrust Law Journal, Vol. 71, pp. 779-523, at pp. 485 et seq. On price discrimination, see Access Notice, at paras 121-122 and 125126. On price squeeze, see Access Notice, at paras 117-119.

172 Improper allocation of costs and interference with transfer pricing could in fact occur often in the communications industry, where firms are normally active in more than one market. The monopolistic past of the sector is also a factor to be considered in this context.

173 See ADAM SMITH, An Enquiry into the Nature and Causes of the Wealth of Nations, New York: Modern Library, 1937 (first published 1776), available at $<$ http://www.gutenberg.org/etext/3300>.

174 JONATHAN FAULL and ALI NIKPAY, supra note 19, at paras 3.149 et seq.

175 For the relevant scenarios in the field of access agreements, as identified by the Commission, see Access Notice, at para. 84. The fourth possible scenario of refusal to supply, where the undertaking does not deal with one customer, while dealing with other, falls under discrimination as type of abuse.

176 Case 6 and 7/73 Commercial Solvents Corp v. Commission, supra note 31.

177 Zoja/CSC-ICI, OJ [1972] L 299/51, [1973] CMLR D50 (text not available in English).

178 See RICHARD WHISH, supra note 15, at p. 664.

179 The Court stated that, "an undertaking which has a dominant position on the market in raw materials and which, with the object of reserving such raw material for manufacturing its own derivatives, refuses to supply a customer, which is itself a manufacturer of these derivatives, and therefore risks eliminating all competition on the part of this customer, is abusing its dominant position within the meaning of Article 86 [now 82 EC]“. See Case 6 and 7/73 Commercial Solvents Corp v. Commission, supra note 31 , at para. 25. 
The Court articulated further that only objective grounds could justify a refusal to supply an existing customer. This principle was affirmed in a line of subsequent cases, inter alia, by United Brands ${ }^{180}$ and Télémarketing. ${ }^{181}$ In the latter, the Court extended the scope of refusal to supply to services 182 as well, and stated that, "an abuse within the meaning of Article 86 [now $82 \mathrm{EC}]$ is committed where, without any objective necessity, an undertaking holding a dominant position on a particular market reserves to itself or to an undertaking belonging to the same group of ancillary activity which might be carried out by another undertaking as part of its activities upon a neighbouring but a separate market, with the possibility of eliminating all competition from such undertaking“. ${ }^{183}$

In addition to the above constellations of refusal to supply a raw material ${ }^{184}$ and services, ${ }^{185}$ pursuant to the case law of the Community Courts, a refusal to supply as a technique for dividing markets; ${ }^{186}$ a refusal to supply spare parts, ${ }^{187}$ a refusal to supply proprietary information, ${ }^{188}$ as well as, under some exceptional circumstances, ${ }^{189}$ a refusal to license intellectual property rights ${ }^{190}$ were held an abuse of dominance under Article 82 EC. It is only under specific conditions that a refusal to supply a new customer (as supposed to existing ones) will qualify as an abuse. Exceptions are nonetheless possible, where, for instance, such a refusal is based on the nationality of the customer ${ }^{191}$ or in the case of essential facility, as we shall see below.

180 United Brands, supra note 35. In this case, the Court condemned a producer of bananas for his refusal to supply Olesen, a distributor who had participated in an advertising campaign by one of the competitors of United Brands. Interestingly, it was not effectively proven that Olesen would be eliminated from the market.

${ }^{181}$ Case 311/84 CBEM v. CLT and IPB (Télémarketing), supra note 30. Télémarketing was a case where an undertaking that dominated the market for television advertising stopped accepting spot advertisements that indicated a telephone number to be used by the public to obtain further information, unless the number given for Belgium was that of its own subsidiary specialised in providing such telemarketing services. In Télémarketing, the Court confirmed the Commercial Solvents judgment and held, notably that it could also apply to "a service which is indispensable for the activities of another undertaking on another market". Ibid. at para. 26 (emphasis added).

182 Ibid. at para. 26.

183 Télémarketing, ibid. at para. 27. "Objective necessity" could be, for instance, found to exist, when the undertaking in dominant position refuses to supply a customer from whom payment is overdue (see e.g. Leyland DAT v. Automotive Products [1994] 1 BCLC 245 (CA)). If a dominant undertaking refuses to supply in response to a competitive challenge, its response must be fair and proportional to the threat. It cannot thus withdraw all its supplies immediately from a long-standing customer only because that customer has become associated with a competitor (see e.g. BBI/Boosey \& Hawkes, OJ [1987] L 286/36, [1988] 4 CMLR 67). Finally, commercial justification for a policy will not necessarily constitute an objective justification such as to avoid a finding of abuse, as was the case in Télémarketing.

${ }^{184}$ See Commercial Solvents, supra note 31. See also Napier Brown-British Sugar, supra note 72.

185 Télémarketing, supra note 30.

${ }^{186}$ Case 226/84 British Leyland v. Commission, supra note 62.

187 Hugin Kassaregister, supra note 62.

188 See e.g. Decca Navigation System, supra note 62.

189 See infra the following Section.

${ }^{190}$ Case T-69/89 Radio Telefis Eireann v. Commission v. Commission [1991] ECR II-485, [1991] 4 CMLR 586; Case T-70/89 BBC Enterprises Ltd v. Commission [1991] ECR II-535, [1991] 4 CMLR 669; Case T-76/89 Independent Television Publications v. Commission [1991] ECR II-575, [1991] 4 CMLR 745; Joined Cases C-241/91 P and C-242/91 P RTE and ITP v. Commission (Magill) [1995] ECR I743; Case C-481/01 IMS Health GmbH \& Co v. NDC Health GmbH \& Co KG [2004]; Case COMP/C-3/37.792 Microsoft, supra note 74.

191 See e.g. Case 7/82 GVL v. Commission [1983] ECR 483, [1983] 3 CMLR 645. 


\subsubsection{THE ESSENTIAL FACILITIES DOCTRINE}

\subsubsection{THE CONCEPT OF ESSENTIAL FACILITIES AND THE EC LEGAL DOCTRINE}

The concept of essential facilities and its application as a means of controlling market power has been clarified in some telecommunications-specific soft law instruments. Both the Access Notice (adopted under the 1998 communications regime) and the Commission SMP Guidelines (adopted under the 2002 framework for electronic communications networks and services) provide insightful and useful guidance. Bizarrely, while the Access Notice stresses the potential significance of the essential facilities doctrine for the communications sector that "will in many cases be of relevance in determining the duties of dominant TOs [Telecommunication Operators]", 192 the SMP Guidelines suggest precisely the opposite. ${ }^{193}$ This peculiar divergence is due to the fact, as admitted by the SMP Guidelines, that in the electronic communications sector "essential-facilities-like" situations will normally presently be dealt with under the ex ante specific regulation rather than under general competition law. ${ }^{194}$

This only enhances the importance of our discussion of the essential facilities doctrine, since, if competition law were to be the sole regulator of the communications sector, it would have to address ex post such essential facilities situations in a sufficiently effective manner. In this context, the following paragraphs will elaborate upon the essential facilities doctrine in European Community law and figure out its mechanism and possible application to ecommunications markets as a tool of control of market power and of access to bottleneck situations. Since access issues in the communications sector are recurrent and not occasional, ${ }^{195}$ the potency of this intervention could indeed be critical.

The refusal to grant access to an essential facility is a central concept within the broader category of "refusal to supply" and the antitrust theory, which developed with regard to it, is known as the essential facilities doctrine (EFD). Before examining this (more or less) established doctrine in the law of the European Community, ${ }^{196}$ it is helpful to see what is (or might constitute) such an essential facility. Colloquially, the term suggests access to a physical

192 Access Notice, at para. 68.

193 SMP Guidelines, at paras 81-82.

194 Ibid.

195 Bernard Amory and AleXANDre Verheyden, “Article 82 (ex 86): Fair and Efficient Terms of Access to 'Bottleneck' Network Facilities?" in Claus Dieter EhlermanN and LOUISA Gosling (eds.), European Competition Law Annual 1998: Regulating Telecommunications, Oxford/Portland, Oregon: Hart Publishing, 2000, pp. 67-83.

196 On the essential facilities doctrine, see inter alia KATHERINE SCHINDLER, Wettbewerb in Netzen als Problem der kartellrechtlichen Missbrauchaufsicht: Die "Essential Facility"-Doktrin im amerikanischen, europäischen und schweizerischen Kartellrecht, Berne/Frankfurt/Brussels: Peter Lang, 1998; ABBOTT B. LIPSKY, JR. and J. GREGORY SIDAK, “Essential Facilities" (1999) Stanford Law Review, Vol. 51, pp. 1187-1249; JERRY A. HAUSMAN and J. GREGORY SIDAK, "A Consumer-Welfare Approach to the Mandatory Unbundling of Telecommunications Networks" (1999) The Yale Law Journal, Vol. 109, pp. 417-505; BARRY DOHERTY, "Just What Are Essential Facilities?" (2001) Common Market Law Review, Vol. 38, pp.397-436; ROBERT PITOFSKY, DONNA PATTERSON and JONATHAN HOOKS, "The Essential Facilities Doctrine under US Antitrust Law" (2002) Antitrust Law Journal, Vol. 70, pp. 443-462; DAMIEN GERADIN, "Limiting the Scope of Article 82 EC: What Can the EU Learn from the US Supreme Court's Judgment in Trinko in the Wake of Microsoft, IMS and Deutsche Telekom" (2004) Common Market Law Review, Vol. 41, pp. 1519-1553; CYRIL RITTER, “Refusal to Deal and 'Essential Facilities': Does Intellectual Property Require Special Deference Compared to Tangible Property?" (2005) World Competition, Vol. 28, No 3, pp. 281-298. 
infrastructure, such as port, airport, pipeline or cable network, ${ }^{197}$ where due to its physical characteristics access thereto is somehow limited but essentially needed. The term has been however used to signify, as will be shown below, not only physical, but also other structures and/or constellations. As a general definition capable of matching different real life situations, it could be thus appropriate to use the definition given by Massimo Motta. He suggests that, "[a]ny input which is deemed necessary for all industry participants to operate in a given industry and which is not easily duplicated might be seen as an essential facility". ${ }^{198}$

The essential facilities doctrine originates from US antitrust. ${ }^{199}$ In the European Community context, there have been a number of cases subsumed under it ${ }^{200}$ but the doctrine is not unequivocal, both in the US201 and in the EC.202 In EC law, it could be argued that the EFD stems from the approach of the Court of Justice in Hoffmann-La Roche, categorising as abusive conduct, which "has the effect of hindering the maintenance of the degree of competition still existing in the market or the growth of that competition". ${ }^{203}$ It can also be discerned in subsequent judgments of the ECJ and CFI such as Télémarketing ${ }^{204}$ and Magill. ${ }^{205}$ Richard Whish suggests that the EFD should not be viewed as an independent doctrine but rather as evolved from the principle elaborated in Commercial Solvents, where, as commented above, the refusal to supply a competitor in a downstream market, where the effect of doing so would be to eliminate all competition in the downstream market, was deemed an abuse of Article 82 EC. ${ }^{206}$ Indeed, some judgments typically labelled as essential facility ones, such as Oscar

\footnotetext{
197 RICHARD WHISH, supra note 15, at p. 666.

${ }^{198}$ MAssimo MotTA, Competition Policy: Theory and Practice, Cambridge: Cambridge University Press, 2004, at p. 66 (emphasis in the original).

199 United States v. Terminal Railroad Association, 224 US 383 (1912). Other major cases in US antitrust developing the essential facilities doctrine are Eastman Kodak Co v. Southern Photo Materials Co, 273 US 359 (1927); Lorain Journal Co v. United States, 342 US 143 (1951); Otter Tail Power Co v. United States, 410 US 366 (1973); Aspen Skiing Co v. Aspen Highlands Skiing Corp, 472 US 585 (1985); Eastman Kodak Co $v$. Image Technical Services Inc., 504 US 451 (1992). The leading case that applied the EFD in the telecommunications industry shortly before the AT\&T divesture was MCI Communications Corp v. ATET, 708 F.2d 1081, 1132-33 ( $7^{\text {th }}$ Circuit 1983). For an excellent overview of the origins and development of the EFD in US antitrust, see ABBOTT B. LIPSKY, JR. and J. GREGORY SIDAK, “Essential Facilities" (1999) Stanford Law Review, Vol. 51, pp. 1187-1249, at pp. 1195 et seq. See also ROBERT PITOFSKY, DONNA PATTERSON and JONATHAN HOOKS, supra note 196, at pp. 445 et seq.; BARRY DOHERTY, supra note 196, at pp. 398 et seq.

200 See e.g. JoHn Temple LANG, "Defining Legitimate Competition: Companies' Duty to Supply Competitors and Access to Essential Facilities" (1994) Fordham Law Journal, Vol. 18, pp. 437 et seq. See also Case C-7/97 Oscar Bronner GmbH \& Co KG v. Mediaprint Zeitungs- und Zeitschriftenverlag GmbH \& Co KG etc. [1998] ECR I-7791, [1999] 4 CMLR 112, Opinion of Advocate General Jacobs, at paras 35 et seq.

201 There is a line of critique against the US EFD. See e.g. PHILIP E. AREEDA, "Essential Facilities: An Epithet in Need of Limiting Principles" (1990) Antitrust Law Journal, Vol.58, pp. 841 et seq.; DONALD BAKER, "Compulsory Access to Network Joint Ventures under the Sherman Act: Rules or Roulette?" (1993) Utah Law Review, Vol. 4, pp. 999-1019; EINER ElHAUGE, "Defining Better Monopolization Standards" (2003) Stanford Law Review, Vol. 56, pp. 253-344. The Supreme Court did in fact expressly refer to the Areeda's article in the case of Trinko (Verizon Communications Inc v. Law Offices of Curtis V. Trinko, LLP, 540 US 682 (2004)), which limited the EFD and distinguished the case from the classical Aspen Skiing Co v. Aspen Highlands Skiing Corp (supra note 199).

202 DAMIEN GERADIN, supra note 196; CYRIL RITTER, ibid.

${ }^{203}$ Hoffmann-La Roche, supra note 35, at para. 44.

204 Télémarketing, supra note 30.

${ }^{205}$ Case T-69/89 RTE v. Commission; Case T-70/89 BBC v. Commission and Case T-76/89 ITP v. Commission, upheld on appeal Joined Cases C-241/91 P and C-242/91 P RTE and ITP v. Commission, all supra note 190.

${ }^{206}$ See RICHARD WHISH, supra note 15, at p. 664 and pp. 667 et seq.
} 
Bronner, ${ }^{207}$ do not necessarily refer to the doctrine and the Court of Justice has not yet relied upon it in an explicit manner. The European Commission however has.

The Commission used explicitly the concept of essential facility for the first time with regard to harbour (i.e. physical) infrastructure in Sea Containers v. Stena Sealink and defined it for the purposes of the case as "a facility or infrastructure, without access to which competitors cannot provide services to their customers" ${ }^{208}$ In that very EFD first case, the Commission dealt with a complaint against Sealink - a company that owned and operated the Holyhead port in Northern Wales, providing also a ferry service to and from Ireland. B\&I was a rival ferry operator and claimed that Sealink had organised the port's sailing schedules in such a manner that caused maximum disruption to B\&I's services, while giving advantage to Sealink. The Commission found ultimately that there was a prima facie case of abuse. ${ }^{209}$ It held that, "[a]n undertaking which occupies a dominant position in the provision of an essential facility and itself uses that facility [...] and which refuses other companies access to that facility without objective justification or grants access to competitors only on terms less favourable than those which it gives its own services, infringes Article 86 [now 82 EC]“. ${ }^{210}$ The Commission's decision was (unfortunately) not appealed before the Court of First Instance but its importance as the first application of the essential facilities doctrine remains considerable. ${ }^{211}$

Subsequently, the Commission adopted a number of decisions dealing with physical essential facilities, in particular harbour facilities ${ }^{212}$ and some air transport related ones. ${ }^{213}$ An important follow-up of these EFD-based decisions, although in rather different domain, namely intangible intellectual property rights, is the Magill case. ${ }^{214}$ In the latter, the Commission considered that three major television broadcasters in Ireland held dominant positions on the markets for the supply of their programme listings (which were copyright protected). The companies refused to supply the content of their programme listings to other magazines more than a day in advance. Essentially, this made it impossible for independent publishers to produce a weekly magazine covering all TV and radio programmes. The Commission condemned the behaviour of the broadcasters as an abuse of dominance and ordered compulsory licensing in favour of the independent weekly TV magazine Magill. The decision was confirmed by both the Court of First Instance ${ }^{215}$ and the Court of Justice..$^{216}$

207 Oscar Bronner, supra note 200. Advocate General Jacobs does however refer to the EFD. So do the parties to the case.

${ }^{208}$ Sea Containers v. Stena Sealink - Interim Measures, OJ [1994] L 15/8, [1995] 4 CMLR 84, at para. 41. The Access Notice (at para. 68) defines an essential facility as "a facility or infrastructure which is essential for reaching customers and/or enabling competitors to carry on their business, and which cannot be replicated by any reasonable means".

${ }^{209}$ Sea Containers v. Stena Sealink, ibid. at para. 78. Although in fact the interim measures against Stena Sealink Line and Stena Sealink Ports were rejected because Sealink had in the meantime made an offer to Sea Containers, which enabled it to use the slot times, which it regarded as essential for the operation of a commercially viable service (ibid. at paras 79 et seq.).

210 Sea Containers v. Stena Sealink, ibid. at para. 66.

211 PAUL NiHOUL and PETER RODFORD, supra note 4, at para. 4.331.

212 See Port of Rødby, OJ [1994] L 55/52, [1994] 5 CMLR 457; Porto di Genova, OJ [1997] L 301/27; XXVI Report on Competition Policy, 1996, at paras 131-132.

${ }^{213}$ See e.g. London European-Sabena, OJ [1988] 317/47 and Flughafen Frankfurt am Main AG, OJ [1998] L 72/30.

${ }^{214}$ Magill TV Guide/ITP, BBC, RTE, supra note 62.

${ }^{215}$ See supra note 190. 
The European Court of Justice stated that, "the refusal by the owner of an exclusive right to grant a licence, even if it is the act of an undertaking holding a dominant position, cannot in itself constitute abuse of a dominant position". ${ }^{217}$ It added however that, "the exercise of an exclusive right by the proprietor may, in exceptional circumstances, involve abusive conduct". ${ }^{218}$

There were three sets of exceptional circumstances identified in Magill: (i) Firstly, the Court of Justice underlined that the dominant undertakings' refusal prevented the appearance of a new product, which the dominant undertakings did not offer and for which there was a potential consumer demand. As such, the refusal was inconsistent in particular with Article 82(2)(b) of the Treaty, which provides that an abuse may consist in "limiting production, markets or technical development to the prejudice of consumers". ${ }^{219}$ (ii) Secondly, along the lines of Commercial Solvents, ${ }^{220}$ the Court pointed out that the conduct at issue enabled the dominant undertakings to reserve "to themselves the secondary market of weekly television guides by excluding all competition on that market". ${ }^{221}$ (iii) Thirdly, the refusal was not objectively justified. This strict test was more recently confirmed in the IMS Health judgment ${ }^{222}$ (although it remains an open issue whether indeed the list of exceptional circumstances is exhaustive).223

Against the background of the above sketched decisions and despite the relatively stringent test of Magill as far as intellectual property rights are concerned, it might appear that the EFD is a rather convenient way of receiving supply from a dominant undertaking. ${ }^{224}$ As has however been proven by the Courts' later judgments and as we shall see in the following paragraphs, the essential facilities doctrine is nothing similar to a self-executing formula, granting access to third parties under all circumstances.

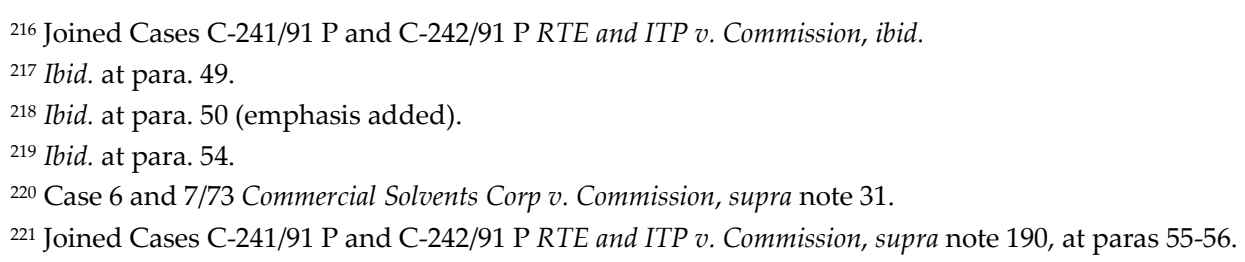

222 See supra note 190. On the IMS Health case, see e.g. EsTELLE DeRCLAYE, “The IMS Health Decision: A Triple Victory" (2004) World Competition, Vol. 27, pp. 397 et seq.; Estelle DeRCLAYE, "The IMS Health Decision and the Reconciliation of Copyright and Competition Law", (2004) European Law Review, Vol. 29, pp. 87 et seq.; VASSILIS HatZOPOUlOS, "Case Law of the Court of Justice: Case C-418/01 IMS Health GmbH v. NDC Health GmbH, Judgment of the Fifth Chamber of 29 April 2004“ (2004) Common Market Law Review, Vol. 41, pp. 1613-1638; DonNA M. GITTER, "Strong Medicine for Competition Ills: The Judgment of the European Court of Justice in the IMS Health Action and its Implications for Microsoft Corporation" (2005) Duke Journal of Comparative and International Law, Vol. 15, pp. 153-192.

${ }^{223}$ In Microsoft, which is the latest case dealing with refusal to supply intellectual property rights (supra note 74, in particular at paras 546-791), although the Commission did follow the Magill test, it stated (rather confusingly) that, "there is no persuasiveness to an approach that would advocate the existence of an exhaustive checklist of circumstances of exceptional character that may deserve to be taken into account when assessing a refusal to supply" (ibid. at para. 555). It is also noteworthy that in applying the test, the Commission did not pay sufficient attention to the "new product" criterion. See DAMIEN GERADIN, supra note 196, at pp. 1532 et seq. and the arguments of Microsoft expressed in its appeal and application for interim relief (supra note 74$)$.

${ }^{224}$ In fact, the Magill judgment has been subject to much criticism. For an interesting view, see JAMES TURNEY, "Defining the Limits of the EU Essential Facilities Doctrine on Intellectual Property Rights: The Primacy of Securing Optimal Innovation" (2005) Northwestern Journal of Technology and Intellectual Property, Vol. 3, No 2, pp. 179-202, at pp. 193 et seq. Turney suggests that the decision of the Court was based on the particular facts of the concrete case concerning the copyright protected TV programme listings and the Court was sceptical about the existence of copyright on such TV listings (which were "unworthy" of protection). Indeed, the UK and Irish copyright laws were the only ones EU-wide that allowed for TV listings to be copyright protected. 
The judgment of the CFI in Tiercé Ladbroke, 225 a case concerning the Belgian horse betting market, 226 indicated the need for clearer limits in the application of the essential facilities doctrine. Although the Court of First Instance agreed in principle that essential resources must be shared, it pointed out that a refusal to supply could not fall within the prohibition of Article 82 EC "unless it concerned a product or a service which was either essential for the exercise of the activity in question, in that there was no real substitute, or was a new product whose introduction might be prevented, despite specific, constant and regular potential demand on the part of the consumers...".227

The seminal judgment of Oscar Bronner v. Mediaprint Zeitungs- und Zeitschriftenverlag 228 confirmed the trend set in Ladbroke for defining the limits of the EFD and for developing a clearer, stricter test. The facts of that particular case brought before the ECJ for a preliminary ruling under Article 234 EC were that Oscar Bronner, a publisher of the newspaper "Der Standard" desired to have access to the highly developed home-delivery distribution system of its much larger competitor, Mediaprint. Bronner complained that a refusal to grant such an access amounted to an infringement of the Austrian analogue of Article 82 EC. He argued further that, "postal delivery, which generally does not take place until the late morning, does not represent an equivalent alternative to home-delivery, and that, in view of its small number of subscribers, it would be entirely unprofitable for it to organise its own home-delivery system". ${ }^{229}$

On the question of whether access to the distribution system of Mediaprint could be considered essential (or "indispensable", in the language of the judgment) the ECJ stated that, "[i]t should be emphasised in that respect that, in order to demonstrate that the creation of such a system is not a realistic potential alternative and that access is indispensable, it is not enough to argue that it is not economically viable by reason of the small circulation of the daily newspaper or newspapers to be distributed. For such an access to be capable of being regarded as indispensable, it would be necessary at the very best to establish [...] that it is not economically viable to create a second home-delivery scheme for the distribution of daily newspapers with a circulation comparable to that of the daily newspapers distributed by the existing scheme" ${ }^{230}$

Thus, in order for a facility such as the Mediaprint's home delivery scheme to be essential, it does not suffice that such a scheme exceeds the economic capacity of a smaller competitor (such as Bronner). The ECJ had in effect raised the threshold for economic viability farther away from the subjective position of the complainant, (beyond the notion of "objective

${ }^{225}$ Case T-504/93 Tiercé Ladbroke v. Commission, supra note 44.

${ }_{226}$ The case concerned a Commission's rejection of a complaint by the leading operator in the Belgian horse betting market against the refusal by an undertaking holding the video and audio rights to horse races in France to license these rights for use by Ladbroke's betting shops in Belgium.

227 Tiercé Ladbroke v. Commission, supra note 44, at para. 131 (emphasis added).

228 Bronner, supra note 200.

229 Bronner, ibid. at para. 8.

${ }^{230}$ Bronner, ibid. at paras 45 and 46 (emphasis added). The narrow definition of essentiality as made in Bronner was reaffirmed by the IMS Health judgment (supra note 190, in particular at paras 28-29). 
competitor" found in European Night Services ${ }^{231}$ ) towards a standard of an objective competitor comparable in size to the holder of the alleged essential facility. To use the words of Advocate General Jacobs, "[i]t seems [...] that intervention of that kind [granting access], whether understood as an application of the essential facilities doctrine or, more traditionally, as a response to a refusal to supply goods or services, can be justified in terms of competition policy only in cases in which the dominant undertaking has a genuine stranglehold on the related market. That might be the case for example where duplication of the facility is impossible or extremely difficult owing to physical, geographical or legal constraints or is highly undesirable for reasons of public policy. It is not sufficient that the undertaking's control over a facility should give it a competitive advantage" ${ }^{\prime 232}$

The Access Notice, although adopted before the actual Bronner judgment, ${ }^{233}$ follows the above stringent test and suggests that in order to determine whether access to a facility should be ordered under the competition rules, the following elements, taken cumulatively, should be considered:

(i) whether access to the facility in question is generally essential in order for companies to compete on that related market. In this regard, it will not be sufficient that the position of the company requesting access would be more advantageous if access were granted - but refusal of access must lead to the proposed activities being made either impossible or seriously and unavoidably uneconomic;

(ii) whether there is sufficient capacity available to provide access;

(iii) whether the facility owner fails to satisfy demand on an existing service or product market, blocks the emergence of a potential new service or product, or impedes competition on an existing or potential service or product market;

(iv) whether the company seeking access is prepared to pay the reasonable and nondiscriminatory price and will otherwise in all respects accept non-discriminatory access terms and conditions; and

(v) whether there is no objective justification for refusing to provide access. Such a justification could include an overriding difficulty of providing access to the requesting company, or the

${ }^{231}$ In European Night Services the Court stated that, "neither the parent undertaking nor the joint venture thus set up may be regarded as being in possession of infrastructure, products or services which are 'necessary' or 'essential' for entry to the relevant market unless such infrastructure, products or services are not 'interchangeable' and unless, by reason of their special characteristics - in particular the prohibitive cost of and/or time reasonably required fro reproducing them - there are no viable alternatives available to potential competitors of the joint venture, which are thereby excluded from the market". See Cases T-374, T-375, T-384 and T-388/94 European Night Services v. Commission [1998] ECR II-3141, [1998] 5 CMLR 718.

232 Bronner, supra note 200, AG Jacobs Opinion, at para. 65 (emphasis added). Pierre Larouche point out that, even though none of the Courts has developed its reasoning as far, one could conclude that upon Bronner a two-pronged test in order to determine whether a facility is essential emerged: (i) on the basis of relevant market analysis, lack of access to a facility such as the alleged essential facility must have an effect on competition on the relevant market ("interchangeability" prong) and (ii) it must not be economically viable for an "objective competitor" comparable in size to the holder of the alleged essential facility to replicate or duplicate the actual facility in question ("viable alternative" prong). See PIERRE LAROUCHE, supra note 8, at pp. 193196.

233 The judgment of the Court is of 26 November 1998, the AG Jacobs Opinion of 28 May 1998, while the Access Notice was published in the Official Journal on 22 August 1998. 
need for a facility owner, which has undertaken investment aimed at the introduction of a new product or service to have sufficient time and opportunity to use the facility in order to place that new product or service on the market. ${ }^{234}$

\subsubsection{OBSERVATIONS ON THE EFD AND ITS APPLICATION}

Against the backdrop of the above case law and practice of the Community institutions, it seems that the hopes of the proponents of the use of competition law for control of market power and access in network sectors through application of the essential facilities doctrine have been dashed. The Bronner judgment in particular, interpreted the latter doctrine fairly restrictively and thus lent further credence to the argument that competition law on its own is insufficient to deal with complex access issues. ${ }^{235}$ Even though the standard of assessment is not as high as genuine monopoly, as suggested by Lipsky and Sidak, ${ }^{236}$ the essential facilities doctrine may not be relied upon as a universal solution for questions involving access, especially in the light of the technological advances in the communications sector, which make the duplication of facilities more feasible.

Even if the facilities in question are indeed "bottlenecks", allowing the owner or operator to exercise "a genuine stranglehold" 237 over the market, issues of access to such facilities raise complex pricing issues. Generic competition law offers little guidance on such issues and there is a need for specialised regulatory intervention in order to determine the "fair" access prices. In fact, this "dark" side of the application of the EFD was already stressed upon by Advocate General Jacobs in his Bronner Opinion. In paragraph 69 thereof, he suggested that, "[t]o accept Bronner's contention would be to lead the Community and national authorities and courts into detailed regulation of the Community markets, entailing the fixing of prices and conditions for supply in large sectors of the economy. Intervention on that scale would not only be unworkable but would also be anti-competitive in the longer term and indeed would scarcely be compatible with a free market economy". ${ }^{238}$

Although the focus of his argumentation was different, Advocate General Jacobs acknowledged nonetheless the need of "regulating" after access had been granted under the EFD. The measure of just compensation for mandatory access is in itself not unproblematic. It

${ }^{234}$ Access Notice, at para. 91. The test of the Access Notice follows closely the test developed under US antitrust, where in order to establish liability under the essential facilities doctrine, a party must prove four factors: "(1) control of the essential facility by a monopolist; (2) competitor's inability practically or reasonably to duplicate the essential facility; (3) the denial of the use of the facility to a competitor; and (4) the feasibility of providing the facility to competitors". See MCI Communications Corp v. ATET, supra note 199.

235 Piet Jan Slot and ANDrew SkUdder, "Common Features of Community Law Regulation in the Network-Bound Sectors" (2001) Common Market Law Review, Vol. 38, No 1, pp. 93-97. See also LeIGH HANCHER, "Case Law of the Court of Justice: Case C-7/97 Bronner v. Mediaprint [1998] ECR I-7791“ (1999) Common Market Law Review, Vol. 36, 1999, pp. 1289-1307.

${ }^{236}$ Lipsky and Sidak pointed out that, "...where the owner of the facility has no monopoly power, there is no basis for antitrust intervention of any kind. The standard for identification of an 'essential facility' should be at least as stringent as the standard of proof of monopoly power". ABBOTT B. LIPSKY, JR. and J. GREGORY SIDAK, supra note 199, at p. 1220. See also ROBERT PITOFSKY, DONNA PATTERSON and JONATHAN HOOKS, supra note 196, at p. 450.

237 As formulated by the AG Jacobs in his Bronner opinion, supra note 232.

${ }^{238}$ AG Jacobs Opinion, Bronner, ibid. at para. 69. 
must essentially mimic "the outcome of voluntary exchange" 239 and this could be, from economic point of view, a fairly complex task. ${ }^{240}$ Although it is presently agreed upon that the TELRIC (total element long-run incremental cost) provides a good basis, ${ }^{241}$ there is in practice considerable disagreement over its correct measurement, the correct measurement of and the time horizon of the forward-looking common costs, as well as over the correct method for determining the share of the common costs that may be reasonably recovered in the price for the particular unbundled network element. ${ }^{242}$

Beyond the complexity of calculating the access price, ${ }^{243}$ the mere "[r]ecognition that the essential facilities doctrine, where properly applicable, requires extensive judicial regulation of monopoly conduct raises important policy and even constitutional questions“. ${ }^{244}$ Since it is certainly not for the judges to regulate.

Finally, the application of the EFD should be viewed in its relationship with broader antitrust policy. ${ }^{245}$ In the pursuit of consumer welfare, the competition authorities and the Courts should not simply apply the EFD case law but carefully balance the interests of the parties involved, especially in industries where innovation is crucial and the rhythm of evolution fast, ${ }^{246}$ such as in electronic communications. In this sense and from the viewpoint of innovation as a one of the goals of economic regulation, the whole discussion on the essential facilities doctrine could be construed along the lines of the dilemma between service-based or facility-based competition..$^{247}$

239 ABbott B. LIPSKY, JR. and J. GREGORY SIDAK, supra note 199, at p. 1231. Lipsky and Sidak stated that, "[t]he central economic and legal difficulty with mandatory access regimes is that they rest upon involuntary exchange rather the voluntary exchange that is more familiar to a capitalist economy. In takings law, compensation for government confiscation of property is deemed to be constitutionally 'just' if it equals the price to which a willing buyer and a willing seller would agree. Just compensation mimics the outcome of voluntary exchange". See with regard to the just compensation in the US Microsoft case, ABBOTT B. LIPSKY, JR. and J. GREGORY SIDAK, ibid. at pp. 1231 et seq.

${ }^{240}$ For an overview of all pricing methodologies, see DAMIEN GERADIN and MiCHEL KERF, Controlling Market Power in Telecommunications, Oxford: Oxford University Press, 2003, at pp. 34-45.

${ }^{241}$ See Implementation of the Local Competition Provisions in the Telecommunications Act of 1996, CC Docket No 96-98, First Report and Order, 11 FCC Rcd 15499 (1996) (Local Competition Order), aff'd in part and vacated in part sub nom. Comp. Tel. Assoc. v. FCC, 117 F.3d 1068 (8 $8^{\text {th }}$ Cir. 1997) and Iowa Utils. Bd. v. FCC, 120 F.3d 753 (8th Cir. 1997), aff'd in part and remanded, ATET v. Iowa Utils. Bd., 525 US 366 (1999); on remand Iowa Utils. Bd. v. FCC, 219 F.3d 744 (8 ${ }^{\text {th }}$ Cir. 2000) (Iowa Utilities II), reversed in part sub nom. Verizon Communications Inc v. FCC, 535 US 467 (2002).

242 ABBOtT B. LIPSKY, JR. and J. GREGORY SIDAK, supra note 199, at p. 1232. See also MARCEL CANOY, PAUL DE BIJL and RON KEMP, "Access to Telecommunications Networks" in PIERRE A. BUIGUES and PATRICK REY (eds.), The Economics of Antitrust and Regulation in Telecommunications, Cheltenham, UK: Edward Elgar Publishing, 2004, pp. 135-168 and JUAN DELGADO, JÉRÔME FEHRENBACH and ROBERT KLOTZ, "The Price of Access: Unbundling the Local Loop in the EU", ibid. pp. 169-182.

243 See e.g. JEAN-JACQUES LAFFONT and JEAN TIROLE, Competition in Telecommunications: Munich Lectures in Economics, Cambridge, MA: MIT Press, 2000; OECD, Access Pricing in Telecommunications, Paris: OECD Publishing, 2004. See also Telecom Corporation of New Zealand Ltd v. Clear Communications Ltd [1995] 1 NZLR 385.

${ }^{244}$ ABBOTT B. LIPSKY, JR. and J. GREGORY SIDAK, supra note 199, at p. 1223 (emphasis in the original).

245 ROBERT PITOFSKY, DONNA PATTERSON and JONATHAN HOOKS, supra note 196, at pp. 451 et seq.

${ }^{246}$ For a proposal for new type of application of the EFD. See JAMES TURNEY, supra note 224, at pp. 198 et seq.

${ }^{247}$ Mats Bergman points out in this context that, "the effect of the doctrine is similar to the effect of a price regulation of that stage of production - i.e., prices will be reduced, which is likely to bring price reduction in the related market as well. There is a short-run positive effect on competition, from which consumers will benefit. However, the price reduction will decrease the profit of the monopolist, which, in turn, is likely to reduce the monopolist's incentives to invest. Therefore, long-run negative effects from reduced incentives to invest are likely". See MATS A. BERGMAN, "The Role of Essential Facilities Doctrine" (2001) Antitrust Bulletin, Vol. 46, pp. 403 et seq., at p. 422. 
The above line of reasoning was interestingly followed in the recent case of the US Supreme Court, Verizon Communications Inc. v. Law Offices of Curtis V. Trinko (hereinafter Trinko). ${ }^{248}$ The Supreme Court made therein, among others, three important conclusions that are pertinent to the present context: (i) firstly, it substantially narrowed down the possibilities for granting mandatory access and held that its ruling in Aspen Skiing, ${ }^{249}$ which is normally identified as the epitome of the essential facilities doctrine, was "at or near the outer boundary of Section 2 liability". ${ }^{250}$ Indeed, it dismissed the EFD itself as "crafted by some lower courts"; 251 (ii) secondly, the Court argued that mandatory access may conflict with one of the objectives of antitrust by reducing incentives to invest; ${ }^{252}$ and (iii) thirdly, it found that if antitrust courts were to grant access to essential products or services, this would force them to act as "central planners", since they would essentially need to engage in pricing and other regulatory discussions for which they are ill-suited. 253

\subsubsection{TYING}

\subsubsection{THE CONCEPT OF TYING IN EC LAW}

Normally, abuses within the meaning of Article 82 EC can only be committed in the market where the dominant position is established. However, under special conditions, a dominant undertaking may commit an abuse in neighbouring markets to that where it holds a dominant position. In Tetra Pak II, for instance, the $\mathrm{CFI}^{254}$ and the ECJ ${ }^{255}$ confirmed the Commission's finding 256 that Tetra Pak had committed abuses in the markets for non-aseptic packaging machines and non-aseptic cartons, while its dominant position had only been established in the market for aseptic machines and cartons. ${ }^{257}$ In that most prominent case of leverage of market power, the Court did however explicitly acknowledge that, "the application of Article 86 [now $82 \mathrm{EC}$ ] to conduct found on the associated, non-dominated markets and having effects on that associated market can only be justified by special circumstances“.258

\footnotetext{
${ }^{248}$ See supra 201. On the Trinko case, see e.g. DAMIEN GERADIN, supra note 196; PHILIP J. WEISER, “The Relationship of Antitrust and Regulation in a Deregulatory Era" (2005) Antitrust Bulletin, Vol. XX, pp. 1-29; NICHOLAS ECONOMIDES, "Vertical Leverage and the Sacrifice Principle: Why the Supreme Court Got Trinko Wrong", Stern School of Business Working Paper 05-05, August 2005; JonAthan L. RuBIN, "The Truth About Trinko" (2005) Antitrust Bulletin, Vol. XX, pp. 1-13; JAMES E. SCHEUERMANN and William D. SEMINS, "A New Method for Regulatory Antitrust Analysis? Verizon Communications Inc. v. Trinko" (2005) Richmond Journal of Law and Technology, Vol. XII, Issue I.

${ }^{249}$ See supra note 199.

250 See Trinko, supra 201, at p. 9.

251 Ibid. at p. 11.

252 Ibid. at pp. 11 et seq.

${ }^{253}$ Ibid. at p. 8. In the words of the Supreme Court: "Enforced sharing also requires antitrust courts to act as central planners, identifying the proper price, quantity, and other terms of dealing - a role for which they are ill-suited“. See DAMIEN GERADIN, supra note 196, at pp. 1524 et seq.

${ }^{254}$ Case T-83/91 Tetra Pak v. Commission (Tetra Pak II) [1994] ECR II-755, [1997] 4 CMLR 726.

255 Tetra Pak II, OJ 1992 L 72/1, [1992] 4 CMLR 551.

256 Case C-333/94 P Tetra Pak v. Commission (Tetra Pak II), supra note 44.

257 Where in fact it had a market share of nearly 90 per cent.

258 Case T-83/91 Tetra Pak v. Commission (Tetra Pak II), supra note 254, at para. 27 (emphasis added).
} 
Such special circumstances may often be found to exist in the communications industry where market players operate in multiple markets. The Access Notice ${ }^{259}$ stresses therefore that the concept of leveraging market power developed in Tetra Pak II could be important in the communications sector. It refers to the finding of the Court of Justice therein that in a situation of extremely close links between the dominated and non-dominated market, and given the extremely high market share on the dominated market, Tetra Pak was "in a situation comparable to that of holding a dominant position on the markets in question as a whole“ ${ }^{260}$ The Notice goes on and extends the proposition of Tetra Pak II, which concerned horizontal markets, to closely related vertical markets as well (which are, in fact, common situations in communications, since operators often have an extremely strong position on infrastructure markets and on markets downstream of that infrastructure). ${ }^{261}$

Leveraging of market power could take different forms. Article 82(2)(d) EC proscribes a particular type of leveraging, namely the "making the conclusion of contracts subject to acceptance by the other parties of supplementary obligations which, by their nature or according to commercial usage, have no connection with subject of such contracts" ${ }^{262}$

Such an abuse is often referred to as "tying" and it deprives, in effect, customers of a realistic choice to purchase the product being tied from other sources, or not to buy it all. ${ }^{263}$ The main negative effect of tying on competition is the possible foreclosure on the market of the tied product. ${ }^{264}$ It may further lead to creation of artificial economies of scale; raising rival's costs; decreasing rival's benefits; leveraging of market power; protection of market power on the first (tied) market; ${ }^{265}$ hidden pricing or a mixture of these. ${ }^{266}$

Tying could be of particular importance in electronic communications as a competitive strategy. ${ }^{267}$ At least three factors determine the importance of tying in the communications industry: (i) firstly, communications services and/or products are extremely diverse and could

259 See also SMP Guidelines, at paras 83-85.

260 Access Notice, at para. 65, referring to Tetra Pak II, supra note 44 .

261 Access Notice, at paras 65-67.

262 Tying may also be abusive under Article 81 EC as part of horizontal agreements or concerted practices between competing suppliers who make the sale of one product conditional upon the purchase of another distinct product. Tying may also constitute a vertical restraint falling under Article $81 \mathrm{EC}$ where it results in a single branding type of obligation for the tied product. See EUROPEAN COMMISSION, Guidelines on vertical restraints, OJ C 291/1, 13 October 2000, at paras 215 et seq.

${ }^{263}$ In his report to the Department of Trade and Industry (DTI), Nalebuff makes a distinction between tying and bundling and defines these practices in much detail. See BARry NAlebufF, "Bundling, Tying, and Portfolio Effects", DTI Economics Paper No 1, Part I: Conceptual Issues, February 2003, at pp. 13 et seq.

${ }^{264}$ Dennis W. CARLton and Michael WALDMAN, "The Strategic Use of Tying to Preserve and Create Market Power in Evolving Industries", available at <http://gsbwww.uchicago.edu/research/ cses/WorkingPapersPDF's/145.pdf $>$, also published in (2002) RAND Journal of Economics, Vol. 3, No 2, pp. 194-220, at pp. 22 et seq.

265 DENNIS W. CARLTON and Michael WALDMAN, ibid. at pp. 6 et seq.

${ }^{266}$ For a full account, see BARRY NALEBUFF, supra note 263, at pp. 39 et seq. See also Guidelines on vertical restraints, supra note 262, at para. 217; MiChAEL D. Whinston, "Tying, Foreclosure, and Exclusion" (1990) American Economic Review, Vol. 80, No 4, pp. 837-859 and DENNIS W. CARLTON and MiCHAEL WALDMAN, supra note 264.

267 The Access Notice stresses the importance of tying, saying that, "[ $t$ ]his is of particular concern where it involves the tying of services for which the TO is dominant with those for which it is not. Where the vertically integrated dominant network operator obliges the party requesting access to purchase one or more services without adequate justification, this may exclude rivals of the dominant access provider from offering those elements of the package independently. This requirement could thus constitute an abuse under Article 86 [now 82 EC]". 
be relatively easily provided in packages; (ii) secondly, because communications are to a great extent driven by customers' expectations (which are not necessarily predictable in advance), there is a pronounced willingness from the producers' side to offer as many variations as possible in order to meet these expectations and appeal to the broadest of public; and (iii) thirdly, because of the inherent network effects and the possibility of tipping markets, tying could be an adequate tool for a company already dominant in one market to attempt conquering another. ${ }^{268}$

Tying could take multiple actual expressions and may be of products with their accessories needed for their functioning, ${ }^{269}$ between products in the same range ${ }^{270}$ or tying of a product and related services. ${ }^{271}$ Pricing practices having a tying effect have also been condemned as abusive: Loyalty rebates, ${ }^{272}$ across the board rebates, ${ }^{273}$ target discounts, ${ }^{274}$ uniform delivered pricing 275 and "top slice" rebates ${ }^{276}$ have all been found in breach of Article 82 EC.

Pursuant to the law and practice of the European Commission and the Community Courts, an analysis of a tying case involves a five-pronged test. ${ }^{277}$ The following paragraphs will shed some light upon these five constituent elements of the tying test. We shall use examples from the Commission's decision in Microsoft, ${ }^{278}$ a case that is also an illustration of antitrust application to new economy sectors.

(i) The first indispensable element is dominance of the seller in the market for the tying product. Only a company holding a dominant position in a given market can successfully impose tying on its customers since the latter are dependent on this company for the supply of at least one of these products. ${ }^{279} \mathrm{~A}$ dominance of the seller was found, for instance, in Hilti. ${ }^{280}$ In this classic

${ }^{268}$ DENNIS W. CARLTON and Michael WALDMAN, supra note 264, at p. 35. See also MAURITS DOLMANS and THOMAS GRAF, "Analysis of Tying under Article 82 EC: The European Commission's Microsoft Decision in Perspective" (2004) World Competition, Vol. 27, No 2, pp. 225-244, at pp. 234 et seq.

${ }^{269}$ Eurofix-Bauco v. Hilti, supra note 141; upheld in Case T-30/89 Hilti AG v. Commission, supra note 113 and Case C-53/92 P Hilti AG v. Commission, supra note 73. See also Tetra Pak II, supra note 255.

${ }^{270}$ Hoffmann-La Roche, supra note 35.

${ }^{271}$ Napier Brown-British Sugar, supra note 72.

272 See e.g. Hoffmann-La Roche, supra note 35.

273 Ibid.

${ }^{274}$ Case 322/81 Michelin v. Commission, supra note 44.

275 Napier Brown-British Sugar, supra note 72.

276 Soda-Ash - Solvay OJ 1991 L 152/51 and Soda-Ash - ICI OJ 1991 L 152/40, [1994] 4 CMLR 645 (both annulled on procedural grounds by the CFI in Case T-30/91 Solvay SA v. Commission [1995] ECR II-1775, [1996] 5 CMLR 57).

277 MAURITS DOLMANS and THOMAS GRAF, supra note 268, at p. 226. See also JONATHAN FAULL and ALI NIKPAY, supra note 19, at paras 3.197 et seq. and Case COMP/C-3/37.792 Microsoft, supra note 74, at para. 794.

${ }^{278}$ Case COMP/C-3/37.792 Microsoft, ibid. in particular at paras 792-989. On the Microsoft Decision, see further MAURITS DOLMANS and THOMAS GRAF, supra note 268; DAVID S. EVANS and ATILANO JORGE PADILlA, "Tying under Article 82 EC and the Microsoft Decision" (2004) World Competition, Vol. 27, No 4, pp. 503-512; OlIVER SITAR, "The EU Microsoft Decision" (2004) Medien und Recht (international edition), Vol. 1, pp. 2-5; ROBERTO PARDOLESI and ANDREA RENDA, "The European Commission's Case against Microsoft: Kill Bill?" (2004) World Competition, Vol. 27, No 4, pp. 513-566; FRANÇOIS LÉVÊQUE, "Innovation, Leveraging and Essential Facilities: Interoperability Licensing in the EU Microsoft Case (2005) World Competition, Vo. 28, No 1, pp. 1-91; VAlEnTINE KORAH, Intellectual Property Rights and the EC Competition Rules, Oxford/Portland, Oregon, 2006, at pp. 150-167.

279 The Commission pointed in Hilti that, "the ability to carry out its illegal policies stems from its power on the market for Hilti-compatible cartridge strips and nail guns (where its market position is strongest and the barriers to entry are highest) and aims at reinforcing its dominance on the Hilti-compatible nail market (where it is potentially more vulnerable to competition)". See Eurofix-Bauco v. Hilti, supra note 141, at para. 74 . 
example of tying, Hilti, the well-known producer of nail guns attempted to use his market power on the markets for Hilti-compatible cartridge strips and nail guns to eliminate independent producers of Hilti-compatible nails (where it was potentially most vulnerable to new competition). ${ }^{281}$ In a more recent case, Microsoft was found guilty of making the availability of the Windows Operating System conditional on the simultaneous acquisition of the Windows Media Player (WMP). ${ }^{282}$ As the dominant tying product, the Commission clearly identified PC (personal computers) operating systems, where, as ascertained, Microsoft had the mammoth market share of around 95 per cent kept through a long period of time. ${ }^{283}$

(ii) The second element is the existence of a tied product that is separate from the tying one. In order to establish tying as an abuse within the scope of Article 82 EC, it must be thus demonstrated that the products or services being tied together are independent from one another - there must be a distinct demand for both of them. ${ }^{284}$ Such a conclusion could normally be reached by analysing the nature of the products or services in question and their commercial usage. ${ }^{285}$ The presence of suppliers offering the tied product is a strong indicator that a distinct demand for it exists. ${ }^{286}$

This delineation exercise is however not always easy in practice, especially with relation to new products. "Indeed, deciding whether a new product is by nature a single unit, or whether each of its components should be considered an independent product, may become a rhetorical question. Indeed, if the product is new, there is no commercial usage to look at. In these cases, the weight of the analysis shifts from the question of whether the products sold together are independent, to the question of whether it is objectively justified to sell them together". 287

In the Microsoft decision, the software applications allowing users to play streamed and downloaded digital audio and video content, known as media players, were identified as the separate tied product, distinct from the PC operating systems. ${ }^{288}$

(iii) The third constituent element is coercion, i.e. conduct forcing customers to buy the tied product together with the tying. This is a defining element of the abuse. In the absence of it, even a dominant company is allowed to sell two products or services together. However, when the consumers are forced, coerced, to buy them together, then the tying falls under the

${ }^{280}$ Eurofix-Bauco v. Hilti, ibid. upheld in Case T-30/89 Hilti AG v. Commission, supra note 113 and Case C-53/92 P Hilti AG v. Commission, supra note 73.

${ }^{281}$ Eurofix-Bauco v. Hilti, ibid. at para. 74.

${ }^{282}$ Case COMP/C-3/37.792 Microsoft, supra note 74.

$283 \mathrm{Ibid}$. at paras 431 et seq.

${ }^{284}$ Case T-86/95 Compagnie Generale Maritime [2002] ECR II-1011, at para. 159.

285 See Case T-83/91 Tetra Pak v. Commission (Tetra Pak II), supra note 254.

${ }^{286}$ MAURITS DOLMANS and THOMAS GRAF, supra note 268, at p. 227. The Commission's Guidelines on vertical restraints (supra note 262) state at para. 216 that two products are distinct if, in the absence of tying, from the buyers' perspective, the products are purchased by them on two different markets.

287 JONATHAN FAULL and ALI NIKPAY, supra note 19, at para. 3.200.

${ }^{288}$ Case COMP/C-3/37.792 Microsoft, supra note 74, at paras 800-825. The Commission distinguished between downloading and streaming audiovisual content and concluded that software programmes that allow for streaming media constitute a separate relevant market. 
prohibition of Article 82 EC. The degree of coercion could vary in reality. It could be contractual, ${ }^{289}$ factual, ${ }^{290}$ through withdrawal of benefits, through pricing incentives ${ }^{291}$ or through combination of those. In the case of Microsoft, for instance, it was ascertained that the company gave the customers no choice to obtain Windows Operating Systems without the Windows Media Player, coercing the customers both contractually and technically to acquire both products together. ${ }^{292}$

One should however bear in mind that the perceptions as to what constitutes separate products, and what not, can evolve through time and products that were previously viewed as distinct ones, could be later taken as one. Air conditioner for cars is a typical case exemplifying this development. While, once automobiles and air condition systems had been perceived as two separate products, now they are taken as a whole..$^{293}$

(iv) A restrictive effect on competition for the tied product is the next constituent element of tying under Article 82 EC. Tying should affect or be able to affect competition in the tied market. ${ }^{294}$ It is however not always clear how much effect on competition is needed in order to justify an intervention. ${ }^{295}$ The specific characteristics of the market under scrutiny will certainly have to be accounted for. Markets characterised by network externalities may be in that sense more vulnerable to tying and/or tying could have more appreciable effects. This is due to the fact that in such markets the number of consumers, who acquire the product influences the future demand of the product. The greater the thereby created network, the more attractive it becomes to join. 296 "In such cases, a tie will have an impact beyond the tied customer share because the increased distribution share resulting from the tie will also impact on future demand for the tied product“. ${ }^{297}$

The effect on markets driven by innovation or emerging ones should also be accordingly considered. This was the argumentation used by the Commission in the Microsoft decision, where it held that the tying at issue "...shields Microsoft from effective competition from potentially more efficient media player vendors which could challenge its position. Microsoft thus reduces the talent and capital invested in innovation of media players, not least its own and anti-competitively raises barriers to market entry. Microsoft's conduct affects a market

${ }^{289}$ Case T-83/91 Tetra Pak v. Commission (Tetra Pak II), supra note 254.

290 Case T-30/89 Hilti AG v. Commission, supra note 113.

291 Ibid.

${ }^{292}$ Case COMP/C-3/37.792 Microsoft, supra note 74, at paras 826-834.

293 MAURITS DOLMANS and THOMAS GRAF, supra note 268, at p. 227; RICHARD WHISH, supra note 15, at p. 661.

294 "... [F] or the purposes of establishing an infringement of Article 82 EC, it is not necessary to demonstrate that the abuse in question had a concrete effect on the markets concerned. It is sufficient in that respect to demonstrate that the abusive conduct of the undertaking in a dominant position tends to restrict competition, or, in other words, that the conduct is capable of having, or likely to have, such an effect". See T-219/99 British Airways plc v. Commission, ECR [2003] II-05917, at para. 293.

295 See MAURITS DOLMANS and THOMAS GRAF, supra note 268, at pp. 233 et seq.

296 In the Microsoft case, the Commission pointed out that, “...in view of the indirect network effects obtaining in the media player market, the ubiquitous presence of the WMP code provides it with a significant competitive advantage, which is liable to have harmful effect on the structure of competition in that market". See Case COMP/C-3/37.792 Microsoft, supra note 74, at para. 878.

${ }^{297}$ MAURITS DOLMANS and THOMAS GRAF, supra note 268, at p. 234. 
which could be a hotbed for new and exciting products springing forth in a climate of undistorted competition“. 298

(v) The final element of tying, negatively formulated, is the absence of an objective and proportionate justification for the coercion. The Court has held that, "...even where tied sales of two products are in accordance with commercial usage, or there is a natural tie between the two products in question, such sales may still constitute abuse within the meaning of Article 86 [now $82 \mathrm{EC}$ ] unless they are objectively justified“. ${ }^{299}$ Enhancement of efficiency (productive or distributive) or guaranteeing of quality and safety are often given as reasons for the tying, and sometimes are genuine ones. The dominant undertaking will have the burden to prove whether the tying is indeed objectively justified and proportionate. ${ }^{300}$

\subsubsection{OBSERVATIONS ON TYING AS AN ABUSE}

It seems that the above five-element test provides a clear (albeit complex) basis for addressing leverage of market power through tying products and/or services. Upon closer examination, this might not however be the case. Although the constituent elements of a tie may be duly fulfilled, the treatment of tying practices as an abuse of dominant position and the resultant antitrust intervention is not clear-cut and subject to frequent criticism. ${ }^{301}$

Tying may indeed be essential for reasonable purposes, such as maintaining the efficiency of the tying product, which does not function as well with other additives or materials, or to enable economies of scale. ${ }^{302}$ It could also be a legitimate strategy of offering a variety of products and/or services for the sake of competing on the merits. ${ }^{303}$ Most notably in our context, it seems that in dynamic industries characterised by network effects, tying could not simply be taken as an abuse per se but will have to be examined following a rule of reason.

Such was the conclusion drawn at least at the other side of the Atlantic in a case very similar to our working example of European Commission v. Microsoft. Similar, firstly, because it involved the same company, i.e. the Redmond-based software giant Microsoft and secondly, because the allegations of refusal to supply and tying were discussed, although under

${ }^{298}$ Case COMP/C-3/37.792 Microsoft, supra note 74, at para. 981 (footnote omitted; emphasis added).

${ }^{299}$ Case C-333/94 P Tetra Pak v. Commission (Tetra Pak II), supra note 44, at para. 37.

300 See e.g. Opinion of AG Cosmas in Case C-344/98 Masterfoods [2000] ECR I-11369, at para. 101. See also MAURITS DOLMANS and THOMAS GRAF, supra note 268, at pp. 235 et seq. on the elements of the proportionality test. For the Commission's argumentation in Microsoft, see Case COMP/C-3/37.792 Microsoft, supra note 74, at paras 956-970.

301 See e.g. ROBERT H. BORK, supra note 26, at pp. 365-381 and FrEDERIC M. SCHERER and DAVID ROSS, Industrial Market Structure and Economic Performance, 3rd edition, Boston, MA: Houghton Mifflin, 1990, at pp. 565 et seq. The Chicago School has been especially critical of the sanctioning of tying as an antitrust abuse. For a brief overview of the Chicagoan arguments in this context and a critique, see MAURITS DOLMANS and THOMAS GRAF, ibid. at pp. 232 et seq.; BARRY NALEBUFF, supra note 263, at pp. 18 et seq. See also DAVID S. EVANS and ATILANO JORGE PADILlA, supra note 278; ROBERTO PARDOLESI and ANDREA RENDA, ibid.; Christian Ahlborn, Vincenzo Denicolò, Damien Geradin and Atilano Jorge Padilla, “DG Comp's Discussion Paper on Article 82: Implications of the Proposed Framework and Antitrust Rules for Dynamically Competitive Industries", 31 March 2006, available at <http://ssrn.com/abstract=894466>, at pp. 39 et seq.

302 Economic Advisory Group for Competition Policy (EAGCP), "An Economic Approach to Article 82", EAGCP Report for DG COMP, July 2005, available at <http:/europa.eu.int/comm/competition/ publications/publications/>, at p. 40. See also EUROPEAN COMMISSION, DG Competition Discussion Paper on the Application of Article 82 of the Treaty to Exclusionary Abuses, supra note 116 , at para. 178.

${ }^{303}$ For a full account of the efficiency reasons for tying, see BARRY NALEBUFF, supra note 263, at pp. 28 et seq. 
different circumstances. The US version of the Microsoft case ${ }^{304}$ in its "tying-part" concerned the bundling of Windows Operating System with the Microsoft's internet browser (Internet Explorer) and relate to what is colloquially known as the "browser war". ${ }^{305}$ The District Court of Columbia concluded that Microsoft's tie amounted to a per se violation of Section 1 of the Sherman Act. ${ }^{306}$ Upon appeal, however, the Appellate Court remanded the case for consideration under the rule of reason standard. ${ }^{307}$ After the remand, the US antitrust authorities decided not "to pursue further proceedings on the tying count of the original complaint $[. .$.$] in an effort to obtain prompt, effective and certain relief for consumers", 308$ so the question was regrettably left without an ultimate answer.

The change of methodology, i.e. the transition from a per se prohibition to a rule of reason approach is of the essence to our discussion here. ${ }^{309}$ If projected to the European Microsoft case and to similar new economy cases that might arise in the future, including electronic communications ones, it raises the interesting question of whether EC competition law is indeed prepared to handle them.

The analysis of the Commission's decision in Microsoft lends more credence to a negative answer of the latter question. Although the Commission acknowledged that the Microsoft case is not a classical tying one, ${ }^{310}$ it applied the classical analysis of tying in order to prove that Microsoft's practice created serious risks of foreclosing competition. We shall not go as far as to submit that the Commission did it all wrong, as some authors bluntly suggest, ${ }^{311}$ but nonetheless make a few critical notes.

${ }^{304}$ US v. Microsoft Corp, 87 F. Supp.2d 30 (D.D.C. 2000). On the US Microsoft case, see ABBOTT B. LIPSKY, JR. and J. GREGORY SIDAK, supra note 199, at pp. 1223 et seq.; FRANKLIN FISHER and DANIEL RUBINFELD, "US v. Microsoft - An Economic Analysis" (2001) The Antitrust Bulletin, Vol. 46, pp. 1-69; J. GREGORY SIDAK, "An Antitrust Rule for Software Integration" (2001) Yale Journal on Regulation, Vol. 18, No 1, pp. 1-81; MAURITS DOLMANS and THOMAS GRAF, supra note 268, at pp. 237 et seq. and the collection of essays in DAVID S. Evans (ed.), Microsoft, Antitrust and the New Economy, Boston/Dodrecht/London: Kluwer Academic Publishers, 2002.

305 The "browser war" concerned the intensive struggle for popularity among users and thus for market share in the late 1990s between Internet Explorer and Netscape Navigator, which had been the initial de facto standard. Internet Explorer came as the undisputed winner of this war. Currently, some see a "Second Browser War" between the Internet Explorer and the open source Mozilla's Firefox.

306 Section 1 prohibits "[e]very contract, combination in the form of trust or otherwise, or conspiracy, in restraint of trade or commerce...". See Sherman Antitrust Act, 15 USC., § 1.

307 US v. Microsoft Corp, 253 F.3d 34 (D.C. Cir. 2001), at 94.

308 US Department of Justice, "Justice Department Informs Microsoft of Plans for Further Proceedings in the District Court", Press Release, 6 September 2001, at p. 1.

309 The change of methodology and the transition to a rule of reason approach was not a surprising sudden decision in the case of Microsoft. It is indeed the result of a long debate in the US antitrust and in the economic and legal literature. See ROBERTO PARDOLESI and ANDREA RENDA, supra note 278, at pp. 561 et seq.

${ }^{310}$ Case COMP/C-3/37.792 Microsoft, supra note 74, at para. 841. The Commission clarified (ibid.) that, "[w]hile in classical tying cases, the Commission and the Courts considered the foreclosure effect for competing vendors to be demonstrated by the bundling of a separate product with the dominant product, in the case at issue, users can and do to a certain extent obtain third party media players through the Internet, sometimes for free".

${ }^{311}$ Pardolesi and Renda, for instance, conclude at the end of their paper that, "[t]he European Commission's allegation that Microsoft harmed competition and stifled innovation by monopolising the streaming media market through technological tying is not supported by sound economic theory. The Commission did not have the chance to deal with technological integration in previous cases, and showed all its impasse in dealing with the peculiar dynamics of system competition under (indirect) network effects“. See ROBERTO PARDOLESI and ANDREA RENDA, supra note 278, at p. 564. See also DAVID S. EVANS, ATILANO JORGE PADILLA and Michele POLO, "Tying in Platform Software: Reasons for a Rule-of-Reasons Standard in Europe" (2002) World Competition, Vol. 25, No 4, pp. 509-514. 
Firstly, the Commission found, among others, that due to the ubiquitous position of Microsoft in the market for operating systems and the inherent network effects, Microsoft was already tipping the market of media players towards a WMP standard, thereby foreclosing competition and stifling innovation. ${ }^{312}$ Although the acknowledgment of network effects and their consideration in the analysis of the Commission is highly commendable, their interpretation and ramifications are quite misjudged.

The foreclosure of competition by commingling the code of Windows and WMP ascertained by the Commission is indeed hard to see. ${ }^{313}$ Furthermore, the tipping of the market seems hardly probable. Some markets could tip because of network effects. However, this tipping should not be overstated since it does not occur always and automatically. Indeed, it occurs only under a specific set of factors and requires that consumers and producers of complementary products have strong incentives to standardise on one technology, or to put it more technically, "whenever a particular market is characterised by both strong network and learning effects". ${ }^{314}$ This is however not the case with media players. ${ }^{315}$ Even beyond complex econometrics, it seems in reality that the media players market is rather diverse. The success of Apple's iPod and online music stores (based on other than WMP formats) questions the suggested ubiquity of Microsoft's WMP. In its analysis, it is further noteworthy that the Commission ignored downloading of streaming media software as a competitive source to the Windows distribution channel, ${ }^{316}$ as well as other alternative distributive channels (such as bundling media players with other software or Internet access services). ${ }^{317}$

Secondly, even if we agree that the five-step test (as outlined above) has been properly applied by the Commission for the finding of anticompetitive tying, it should be stressed that the nature of technological integration is rather different from standard tying. ${ }^{318}$ Technological integration could be found to ultimately enhance consumer welfare by creating products that are better, faster or more versatile. ${ }^{319}$ In that sense, such an integration calls for a cautious rule of reason approach in order to establish whether the integrated product is more valuable to end users than the sum of its parts. ${ }^{320}$ Otherwise, any integration could simply be attacked by

312 Case COMP/C-3/37.792 Microsoft, supra note 74, at paras 835 et seq.

313 ROBERTO PARDOLESI and ANDREA RENDA, supra note 278, at pp. 559 et seq.

314 ROBERTO PARDOLESI and ANDREA RENDA, supra note 278, at p. 528. For an extensive analysis of the implications of network effects, see ibid. at pp. 526 et seq. See also ROBERTO PARDOLESI and ANDrEA RENDA, "How Safe is the King's Throne? Network Externalities on Trial“ in ANTONIO CUCINOTTA, ROBERTO PARDOlesi and Roger VAN DEN BERGH (eds.), Post-Chicago Developments in Antitrust Law, Cheltenham, UK: Edward Elgar, 2003, pp. 213-250.

315 DAVID S. EVANS and ATILANO Jorge PADILLA, supra note 278, at pp. 506 et seq.

316 Case COMP/C-3/37.792 Microsoft, supra note 74, at paras 858 et seq.

317 Ibid. at paras 872 et seq. See also the arguments of Microsoft in Order of the President of the Court of First Instance of 22 December 2004 in Case T-201/04 R Microsoft Corporation v. Commission of the European Communities, at paras 326 et seq.

318 ROBERTO PARDOLESI and ANDREA RENDA, supra note 278, at p. 561, referring also to DAVID S. EVANS, ATILANO JORGE PAdilla and Michele POlO, supra note 311; MAURITS DOlMANS and THOMAS GRAF, supra note 268; J. GREGORY SidAK, supra note 304

319 ROBERTO PARDOLESI and ANDREA RENDA, ibid.

${ }^{320}$ Ibid. 
competitors of the product or service in question for the sake of their own protection instead of the protection of the consumers. ${ }^{321}$

Thirdly, as a final argument, even if technological integration equals standard tying and "[e]ven if the market ends up tipping toward a single de facto standard technology, end users will profit from standardisation and from intra-system competition, which allegedly will prevent Microsoft from charging supracompetitive prices and fall into irreversible $x$ inefficiency". ${ }^{322}$ It is out of the scope of this work (and the expertise of the author) to figure out what the possible efficiencies from commingling the Windows Media Player with the operating system could be, it is however most noteworthy that the Commission did not properly address such issues of potential efficiency and did not balance them against the alleged foreclosure effects. Although it dwelt (rather briefly) upon some efficiencies, ${ }^{323}$ the question of consumer harm in assessing the competitive impact of Microsoft was never directly addressed. ${ }^{324}$ In this way, the consumer welfare analysis of the Commission was left incomplete and the rule of reason approach was thus not fully applied in the manner formulated in the US Microsoft case ${ }^{325}$ (although the Commission contends the opposite). ${ }^{326}$

Finally, two comments as to the effects of the Commission's decision could be added. In the broader context of competition policy, one can contemplate on whether tying provides the adequate framework for addressing leveraging of market power in network industries at all. ${ }^{327}$ Since, "[i]t is apparent from the Commission's theory that tying is not the 'disease' since untying is not the 'cure'. The problem in the Commission's view is that Microsoft has an advantage in distributing its technology that others cannot match. It would not appear that the standard remedy for tying solves this alleged problem since virtually all computer manufacturers (and consumers) will likely continue to take the version of Windows with

321 There has been, for instance, a complaint brought before the European Commission focusing on the Microsoft bundle of applications. See PAUl Meller, "In Europe, Microsoft Faces a New Antitrust Complaint", The New York Times, 23 February 2006.

322 ROBERTO PARDOLESI and ANDREA RENDA, supra note 278, at p. 564 (emphasis added).

323 Case COMP/C-3/37.792 Microsoft, supra note 74, at paras 956-970.

324 ROBERTO PARDOLESI and ANDREA RENDA, supra note 278, at p. 562.

325 See US v. Microsoft Corp, supra note 307, in particular at 95-97.

${ }^{326}$ Although Mario Monti stated with that regard: "I would like to stress that the Commission has not ruled that tying is illegal per se, but rather developed a detailed analysis of the actual impact of Microsoft's behaviour, and of the efficiencies that Microsoft alleges. In other words we did what the US Court of Appeals suggested be done: we used the rule of reason although we don't call it like that in Europe". See "Microsoft: Statement by EU Commissioner Mario Monti", News Release No 47/04, 24 March 2004.

${ }^{327}$ For an interesting opinion on the relation between tying and the essential facilities doctrine as antitrust tools directed at leveraging of market power, see THOMAS A. PIRAINO, JR., "An Antitrust Remedy for Monopoly Leveraging by Electronic Networks" (1998) Northwestern University Law Review, Vol.93, No 1, pp.50-63. Piraino argues that antitrust litigants and regulators should apply the EFD rather than tying claims to problems of monopoly leveraging in network industries. For a critical comment, see JAMES B. SPETA, "Tying, Essential Facilities, and Network Industries" (1999) Northwestern University Law Review, Vol. 93, No 4, pp. 1277-1286. 
media player technologies". ${ }^{328}$ It is indeed uncertain whether there will be any benefits from the Microsoft decision, especially in the medium to long term. ${ }^{329}$

From a comparative legal perspective, it appears that the European Microsoft case departs from its US counterpart in terms of methodology and rigour of the antitrust intervention. Some authors rather radically conclude that if the EC decision were to be upheld, 330 "the divergence with American antitrust law will be clear and incontrovertible". ${ }^{331}$ Even not necessarily Microsoft-friendly voices, such as Lawrence Lessig, viewed the Microsoft decision as "imperfect justice" and expressed certain worries that, "if every Microsoft innovation launches an antitrust investigation, then innovation will move to companies that don't pay such a high price". 332

To conclude, beyond the scope of the Microsoft (the final outcome of which is still unclear ${ }^{333}$ ), tying may indeed lead to a decrease of consumer welfare and its foreclosure effects could be especially critical in newly emerging markets. ${ }^{334}$ But it could also have positive effects. In dynamic environments, such as communications, the Courts will have to not only apply the established precedents but genuinely assess the efficiencies of the tie and weigh the trade-offs through a cost-benefit analysis. ${ }^{335}$ Because, although it seems fairly easy to brand tying as an entirely negative (and "dangerous") phenomenon, its long-term benefits are not unequivocal. ${ }^{336}$ We should bear in mind that Article 82 EC exists for the protection of competition and not competitors. The whole discussion of how to promote consumer welfare could also be seen within the broader framework of the goals of regulation, which is in itself a complex system.

\subsection{CONCLUSIONS ON EC COMPETITION RULES}

The above Sections provided a brief overview of some of the main concepts and principles of the European Community competition law, concentrating on Article 82 EC as the prime instrument for control of unilateral behaviour of undertakings and thus market power. The

${ }^{328}$ DAVID S. EVANS and ATILANO JORGE PADILLA, supra note 278, at p. 505. The Commission imposed a fine of $€ 497196304$ and a number of remedies on Microsoft, among others, notably, to provide its competitors with interoperability information and to unbundle Windows Media Player from Windows operating systems. Microsoft was allowed however to offer the version without WMP at a same price as the version with WMP. On the imposed remedies and fines, see paras 994 et seq.

${ }^{329}$ ROBERTO PARDOLESI and ANDREA RENDA, supra note 278, at pp. 564-565.

330 The case is currently before the Court of First Instance (Case T-201/04 R) after the action brought by Microsoft in July 2004 (see supra note 74). The first hearings were held before the Court between 24 and 28 April 2006. The outcome of the case is however unlikely to be decided soon. See e.g. Neue Zürcher Zeitung, "Showdown im Streit zwischen Microsoft und der EU", 22 April 2006.

331 JONATHAN ZUCK and LAURENT RUESSMANN, "The Transatlantic Riff in Antitrust Law", International Herald Tribune, 16 August 2004. See also in the same vein, ROBERTO PARDOLESI and ANDREA RENDA, ibid. at pp. 565-566.

332 LAWRENCE LESSIG, “Antitrust Smackdown“, Wired Magazine, Issue 12.06, June 2004.

333 See supra note 74.

${ }^{334}$ DENNIS W. CARLTON and Michael WALDMAN, supra note 264, at p. 2.

335 This could be a particularly difficult task in dynamic industries exhibiting network effects. For instance, there could be situations where "[i]n the presence of network externalities, a virtual ties can sometimes be effectively created by setting the price of the complementary product good sufficiently low". DENNIS W. CARLTON and MICHAEL WALDMAN, ibid. at p. 33.

336 DenNis W. CARLtON and Michael WALDMAN, ibid. at pp. 34 et seq. 
result, although essentially incomplete, proves the versatility of competition rules and the complexity of their application. The outcome confirmed our prior findings, where we analysed competition law and sectoral regulation on a more abstract, typological level. In the concrete context of European Community's law, we can now conclude that as one of the two regulatory tools applied to electronic communications (and possibly the only one in the future), EC competition rules could be described as a fine and efficient tool bringing markets into their natural state of competition and flexibly approaching diverse circumstances and new situations.

On the other hand, what has also become evident from the above Sections is that the line between what is deemed anti-competitive and what competition-conform could be a very subtle one. Although the law and practice of the EC institutions have been increasingly aligned with economic theory, some concepts (among others, essential facilities and tying, as elaborated upon) are still lacking a firm basis and a clear pattern of interpretation and implementation. Indeed, what one can observe on the basis of the two concrete examples that we provided, is an inconsistency of the regulatory potential of antitrust to approach communications typical situations. Whereas, in the case of the EFD, the test of essentiality is set at a level that is almost insurmountable and thus allows no access for new market players, in the case of tying, applying Article 82 EC may punish behaviour intrinsic to dynamic industries without a proper justification.

Further, we noted that the specificities of the communications environment complicate the antitrust application at all levels and challenge some conventional patterns of analysis. It could be then even suggested that the degree of these challenges is so high that competition rules cannot cope with them any longer. Such was, in fact, the argument made by Microsoft's defence in the discussed case. ${ }^{337}$ The software company contended therein that the traditional analytical approach to market definition and market power that has been used by antitrust authorities is not well suited to the so-called new economy industries. It stated that, "an industry under the sway of Moore's law cannot be analysed properly by the methods conventionally applied to market analysis in competition law cases". ${ }^{338}$

Indeed, as shown above, there are certain new elements that have to be considered expressly. Nonetheless, to use the words of the European Commission, responding to Microsoft's claim, “[t]his $[\ldots]$ does not mean that no antitrust analysis could be applied to 'new economy' markets. In fact, the specific characteristics of the market in question (for example, network effects and the applications barrier to entry) would rather suggest that there is an increased likelihood of positions of entrenched market power, compared to certain 'traditional industries'", 339

337 Case COMP/C-3/37.792 Microsoft, supra note 74, in particular at paras 465 et seq.

338 Microsoft's submission of 17 November 2000, CHRISTIAN VON WEIZSÄCKER, Comments on the Commission's Statement of Objections Filed against Microsoft, at paras 12-34, as referred to by Case COMP/C-3/37.792 Microsoft, supra note 74, at para. 465 (footnote omitted). See also Microsoft, ibid. at paras 466 et seq.

${ }^{339}$ Case COMP/C-3/37.792 Microsoft, ibid. at para. 470, referring also to MiCHAEL KATZ and CARL SHAPIRO, "Antitrust in Software Markets", paper prepared for the Progress and Freedom Foundation conference, Competition, Convergence and the Microsoft Monopoly, 5 February 1998, available at <http://faculty.haas.berkeley.edu/shapiro/software.pdf>. 
The question then is whether competition law can properly tackle such positions of "entrenched market power". Accounting for the specifics of electronic communications markets, it is clear that a mere examination of market shares will not suffice. A thorough and overall analysis of the economic characteristics of the relevant market would be needed before coming to a conclusion as to the existence of dominance. In a broader policy context, any decision for antitrust intervention will essentially involve "a trade-off between short-term and long-term competition, and so should be handled very carefully" 340 and in view of the regulatory objectives.

\section{EUROPEAN COMMUNITY COMMUNICATIONS SPECIFIC LEGISLATION}

Having outlined the first pillar of the communications law of the European Community in the face of the all-capturing, ever-applicable competition rules, the following Sections will focus on the second instrument of the communications regulatory toolkit. These are the sectoral rules that have been designed specifically for the telecommunications environment. As already stressed, the European Community regulatory rules for the telecommunications industry have undergone multiple modifications in order to transform the sector from monopoly to competition. This transformation process, which bring us to the current state of the market, was neither easy nor fast. It took more than 15 years and required the political will of the Member States and the pro-active policy of the European Commission.

Although now we seem to take this development for granted, as Pierre Larouche notes, "[w]ithout any doubt, the complete liberalization of the telecommunications sector on 1 January 1998 will rank as one of the main achievements of the European Union in the 1990s". ${ }^{341}$ Considering the significance of the liberalisation process and in order to see the differences between the liberalisation regulatory model(s) and the current post-liberalisation regime, it is worth taking a brief look back and find out how exactly European telecommunications changed.

\subsection{THE LiBERALISATION OF THE EUROPEAN COMMUNITY COMMUNICATIONS MARKETS}

The liberalisation of the EC telecommunications sector has been achieved through a gradual erosion of the existing special and exclusive rights granted to the historic monopolists (i) in relation to the operation of infrastructure to allow competition with these and (ii) in relation the services that the alternative and new operators were permitted to provide over these networks. This process that has unfolded in the past two decades commenced with the adoption of the Green Paper on the development of the common market for

\footnotetext{
340 JONATHAN FAULL and ALI NIKPAY, supra note 19, at para. 3.143. The authors made the remark in the particular context of the application of Article 82 EC to refusal to supply.

341 PIERRE LAROUCHE, supra note 8 , at p. xxxv.
} 
telecommunications services and equipment ${ }^{342}$ in 1987. The latter set out a comprehensive policy framework for action in the telecommunications sector. Its wide-ranging programme aimed at several strategic targets:

(i) progressive opening of the telecommunications terminal equipment and telecommunication services markets to competition;

(ii) full mutual recognition of type-approval for terminal equipment;

(iii) clear separation of regulatory and operational telecommunications activities in the Member States to conform to the EC Treaty competition rules;

(iv) establishment of open access conditions to networks and services through the Open Network Provision (ONP) programme; and

(v) establishment of the European Telecommunications Standards Institute (ETSI) ${ }^{343}$ in order to stimulate European standardisation.

\subsubsection{THE LiBERALISATION PACKAGE}

\subsubsection{The TELECOMMUNICATIONS TERMINAL EQUIPMENT DIRECTIVE AND THE TELECOMMUNICATIONS SERVICES DIRECTIVE}

Following the strategy of the Green Paper, the first two directives that provided the basis of the EC liberalisation programme and the model used for the Commission's further liberalisation measures were the Telecommunications Terminal Equipment Directive and the Telecommunications Services Directive:

(i) Commission Directive 88/301/EEC on competition in the markets for telecommunications terminal equipment ${ }^{344}$ provided for the abolition of the monopolies traditionally enjoyed by telecommunications administrations in the Member States for the supply, connection and maintenance of terminal equipment and for the publishing of the technical specifications and details of their type-approval procedures for terminal equipment. It required the separation of regulatory and operational functions of the relevant undertakings responsible for the drawing up of specifications for terminal equipment, monitoring their application and granting typeapproval.

342 EUROPEAN COMMISSION, Green Paper on the development of the common market for telecommunications services and equipment: Towards a dynamic European economy, COM(1987) 290 final, 30 June 1987. On the Green Paper, see THOMAS KIESSLING and YVES BLONDEEL, "The EU Regulatory Framework in Telecommunications" (1998) Telecommunications Policy, Vol. 22, No 7, pp. 571-592.

${ }^{343}$ The ETSI was founded in 1988. It brings together not only regulators but also network operators, service providers and equipment manufacturers for a total of over 600 members. See <http://www.etsi.org>. See also ANDREAS NEUMANN, "The European Regulatory Framework for Standardisation in the Telecommunications Sector" in CHRISTIAN KOENIG, ANDREAS BARTOSCH and JENS-DANIEL BRAUN (eds.), EC Competition and Telecommunications Law, The Hague/London/Boston: Kluwer Law International, 2002, pp. 617-690, at pp. 665-684.

${ }^{344}$ Directive 88/301/EEC of 16 May 1988 on competition in the markets for telecommunications terminal equipment, OJ L 131/73, 27 May 1988. 
(ii) Commission Directive 90/388/EEC on competition in the markets for telecommunication services $^{345}$ had a structure similar to the above Directive. It provided for the removal of special and exclusive rights granted by Member States for the supply of all telecommunication services other than voice telephony, ${ }^{346}$ telex, mobile communications, radio paging and satellite services and for objective, non-discriminatory and transparent licensing procedures. Member States that maintained monopolies for the provision and operation of public telecommunications networks were required to open them up to third-party service providers on objective and non-discriminatory published terms.

\subsubsection{THE USE OF ARTICLE 86(3) OF THE EC TREATY}

Given the political significance of these two Directives as regards their substance, but arguably even more as regards the nature of the legal act taken, i.e. through use of Article 86(3) EC, both decisions were challenged before the Court of Justice. Article 86(3) EC is, notably, a rule within the EC Treaty competition rules' structure that confers, atypically, a specific legislative competence upon the European Commission and does not grant the Member States the possibility to interfere, thus providing a direct way for Commission's action. ${ }^{347}$ The outcome of the legal challenges was therefore vital for the further Commission's measures and the overall Community telecommunications policy. In its Judgment of 19 March 1991 on the Terminal Equipment Directive ${ }^{348}$ and the later Judgment of 17 November 1992 on the Services Directive, ${ }^{349}$ the Court confirmed the legality of the Directives in all essential points. ${ }^{350}$ The ruling of the Court in the Terminal Equipment case ${ }^{351}$ strengthened the legal basis of Article 86(3) EC as a "specification in general terms of obligations arising under the Treaty ${ }^{\text {"352 }}$ and its 1990.

${ }^{345}$ Directive 90/388/EEC of 28 June 1990 on competition in the markets for telecommunications services, OJ L 192/10, 24 July

${ }^{346}$ It was deemed necessary at that stage that voice telephony would not yet be liberalised because of its special social importance and because of the danger of financially disrupting the incumbents. However, by defining the term "voice telephony" narrowly, the Directive allowed for the liberalisation of telephony services other than those provided for the general public (e.g. voice services for corporate communications and all data services), thus providing a good basis for the operation of independent Internet Service Providers and the introduction of the internet in the EC later. In January 1998, the Commission confirmed in a Notice (see Status of voice communications on the Internet under Community Law, and in particular, pursuant to Directive 90/388/EEC, OJ C 6/4, 10 January 1998) that under the definition of the Services Directive, voice on the Internet could in principle not be considered as voice telephony because it did not match the criteria set out in this definition. This ensured a fairly liberal regime for internet related services. For extensive comment on the narrow definition of "voice telephony" and its impact, see PIERRE LAROUCHE, supra note 8, at pp. 10-14.

347 See RICHARD WHISH, supra note 15, at pp. 237 et seq.

348 Case C-202/88 France v. Commission (Terminal Equipment) [1991] ECR 1223, [1992] 5 CMLR 552. See PIERRE LAROUCHE, supra note 8, at pp. 48 et seq. and footnote 43 therein for additional references on the Terminal Equipment case.

349 Joined Cases C-271/90, 281/90 and C-289/90 Spain and others v. Commission (Services) [1992] ECR 5833, [1993] 4 CMLR 100. On the issue of the proper legal basis, this ruling essentially followed the Terminal Equipment judgment.

${ }^{350}$ FrANÇOISE BLUM, "The Recent Case Law of the European Court of Justice on State Monopolies and its Implication for Network Industries" (2000) Journal of Network Industries, Vol. 1, pp. 55-87, at pp. 57 et seq. and 75 et seq.

351 The ECJ followed neither the Member States' nor the Commission's suggestions as to the relationship between Articles 86(3), 95 and 226 EC. First of all, the Court distinguished directives under Article 86(3) EC from infringement proceedings under Article 226 EC, finding that the former were "specification in general terms" of obligations arising from the Treaty. Secondly, the ECJ refused to draw a line between Articles 86(3) and 95 EC, finding that their respective subject matter, even if different, did not preclude overlap between them.

352 Case C-202/88 France v. Commission (Terminal Equipment), supra note 348, at para. 17. 
link with Article 95 EC (i.e. the normal legal basis for the adoption of internal market instruments). From the Commission's point of view, three conclusions were drawn from these judgments of significance to the further development of European Community's telecommunications policy: Firstly and in a more general context, the Court, established that a monopoly could be found illegal under Community law ${ }^{353}$ (in contrast to the previous per se legality of monopolies). ${ }^{354}$ Secondly, the Court confirmed the Commission's power to adopt directives under Article 86(3) EC in order to clarify obligations of the Member States deriving from Article 86(1) EC, stating that this power could go as far as requiring a Member State to withdraw special and exclusive rights. ${ }^{355}$ Thirdly, the Court asserted that where the withdrawal of special or exclusive rights can be required, the Commission could also set out the conditions in order to make the abolition of these special and exclusive rights effective.

It should, however, be noted that the Commission's powers under Article 86 EC were not found absolute but rather circumscribed. In the Telecommunications Services Directive case, ${ }^{356}$ the Court held that, although the Commission had power under Article 86 EC to proscribe State measures, it was not entitled under that provision to require the removal of obstacles of competition arising from contracts that have been concluded by private companies prior national legislation. In addition, the Court pointed out that the Commission could withdraw special and exclusive rights only if it defined specifically the type of rights concerned and how they were contrary to the provisions of the Treaty.

In political terms, the above development made it possible to link the liberalisation measures with the general policy measures for the telecommunications sector and ensure the creation of a coherent framework at Community level. This also allowed the Commission to take a highly pro-active stance ${ }^{357}$ with regard to further application of Article 86(3) EC instruments for advancing the liberalisation of telecommunications markets. The informal agreement reached between the Commission and the Member States - the so-called Compromise of December $1989^{358}$ - contributed to the future agreeable political atmosphere facilitating the following liberalisation endeavours.

${ }^{353}$ Although the Court of Justice did not explain why a monopoly previously conceived as legal was regarded as contrary to Articles 86 and 28 EC. See FRANÇOISE BLUM, supra note 350.

${ }^{354}$ Case 155/73 Sacchi [1974] ECR 409, [1974] 2 CMLR 177.

355 Going well beyond the approach in the first Commission Directive based on Article 86(3) EC - Commission Directive 80/723/EEC of 25 June 1980 on the transparency of financial relations between Member States and public undertakings, OJ L 195/35, 29 August 1980.

356 See supra note 349.

357 The Commission assumed a role that in the words of Herbert Ungerer was "far beyond the traditional role played by it under the EU competition rules" (HERBERT UNGERER, "EU Competition Law in the Telecommunications, Media and Information Technology Sectors" in BARRY E. HAWK (ed.), The Fordham Corporate Law Institute Annual Proceedings, New York: Juris Publishing, 1996, at p. 1). Paul Nihoul and Peter Rodford notice further that, "[t]he position adopted by the ECJ substantially modified the rapport de forces between the Commission and the Member States. The ECJ in fact rules that a legislative power was vested in the Commission to apply Treaty provisions to public monopolies" (see PAUL NIHOUL and PETER RODFORD, supra note 4, at para. 1.107). Indeed, thereupon, the Commission used all the measures available according to the EC Treaty to stimulate the Member States to adopt timely the liberalisation and harmonisation measures and stringently monitored the process.

358 See European CounCIL, Press Release 253/89 of 7 December 1989. According to the Compromise of December 1989, the Commission agreed to seek the support of the Member States for the substance of its Article 86(3) EC Directives before enacting them. 


\subsubsection{FURTHER LIBERALISATION MEASURES}

The subsequent regulatory opening up of the telecommunications markets was undertaken on a step-by-step basis, following particularly the strategy developed in the 1992 Review of the Telecommunications Sector. ${ }^{359}$ From 1994 onwards, the Satellite, ${ }^{360}$ Cable ${ }^{361}$ and Mobile Directives $^{362}$ were adopted - all of them as amendments to the Services Directive, in order to minimise the political and legal risks of destabilising the process. These Directives can be seen as logical extensions of the original Telecommunications Services Directive, which relatively rapidly liberalised substantial junks of the Community telecommunications sector.

The ultimate step of the liberalisation process was undertaken through the Full Competition Directive. ${ }^{363}$ It lifted all remaining exclusive and special rights in the sector in particular for public voice telephony and public telecommunications networks by 1 January $1998^{364}$ and provided for the liberalisation, by 1 July 1996, of the use of alternative infrastructures (such as networks of railway, power and water distribution companies) for the provision of telecommunications services other than public voice telephony. ${ }^{365}$

\subsubsection{THE OPEN NETWORK PROVISION FRAMEWORK}

If liberalisation and competition were, however, introduced in an environment of inherited monopoly and weak regulation, competitive market forces were most likely to play an

359 EUROPEAN COMMISSION, 1992 Review of the situation in the telecommunications sector, SEC(1992) 1048, 21 October 1992, COM(1993) 159 final, 28 April 1993. The results of this report formed later the core of the Bangemann Report (Europe and the Global Information Society: Report of the High Level Group on the Information Society, May 1994, European Commission, EUROP 1994), which advised the European Council for a break with the past, ending monopolies, making rapid progress towards fully liberalised environment and adopting a strategic approach towards the Information Society.

${ }^{360}$ Commission Directive 94/46/EEC amending Directive 90/388 and Directive 88/301 in particular with regard to satellite communications, OJ L 268/15, 19 January 1994. The directive provided for the withdrawal of all special and exclusive rights granted by the Member States on satellite earth station equipment and ensured the possibility of connection of satellite earth station equipment to the public telecommunications network where it satisfies the relevant common technical regulations. Member States were required to abolish the regulatory prohibitions or restrictions on the offer of space-segment capacity to any authorised satellite earth station network operator.

${ }^{361}$ Commission Directive 95/51/EC amending Directive 90/388/EEC with regard to the abolition of the restrictions on the use of cable television networks for the provision of already liberalised telecommunications services, OJ L 256/49, 26 October 1995. The directive provided for the abolition of restrictions on the use of transmission capacity on cable television networks for all telecommunications services, apart from voice telephony, from 1 January 1996 and ensured that cable television networks are allowed to interconnect with national public telecoms networks and with each other directly.

362 Commission Directive 96/2/EC amending Directive 90/388/EEC with regard to mobile and personal communications, OJ L 20/59, 26 January 1996. The directive aimed at ensuring fair competition as regards both the granting of licences to operators and the management of mobile telephony networks. Member States were required to abolish all exclusive rights in the field of mobile telecommunications and to put into place, if they have not already done so, authorisation procedures for granting licences. It also called on Member States to allow new entrants to offer their services via their own infrastructures or via alternative infrastructures to prevent high tariffs and excess capacity.

${ }^{363}$ Commission Directive 96/19/EC amending Directive 90/388/EEC with regard to the implementation of full competition in telecommunications markets, OJ L 74/13, 22 March 1996.

364 This is notably the same date scheduled for the entry into force of the Fourth Protocol to GATS that provided for the liberalisation of basic telecommunications services in the realm of the World Trade Organization.

365 The Full Competition Directive envisaged that those Member States with less well-developed or small telecommunications networks could request a temporary derogation from the liberalisation timetable of the Directive. Five such derogations were passed - for Ireland, Portugal, Luxembourg, Spain and Greece. These were subsequently shortened and have all now expired. 
extremely modest role. ${ }^{366}$ To rectify the existing imbalance of power between historic monopolists and new market players, the above mentioned liberalisation measures were accompanied by harmonisation Directives. They were adopted under Article 95 EC (ex Article 100a) ${ }^{367}$ and created the extensive Open Network Provision (ONP) framework for European Community telecommunications markets. ${ }^{368}$

While, the liberalisation Directives based on Article 86 EC had provided for continuously increasing competition up to the Full Competition Directive, the ONP Directives provided accordingly for certain restrictions imposed on the conduct of the incumbent telecommunications operators in order to preclude ex ante abuse of the dominant position, the grant of exclusive or special rights had previously conferred upon them. At that moment, the situation in the European telecommunications markets was such that the simple removal of the special and exclusive rights from the incumbent did not of itself mean competition and multitude of market players. The market transformation from monopoly to competition had to be guided and this guidance was provided by the sector specific rules of the ONP. They prescribed asymmetric rules - heavier regulation and special obligations for the historic monopolists and respectively, a lighter regime for the new players.

The ONP model had a three-tier structure. The ultimate addressees of the ONP framework and subject to the heaviest regulatory obligations were the so-called "organisations which have significant market power". ${ }^{369}$ These SMP undertakings were defined through a "bright line" rule,

\footnotetext{
${ }^{366} \mathrm{~A}$ real life example in that regard is New Zealand, where the liberalisation process was initially undertaken through application of antitrust rules only.

367 Article $95 \mathrm{EC}$ is the provision enabling the introduction of measures for the establishment and functioning of the internal market.

368 The ONP framework consisted of the following Directives:

Council Directive 90/387/EEC of 28 June 1990 on the establishment of the internal market for telecommunications services through the implementation of open network provision, OJ L 192/1, 24 July 1990, as amended by Directive 97/51/EC of 6 October 1997 amending Council Directives 90/387/EEC and 92/44/EEC for the purpose of adaptation to a competitive environment in telecommunications, OJ L 295/23, 29 October 1997.

Directive 97/13/EC of 10 April 1997 on a common framework for authorisations and individual licences in the field of telecommunications services, OJ L 117/15, 7 May 1997.

Directive 97/33/EC of 30 June 1997 on interconnection in telecommunications with regard to ensuring universal service and interoperability through application of the principles of the Open Network Provision (ONP), OJ L 199/32, 26 July 1997.

Council Directive 92/44/EEC on the application of open network provision to leased lines, OJ L 165/27, 19 June 1992 as amended by Directive 97/51/EC of 6 October 1997 amending Council Directives 90/387/EEC and 92/44/EEC for the purpose of adaptation to a competitive environment in telecommunications, OJ L 295/23, 29 October 1997.

Directive 95/47/EC of 24 October 1995 on the use of standards for the transmission of television signals, OJ L 281/51, 23 November 1995.

Directive 98/10/EC of 26 February 1998 on the application of Open Network Provision (ONP) to voice telephony and on universal service for telecommunications in a competitive environment, OJ L 101/24, 1 April 1998.

Directive 97/66/EC of 15 December 1997 concerning the processing of personal data and protection of privacy in the telecommunications sector, OJ L 24/1, 30 January 1998.

In addition to the above, some wireless/mobile instruments were also adopted: Council Directive 87/372/EEC of 25 June 1987 on the frequency bands designed for the co-ordinated introduction of public pan-European cellular digital land-based mobile communications in the European Community, OJ L 196/85, 17 July 1987; Council Directive 90/544/EC of 9 October 1990 on the frequency bands designed for the co-ordinated introduction of pan-European land-based public radio paging in the Community (ERMES), OJ L 310/28, 9 November 1990; Council Directive 91/287/EC of 3 June 1991 on the frequency band designed for the coordinated introduction of digital European cordless communication (DECT) into the Community, OJ L 144/45, 8 June 1991.

${ }^{369}$ As defined by Council Directive 92/44/EEC of 5 June 1992 on the application of Open Network Provision to leased lines, ibid. at Article 2(1).
} 
namely a market share of more than 25 per cent of the relevant market. The application of the definition was in the hands of the national regulatory authorities, which decided which telecommunications operators met this rule-of-thumb criterion. The latter were, however, free to stray from the 25 per cent benchmark and make a determination based upon the “organisation's ability to influence the market conditions, its turnover relative to the size of the market, its control of the means of access to end-users, its access to financial resources and its experience in providing products and services in the market". ${ }^{370}$ The second level of addressees, subject to some regulatory constraints, including the need to obtain an individual licence, but also benefiting from certain privileges, such as the right to interconnection, were providers of public telecommunications networks and public/publicly available telecommunications services. ${ }^{371}$ Organisations having significant market power were likely to also provide such services and networks and thus be subject to this tier of regulation as well. At the bottom of this ONP architecture was the general regulatory framework applicable to all actors on the market and to the provision of all kinds of services or networks. The latter were on the positive side of the so-created asymmetric regulatory structure and enjoyed more rights than obligations allowing them to enter and settle on the market. ${ }^{372}$

The measures imposed by the ONP Directives covered interconnection, licensing, data protection and universal service. They went beyond the measures normally imposed under Article 82 EC on dominant undertakings, laying down rules on transparency, nondiscrimination, obligations to supply and pricing. ${ }^{373}$

In the context of the above, to use the words of Edward Pitt, "...various steps have been taken to stimulate competition and assist market entry - or to recast the rather overused analogy, to make sure that the level playing field was not level and that the ex-monopolist [...] should be playing rugby uphill, into the wind and rain". 374

As a conclusion, it may be noted that the ONP could be seen as implementing in the regulatory field the liberalising drive of Article 86 EC Directives. ${ }^{375}$ These two facets of the EC telecommunications policy and law should not be thus regarded as merely co-existing beside one another. ${ }^{376}$ They should be rather perceived as overlapping and interacting with each other, whereby liberalisation measures taken by the Commission gave the impetus and served as a reference for the harmonisation measures, enacted later by the Council and the European

${ }^{370}$ Directive 92/44, Article 2(3), as replaced by Directive 97/51, Article 2(3); Directive 97/33, Article 4(3); Directive 98/10 Article 2(2)(i), see supra note 368 .

${ }^{371}$ For the corresponding definitions and their interpretation, see PIERRE LAROUCHE, supra note 8, at pp. 27 et seq.

372 The above paragraph is based on PIERRE LAROUCHE, ibid. at pp. 29-30.

373 Access Notice, at para. 15.

374 EDWARD PITT, "Competition Law in Telecommunications" in IAN WALDEN and JOHN ANGEL (eds.), Telecommunications Law, London: Blackstone Press, 2001, pp. 249-278, at p. 252 (emphasis added).

375 VASSILIS Hatzopoulos, "L'Open Network Provision (ONP) - Moyen de la dérégulation" (1994) Revue Trimestrielle de Droit Europèen, Vol. 30, at p. 63, as referred to by KLAUS W. GREWLICH, "Cyberspace: Sector-Specific Regulation and Competition Rules in European Telecommunications" (1999) Common Market Law Review, Vol. 36, pp. 937-969, at p. 951.

376 A view suggested, e.g. by ANDREAS BARTOSCH, „Europäisches Telekommunikationsrecht im Jahr 1998“ (1999) Europäische Zeitschrift für Wirtschaftsrecht, pp. 421-428, at p. 421. 
Parliament. 377 The overall success of the European Community's telecommunications liberalisation exercise was precisely due to this mix of deregulation and regulation.

\subsubsection{RELATIONSHIP BETWEEN EC COMPETITION LAW AND THE SECTORAL RULES}

During the transition period from monopoly to competition, it is important to bear in mind that the liberalisation and harmonisation packages did not exhaust the applicable law to European telecommunications. As already stressed, the ECJ made it clear from the very outset of telecommunications restructuring in the British Telecommunications case that the competition rules of the EC Treaty were also fully applicable to the sector. ${ }^{378}$ They represented, in that sense, the first pillar of the so-called "dual regime" of regulation that was applied to European Community communications markets. ${ }^{379}$

The European Commission has clearly stated in that regard that, "competition rules continue to apply in circumstances where other Treaty provisions or secondary legislation are applicable [...]. The internal market and competition provisions of Community law are both important and mutually reinforcing for the proper functioning of the sector". ${ }^{380}$ The Commission added further in the Access Notice that, "[g]iven the detailed nature of ONP rules and the fact that they may go beyond the requirements of Article 86 [now Article 82 EC], undertakings operating in the telecommunications sector should be aware that compliance with the Community competition rules does not absolve them of their duty to abide by obligations imposed in the ONP context, and vice versa" ${ }^{381}$

A clear example for the latter vice versa case, i.e. that compliance with the sectoral rules, albeit being more definitive and detailed, does not free undertakings from their duty to abide EC competition law, is the Deutsche Telekom decision. ${ }^{382}$ Therein, the Commission found a case of margin squeeze, since the difference between the wholesale prices for unbundled access to the local loop, which Deutsche Telekom (DT) charged its competitors and the prices it charged the end-users for access to its own fixed network, was not sufficient to allow the competitors to compete with DT in the provision of end-user access over local networks. ${ }^{383}$ The Commission qualified the latter situation as an abuse of dominance through unfair prices in the sense of Article 82(2)(a) EC, most notably despite the fact that DT's local access tariffs had been approved by the German telecom regulatory authority - Regulierungsbehörde für

377 Paul Nihoul defines the relationship between the two sets of rules as one of convergence. See PAUL NIHOUL, "Convergence in European Telecommunications - A Case Study on the Relationship between Regulation and Competition (Law)" (1998/99) International Journal of Communications Law and Policy, Issue 2, available at <http://www.ijclp.org>.

378 See supra Section 1.2.

379 See infra Figure Two.

380 Access Notice, at para. 58; Guidelines on the application of EEC competition rules in the telecommunications sector, supra note 29, at paras 15 and 16. See also Case IV/M.993 Bertelsmann/Kirch/Premiere, OJ [1999] L 53/1 and Case IV/M.1027 Telekom/BetaResearch, OJ [1999] L 53/31.

381 Access Notice, at para. 22.

382 Commission Decision 2003/707/EC of 21 May 2003 relating to a proceeding under Article 82 of the EC Treaty, Case COMP/C-1/37.451, 35.578, 37.579 - Deutsche Telekom AG, OJ L 263/9, 14 October 2003.

${ }^{383} \mathrm{Ibid}$. at para. 57. 
Telekommunikation und Post (RegTP). ${ }^{384}$ The Commission reaffirmed thereby the principle that, "competition rules may apply where the sector-specific legislation does not preclude the undertakings it governs from engaging in autonomous conduct that prevents, restricts or distorts competition". ${ }^{385}$ The co-existence and the simultaneous application of communications specific and antitrust rules remains thus an undisputed fact in the European Community context and something that all parties to the regulatory and market processes have to reckon with. ${ }^{386}$

The figure below visualises the relevant instruments implemented for the achievement of competition in the European telecommunications sector.

\section{Figure TWO: European COMMUNity REgUlatory INSTRUMENTS APPLIED TO TELECOMMUNICATIONS}

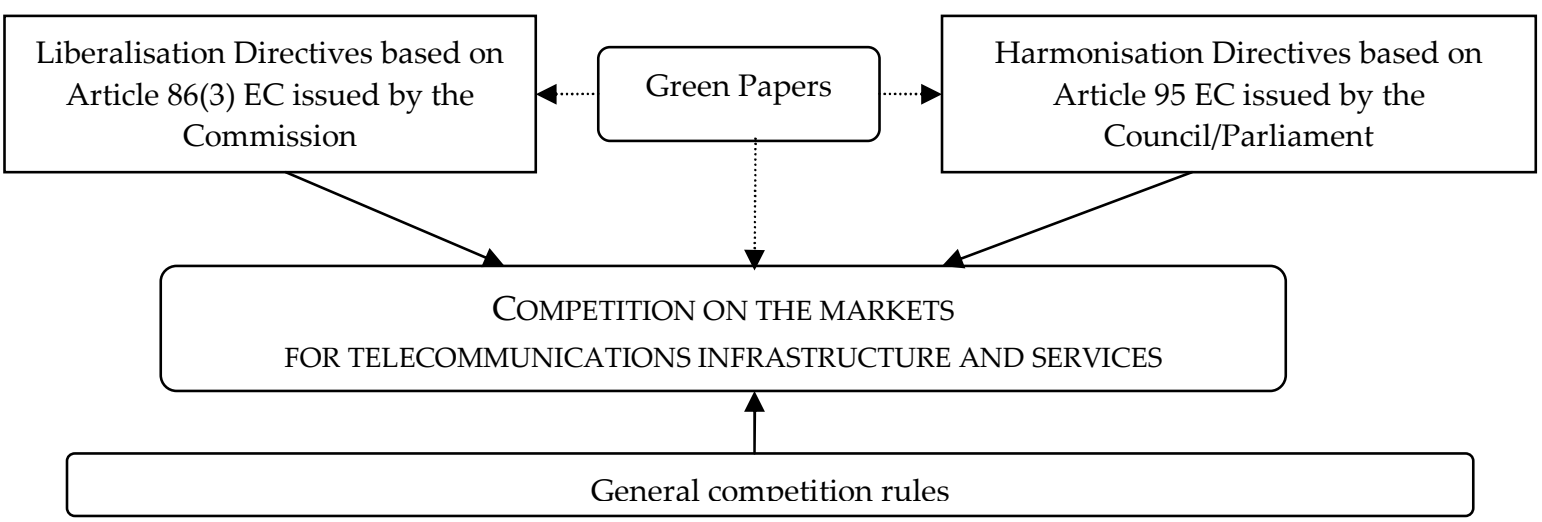

SOURCE: EUROPEAN COMMISSION 387

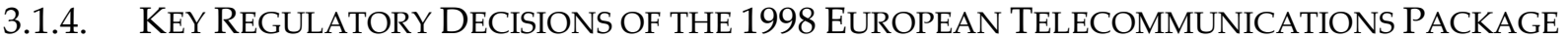

The application of the Article 86 instruments "spearheaded" 388 the liberalisation of the EC telecommunications sector and with this, of a core sector of the then still emerging Information Society. At the same time, the development demonstrated that, "the full effect of

384 Since 13 July 2005 reformed into Bundesnetzagentur für Elektrizität, Gas, Telekommunikation, Post und Eisenbahnen (BNetzA) - Federal Network Agency for Electricity, Gas, Telecommunications, Postal and Railway Markets. See $<$ http://www.bundesnetzagentur.de>.

$385 \mathrm{Ibid}$. at para. 54, referring to Joined Cases C-359/95 and C-379/95 P Commission and France v. Ladbroke Racing [1997] ECR I6225, at para. 34, with further references; Case T-228/97 Irish Sugar v. Commission, supra note 168, at para. 130; Case T-513/93 Consiglio Nazionale degli Spedizionieri Doganali v. Commission [2000] II-1807, at paras 59-60.

${ }^{386}$ Interestingly, there has been an opposite development in the US In the case of Trinko, the US Supreme Court suggested with regard to the interface between competition law and sector specific regulation that, where "a regulatory structure designed to deter and remedy anti-competitive harm [...] exists, the additional benefit provided by antitrust enforcement will tend to be small, and it will be less plausible that the antitrust laws contemplate such additional scrutiny". See Trinko, supra note 201, at p. 12. On the question of whether an analogy to EC context is possible and justified, see DAMIEN GERADIN, supra note 196, at pp. 1546 et seq.

387 Available at <http://europa.eu.int/information_society/policy/ecomm/history/index_en.htm>.

${ }^{388}$ An expression used by Pierre Larouche. See PIERRE LAROUCHE, supra note 8, at p. 40. 
the EU competition law in this respect could only be achieved by carefully correlating the measures with the development of the general regulatory framework and the build-up of a national 'regulatory infrastructure'. The approach was based on the conviction that the objectives at EC level of liberalising sectors must be internalised into Member States political and regulatory structures to create the necessary base and the 'political mass' required for major liberalisation exercises". ${ }^{389}$ As stated by the Commission in the Fifth Report on the Implementation of the Telecommunications Regulatory Package, "the combination of sectorspecific legislation and application of competition rules has worked well. Indicators of market activity demonstrate the existence of thriving and rapidly evolving telecommunications markets in the Member States". ${ }^{390}$ The transformation from monopoly to competition of the European Community's communications sector was indeed a success. ${ }^{391}$

Having in mind the foregoing and our task to examine the current regime of European Community telecommunications regulation, we shall not engage in a full-scale analysis of the 1998 framework. ${ }^{392}$ However, it is of particular significance to lay emphasis on a few of its key features, so we could clearly discern the regulatory decisions and the novelty of the 2002 package. These could be summarised (in random order) as follows:

- $\quad$ cumulative application of sector specific regulation and competition rules;

- $\quad$ special (with more restrictions and obligations) rules for the operators with significant market power, which in most of the cases happened to be the former Public Telecommunications Operators;

- there was an automatic link between the designation of SMP and the specific obligations;

- $\quad$ SMP for the purposes of sector specific regulation was not identical with the concept within the competition law practice of the European Court of Justice and the Court of First Instance, but rather based on a simplified "bright line" rule of 25 per cent market share;

- markets for the purposes of sector specific regulation were pre-defined in the Directives. No additional market definition was conducted;

389 HeRBERT UNGERER, “Use of EC Competition Rules in the Liberalisation of the European Union's Telecommunications Sector: Assessment of Past Experience and Conclusions for Use in Other Utility Sectors“, speech, Brussels, 6 May 2001, at p. 7.

390 EUROPEAN COMMISSION, Towards a new framework for electronic communications infrastructure and associated services: the 1999 Communications Review, $\operatorname{COM(1999)} 539$ final, 10 November 1999, at p. 4, summarising the pertinent conclusions of the Fifth Report on the implementation of the telecommunications regulatory package, COM(1999) 537 final, 10 November 1999.

${ }^{391}$ On the reasons for the success of the liberalisation exercise in European Community telecommunications and the active role of the Commission, see HERBERT Ungerer, "Access Issues under EU Regulation and Antitrust Law: The Case of Telecommunications and Internet Markets", Incidental Paper, Program on Information Resources Policy, Harvard University, July 2000, available at $<\mathrm{http} / / /$ www.pirp.harvard.edu>, at pp. 12-13. For the factual data proving the development of competitive EC communications markets, see e.g. EUROPEAN COMMISSION, European Electronic Communications Regulation and Markets 2004, supra note 120, Vol. I, at pp. 45-66.

${ }^{392}$ For an excellent analysis of the previous EC telecommunications regime and its development, see PIERRE LAROUCHE, supra note 8 , especially at pp. 1 et seq. 
- $\quad$ once an operator was designated as one having SMP, the whole package of remedies was automatically imposed upon it. The national regulatory authorities had no discretion to choose among the different remedies available;

- the remedies imposed were normally heavier than those available under competition rules.

\subsection{THE 2002 ElECTRONIC COMMUNICATIONS FRAMEWORK}

The accomplishment of the liberalisation process was not an end in itself. Namely because of its success, the rapid technological advances and the ever more pronounced convergence, the new situation of the telecommunications sector demanded to be reflected in a new legal framework. ${ }^{393}$ The convergence phenomenon, i.e. the ability of different network platforms to carry essentially similar services and the coming together of telecommunications, media and information technologies industries, could not be properly dealt with under the existing framework, which was based on "old" technology-based definitions and separation of the sectors' infrastructures. The need for a fresh regulatory approach was further enhanced by some persisting problems within the 1998 package, such as, inter alia, the existing disparities in the implementation of the ONP rules at national level; the comparatively low level of harmonisation, in particular of the Community licensing and interconnection regimes; the enduring dominance of the incumbents in their national markets, especially at the level of the local loop. ${ }^{394}$ There was a manifest need for a better co-ordination between general competition and sector specific rules ${ }^{395}$ and enhanced coherence in the overall regulatory regime.

In this context, building upon the Green Paper on convergence ${ }^{396}$ and the extensive follow-up consultations, ${ }^{397}$ on 10 November 1999, the Commission presented the 1999 Communications

393 This was also an obligation for the Commission since all harmonisation Directives within the ONP framework included a review clause. See e.g. Article 23 of Directive 97/13/EC on a common framework for authorisations and individual licences in the field of telecommunications services, supra note 368 .

394 Despite the overall success of the liberalisation process, the markets for the so-called "last mile" of the telecommunications networks remained under incumbents' control in a predominant number of the Member States with unsatisfactory level of competition. This, at a later stage, required the adoption of Regulation (Regulation EC/2887/2000 on unbundled access to the local loop, OJ L 336/4, 30 December 2000) in order to facilitate the solving of the "local loop unbundling" predicament and stimulate competition in these segments of the European telecommunications market. For a complete list of the identified problems to be remedied, see Fifth Report on the implementation of the telecommunications regulatory package, supra note 390, at pp. 2 et seq. See also Herbert Ungerer, supra note 391, at pp. 16-17 and PIERrE A. BuIGUES, “The Competition Policy Approach“ in PIERRE A. BUIGUES and PATRICK REY (eds.), The Economics of Antitrust and Regulation in Telecommunications, Cheltenham, UK: Edward Elgar Publishing, 2004, pp. 9-26, at pp. 11-15.

395 See e.g. PAUl NiHOUl and PETER RODFORD, supra note 4, at paras 1.122 et seq.

396 Green Paper on the convergence of the telecommunications, media and information technology sectors, and the implications for regulation, Towards an Information Society approach, COM(1997) 623, 3 December 1997. On this key document, see Wolf SAUTER, “The EC Commission Green Paper on Regulation for Convergence" (1998) Utilities Law Review, Vol. 9, No 4, pp. 167 et seq.

397 See EUROPEAN COMMISSION, Results of the public consultation on the Green Paper [COM(1997) 623], COM(1999) 108 final, 10 March 1999. 
Review: Towards a New Framework for the Electronic Communications Infrastructure and Associated Services (hereinafter the 1999 Communications Review). ${ }^{398}$

The latter Communication identified the following trends of significance to the devising the future regulatory framework:

(i) convergence of telecommunications, broadcasting and information technology sectors;

(ii) globalisation of technologies and markets;

(iii) mergers and acquisitions changing the nature of the industry and relationships between key players;

(iv) the role of the Internet in overturning traditional market structures and blurring the distinction between voice and data transmission;

(v) improvements in processing, access and basic technologies, in particular wave division multiplexing on optical fibres and digital subscriber loops;

(vi) the emergence of wireless applications;

(vii) software re-configurable technologies designed to meet the specific local market requirements; and

(viii) the development of new technologies within the media sector, in particular digital TV. 399

Accounting for all of the above challenges, the European Commission reviewed thoroughly the 1998 telecommunications framework and considered the need to allow electronic infrastructure and services of all kinds to be provided, insofar as possible, under one regulatory umbrella. ${ }^{400}$ The Commission took also the view that the future regulatory obligations should be (i) legally certain; (ii) kept to a minimum necessary to meet clearly defined objectives; (iii) be technologically neutral and that (iv) enforcement should be as close as possible to the activity being regulated. ${ }^{401}$

\footnotetext{
${ }^{398}$ EUROPEAN COMMISSION, Towards a new framework for electronic communications infrastructure and associated services: the 1999 Communications Review, supra note 390.

399 The 1999 Communications Review, at pp. 1-2.

400 The Green Paper stressed upon the possible far-reaching effects of the convergence phenomenon. The Paper did not however automatically assume that convergence at one level inevitably leads to the same degree of convergence at other levels. Equally, it made no assumption that convergence in technologies, industries, services and/or markets will necessarily imply a need for a uniform regulatory environment. If it were, nevertheless, to be established that there was need to consider changes to overall regulatory approach in the face of trends towards convergence, the Green Paper outlined the options for regulatory development. These options fell into three broad groups, namely: (i) building on the current structures, i.e. the existing separate regulatory frameworks for telecommunications and broadcasting are preserved and extended on an ad hoc basis, principally at national level, to meet the demands of a competitive market and the challenges of new technologies and services; (ii) developing a separate regulatory model for new activities to co-exist with telecommunications and broadcasting regulation; and (iii) progressively introducing a new regulatory model to cover the whole range of existing and new services After a first round of consultations, the Commission concluded that the first option was the most favoured by the interested parties. A second round of consultations led to the conclusion, among others, that the regulation of infrastructure should be separated from that of content, and that sector specific regulation should be phased out as markets become more competitive and can be left to the general rules of competition law alone. For a critical analysis of the Green Paper on convergence, see MARK NAFTEL and LAWRENCE J. SPIWAK, The Telecoms Trade War: The United States, the European Union and the World Trade Organization, Oxford/Portland, Oregon: Hart Publishing, 2000, at pp. 345-348.

4011999 Communications Review, at pp. 12-14.
} 
The 1999 Communications Review gave the basis for the new regulatory regime and envisaged the lines along which it should be built. It stated that the new framework will seek to reinforce competition in all market segments, particularly at local level and that it should be designed to cater for new, dynamic and largely unpredictable markets with many more players than today. In this sense, the Commission declared its willingness to give up the "crude but potentially effective toolkit" 402 of the 1998 communications package. It sought rather a light regulatory approach for new services markets, while ensuring that dominant operators do not abuse their market power. Regulation implemented as a proxy for competition was to be reduced as markets become more competitive and it would thereby be limited to areas where policy objectives cannot be achieved by competition only. The dual regime, i.e. application of sector specific regulation and competition rules was however not abolished. It was preserved as such but the sector specific rules were given a new antitrust design. Furthermore, market-by-market sunset clauses were included to trigger the withdrawal of the sectoral rules once the defined markets were found to have achieved the necessary level of competition. ${ }^{403}$

\subsubsection{DESIGN OF THE NEW REGULATORY FRAMEWORK}

\subsubsection{1. "HARD LAW" INSTRUMENTS}

The 2002 EC regulatory regime for electronic communications simplifies substantially the previous one - the applicable Directives are reduced from some twenty-six to six. ${ }^{404}$ They comprise one Framework Directive and four Specific Directives adopted on the basis of Article 95 EC by the Council and the European Parliament and one Commission Directive. ${ }^{405}$ The latter Directive prescribes that only those provisions from the previous liberalisation instruments that are necessary for maintaining liberalisation need to be retained. ${ }^{406}$ It imposes,

${ }^{402}$ MARTIN CAVE, "Economic Aspects of the New Regulatory Regime for Electronic Communications Service" in PIERRE A. BUIGUES and PATRICK ReY (eds.), The Economics of Antitrust and Regulation in Telecommunications, Cheltenham, UK: Edward Elgar Publishing, 2004, pp. 27-41, at p. 27.

${ }^{403}$ See infra Section 3.2.4.

${ }^{404}$ For a visualisation of the design of the 2002 regulatory package as compared to that of 1998, see infra Figure Three.

${ }^{405}$ Commission Directive 2002/77/EC of 16 September 2002 on competition in the markets for electronic communications networks and services, OJ L 249/21, 17 September 2002.

406 The Directives repealed by the new Commission's instrument are: Commission Directive 90/388/EEC of 28 June 1990 on competition in the markets for telecommunications services, supra note 345; Articles 2 and 3 of Commission Directive 94/46/EEC amending Directive $90 / 388$ and Directive $88 / 301$ in particular with regard to satellite communications, supra note 360; Commission Directive 95/51/EC amending Directive 90/388/EEC with regard to the abolition of the restrictions on the use of cable television networks for the provision of already liberalised telecommunications services, supra note 361; Commission Directive 96/2/EC amending Directive 90/388/EEC with regard to mobile and personal communications, supra note 362; Commission Directive 96/19/EC amending Directive 90/388/EEC with regard to the implementation of full competition in telecommunications markets, supra note 363; Commission Directive 99/64/EC amending Directive 90/388 in order to ensure that telecommunications networks and cable TV networks owned by a single operator are separate legal entities, OJ L 175/39, 10 July 1999. Directive 88/301/EEC on competition in the markets for telecommunications terminal equipment (OJ L 131/73, 27 May 1988) is notably not repealed by the new Commission Directive. The new regulatory regime contains however few rules regarding equipment and aimed ensuring interoperability of digital equipment in the face of convergence. See in particular, Article 24 and Annex VI of the Universal Service Directive and Article 18 of the Framework Directive. 
in fact, no additional obligations for the Member States ${ }^{407}$ but stresses the abolition of exclusive and special rights and clarifies the transition from the old to the new regulatory framework, especially in terminological terms.

The Framework Directive ${ }^{408}$ is the core document of the new regime. It establishes a harmonised framework for the regulation of electronic communications services, electronic communications networks and associated facilities. It contains the key principles, sets out the structure of the regime as a whole and clarifies the status and obligations of the National Regulatory Authorities (NRAs). The Specific Directives, essentially as being such, build upon the basis given by the Framework Directive, and regulate on different aspects of electronic communications networks and services.

These specific measures are:

- Directive 2002/20/EC of the European Parliament and of the Council of 7 March 2002 on the authorisation of electronic communications networks and services (hereinafter the Authorisation Directive); 409

- Directive 2002/19/EC of the European Parliament and of the Council of 7 March 2002 on access to, and interconnection of, electronic communications networks and associated facilities (hereinafter the Access Directive);

- Directive 2002/22/EC of the European Parliament and of the Council of 7 March 2002 on universal service and users' rights relating to electronic communications networks and services (hereinafter the Universal Service Directive); 411

\footnotetext{
407 The only additional obligations are those contained in Article 7. The latter concerns satellites and requires Member States to ensure the abolition of regulatory restrictions on the offering of space segment capacity to any authorised satellite earth station network operator.

${ }^{408}$ Directive 2002/21/EC of the European Parliament and of the Council of 7 March 2002 on a common regulatory framework for electronic communications networks and services (Framework Directive), OJ L 108/33, 24 April 2002. The Framework Directive effectively replaces the ONP Framework Directive (Directive 90/387/EEC on the establishment of the internal market for telecommunications services through the implementation of open network provision, supra note 368) and repeals Council Decision 91/396/EEC of 29 July 1991 on the introduction of a single European emergency call number, OJ L 217/31, 6 August 1991; Council Directive 92/44/EEC of 5 June 1992 on the application of open network provision to leased lines, supra note 368; Council Decision 92/264/EEC of 11 May 1992 on the introduction of a standard international telephone access code in the Community, OJ L 137/21, 20 May 1992; the TV Standards Directive 95/47/EC (supra note 368); the Licensing Directive 97/13/EC (supra note 368); the Interconnection Directive 97/33/EC (supra note 368); Directive 98/10/EC on the application of open network provision (ONP) to voice telephony and on universal service for telecommunications in a competitive environment, supra note 368.

409 OJ L 108/21, 24 April 2002. The Authorisation Directive effectively replaces all existing licensing and authorisation directives and decisions: the Licensing Directive 97/13/EC (supra note 368); the GSM Directive 87/372/EEC (supra note 368); the pan-European paging (ERMES) Directive 90/544/EC (supra note 368); Recommendation 86/659/EEC the coordinated introduction of the integrated services digital network (ISDN) in the European Community, OJ L 382/36, 31 December 1986; Digital European Cordless Telecommunications (DECT) Directive 91/287/EEC (supra note 368); the Emergency Number Decision 91/396/EEC (supra note 408); the International Access Code Decision 92/264/EEC (supra note 408); and Decision 128/1999/EC on the co-ordinated introduction of a third generation mobile and wireless communications system (UMTS) in the Community, OJ L 17/1, 22 January 1999.

${ }^{410}$ OJ L 108/7, 24 April 2002. The Access Directive effectively replaces the relevant provisions of the Interconnection Directive 97/33/EC (supra note 368) and the ONP Leased Lines Directive 92/44/EEC (supra note 368) and builds upon the principles of the TV Standards Directive 95/47/EC (supra note 368).

411 OJ L 108/51, 24 April 2002. The Universal Service Directive effectively replaces the relevant provisions of the Interconnection Directive 97/33/EC (supra note 368) and the Voice Telephony Directive 98/10/EC (supra note 368).
} 
- Directive 2002/58/EC of the European Parliament and of the Council of 12 July 2002 concerning the processing of personal data and the protection of privacy in the electronic communications sector (hereinafter Directive on Privacy and Electronic Communications). ${ }^{412}$

Other measures that need to be equally considered parts of the current European Community communications regime are the Decision on radio spectrum, ${ }^{413}$ the Commission Decision on establishing the European Regulators Group, ${ }^{414}$ as well as the List of standards and/or specifications for electronic communications networks, services and associated facilities and services published in accordance with Article 17 of the Framework Directive. ${ }^{415}$ The Regulation on unbundled access to the local loop ${ }^{416}$ that introduced the requirement for providing access to the incumbents' local infrastructure ${ }^{417}$ in advance of the entry into force of the rest of the package ${ }^{418}$ is carried over into the new framework but "subject to immediate review in the light of the prevailing market conditions". ${ }^{419}$

The current framework is in force since 24 April 2002. The Member States were given a period to adopt and publish the laws, regulations and administrative provisions necessary to comply with it until 24 July $2003 .{ }^{420}$

412 OJ L 201/37, 31 July 2002. The Directive on privacy and electronic communications replaces Directive 97/66/EC concerning the processing of personal data and the protection of privacy in the telecommunications sector, supra note 368 . The e-privacy Directive was adopted a bit later than the rest of the package and the date for its transposition was set for 31 October 2003.

${ }^{413}$ Decision 676/2002/EC of the European Parliament and of the Council of 7 March 2002 on a regulatory framework for radio spectrum policy in the European Community (Radio Spectrum Decision), OJ L 108/1, 24 April 2002.

${ }^{414}$ Commission Decision of 29 July 2002 on establishing the European Regulators Group for electronic communications networks and services, OJ L 200/38, 30 July 2002, as amended by Commission Decision of 14 September 2004, OJ L 293/30, 16 September 2004.

${ }^{415}$ List of standards and/or specifications for electronic communications networks, services and associated facilities and services, OJ L 331/32, 31 December 2002.

416 Regulation 2887/2000/EC on unbundled access to the local loop, supra note 394.

417 The Regulation mandates unbundled access only to the metallic local loops of notified operators designated as having SMP. The "local loop" is defined as the physical twisted metallic pair circuit connecting the network termination point at the subscriber's premises to the main distribution frame or equivalent facility in the fixed public telephone network. The new Access Directive contains "obligations of access to, and use of, specific network facilities" (Article 12), including unbundled access to the local loop.

418 As of 31 December 2000.

${ }^{419}$ Access Directive, at Recital 12. The Framework Directive states at Recital 43 in that regard that, "[t]he Commission should monitor the transition from the existing framework to the new framework, and may in particular, at an appropriate time, bring forward a proposal to repeal Regulation (EC) No 2887/2000 of the European Parliament and of the Council of 18 December 2000 on unbundled access to the local loop".

${ }^{420}$ After the given period of time for the transposition of a Directive (which according to EC law means adoption of instruments and measures in national law, or respectively, changing the existing national law in order to achieve the goals prescribed in the Directive), the Commission has the right to invoke infringement procedures before the ECJ (Article $226 \mathrm{EC}$ ) in order to ensure that Member States comply with their obligations. Normally, such procedures have considerable political pressure and if the ECJ finds indeed the presence of infringement, heavy fees may be set in addition with the requirement to comply. On the current state of transposition of the e-communications package, see the EUROPEAN COMMISSION, European electronic communications regulation and markets 2005, COM(2006) 68 final, 20 February 2006. For the latest developments on implementation and infringement procedures, <http://europa.eu.int/information_society/policy/ecomm/implementation_enforcement/index_en.htm>. 
FIGURE THREE: DESIGN OF THE 2002 FRAMEWORK

\section{ARTICLE 95 DIRECTIVES ${ }^{421}$}

\begin{tabular}{|l|l|}
\hline $\begin{array}{l}\text { ONP Framework Directive (90/387/EEC } \\
\text { omandad hr } 07 / 51 / \mathrm{FC})\end{array}$ & Framework Directive \\
\hline
\end{tabular}

\begin{tabular}{|l|l|l|}
\hline Licensing Directive (97/13/EC) \\
\hline GSM Directive (87/372/EEC) & \\
\hline ERMES Directive (90/544/EC) & \\
\hline DECT Directive (91/287/EC) & & \\
\hline
\end{tabular}

\begin{tabular}{|l|l|}
\hline ONP Leased Lines Directive (92/44/EEC \\
\hline TV Standards Directive (95/47/EC) \\
\hline Interconnection Directive (97/33/EC) \\
\hline Voice Telephonv Directive (98/10/EC) \\
\hline
\end{tabular}

\begin{tabular}{|lll|l|}
\hline Telecoms & Data & Protection & Directive \\
\cline { 3 - 3 }
\end{tabular}

\section{ARTICLE 86 DIRECTIVES 422 $^{2}$}

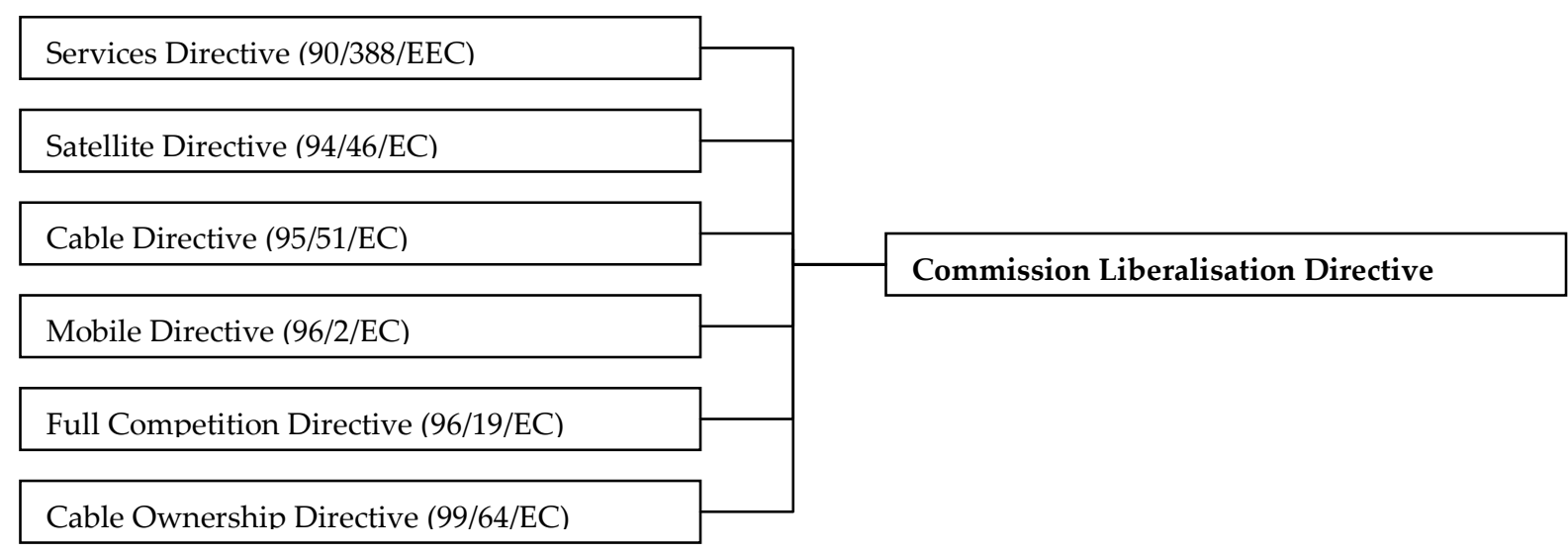

\footnotetext{
${ }^{421}$ For the full names of the Directives and the precise references, see supra note 368 .

422 For the full names of the Directives and the precise references, see supra Section 3.1.1 and note 406.
} 


\subsubsection{2. "SOFT LAW" INSTRUMENTS}

In the pursuit of legal certainty, the design of the new framework for electronic communications includes also certain soft-law instruments as complimentary to the regulatory regime that should provide guidance and ensure consistency of the approaches. Although they are by their legal nature non-binding, ${ }^{423}$ these soft-law tools play, as we shall see below, a critical role in the functioning of the SMP mechanism. These are the Commission SMP Guidelines ${ }^{424}$ (adopted in accordance with Article 15(2) of the Framework Directive); the Relevant Market Recommendation ${ }^{425}$ (adopted by the Commission in accordance with Article 15(1) of the Framework Directive) and the more specific Recommendation on accounting separation and cost accounting. ${ }^{426}$ These measures are to be regularly updated in order to keep up with the new developments in the communications market and flexibly deal with emerging problems.

Besides the soft law measures, the synchronisation between the Member State level and the Community one in implementing the current regulatory framework is secured through the mechanism contained in Article 7 of the Framework Directive. This so-called "special regulatory procedure" 427 is indeed the primary tool for coordination between the national agencies and the Commission and crucial for the development of the internal market for electronic communications networks and services through consistent regulation and transparency. ${ }^{428}$

Article 7 prescribes a mechanism, whereby whenever the NRA intends to take a measure, which regards the critical issues of market definition and market analysis ${ }^{429}$ or imposition, amendment or withdrawal of obligations ${ }^{430}$ and this measure would affect trade between

${ }^{423}$ Guidelines as a legal instrument fall under the category of "notices" in the EC law structure. In the telecommunications sector, the Commission has already made the experience of using such a measure through the 1991 Guidelines and the Access Notice. These have no binding force but simply show the position of the European Commission and often provide a valuable digest of the existing case law. They are however without prejudice to the application of Community law and to its interpretation by the Court of Justice and the Court of First Instance. Recommendations have equally no binding force upon the Member States (Article 249(4) EC). However, any recommendation or soft law instrument should be taken into account by national authorities and national courts. See Case C-322/88 Grimaldi v. Fonds des maladies professionnelles [1989] ECR I-4407, [1991] 2 CMLR 265, at para. 18. The legal force of the Relevant Market Recommendation is further reinforced by the Article 7 Framework Directive procedure and the Commission's power to veto NRAs' measures.

424 Guidelines on market analysis and the assessment of significant market power under the Community regulatory framework for electronic communications networks and services, supra note 12.

${ }^{425}$ Recommendation on relevant product and service markets within the electronic communications sector susceptible to $e x$ ante regulation in accordance with Directive 2002/21/EC, supra note 90.

${ }^{426}$ Commission Recommendation of 19 September 2005 on accounting separation and cost accounting under the regulatory framework for electronic communications, OJ L 266/64, 11 October 2005 and accompanying Explanatory Memorandum of 19 September 2005.

427 As framed by PAUl NiHOUl and Peter RodFord, supra note 4, at p. xxxiv. On the Article 7 mechanism, see PAUl NiHOUL and PETER RODFORD, ibid. at paras 3.110 et seq. See also the SMP Guidelines, at paras 146-156 and Commission Recommendation of 23 July 2003 on notifications, time limits and consultations provided for in Article 7 of Directive 2002/21/EC of the European Parliament and of the Council of 7 March 2002 on a common regulatory framework for electronic communications networks and services, OJ L 190/13, 30 July 2003.

${ }^{428}$ EUROPEAN COMMISSION, Communication on market reviews under the EU regulatory framework: Consolidating the internal market for electronic communications, COM(2006) 28 final, 6 February 2006, at pp. 2 et seq.

${ }^{429}$ Articles 15 and 16 of the Framework Directive. See infra Sections 3.2.4.2 et seq.

${ }^{430}$ Articles 5 and 8 of the Access Directive and Article 16 of the Universal Service Directive. See infra Sections 3.2.4.4 et seq. 
Member States, the NRA must make the draft measure accessible to the Commission and the other NRAs, giving them the possibility to comment. The Commission has one month in which to assess the notification of the proposed measures. Upon the experience made in the past three years in applying the Article 7 procedure, it seems that the largest portion of cases are handled within this one month period by a letter to the NRA concerned, which normally contains the comments of the Commission as to improvement of the measures at issue. ${ }^{431}$

Further and more importantly, where the intended measure aims at: (i) defining a relevant market other than those defined in the Commission recommendation or (ii) deciding whether or not to designate an undertaking as having significant market power, and would affect trade between Member States, the Commission may veto the measure. ${ }^{432}$ A veto is given if, in the view of the Commission, the measure would create a barrier to the single market or if it has serious doubts as to its compatibility with Community law and in particular the objectives referred to in Article 8 of the Framework Directive. In this second stage of the Article 7 procedure, the Commission conducts a more detailed investigation and should its concerns be confirmed, it requires the national agency to withdraw the draft measure (i.e. exercises its veto power) and possibly asks for resubmission of the market analysis at a later stage. ${ }^{433}$

Of the 229 cases assessed by the Commission until 30 September 2005, it adopted veto decisions only in 4 cases. ${ }^{434}$ These decisions ensured that no measures were taken at the Member State level that would be incompatible with Community law and ensured, in the words of the Commission, a "coherent application of competition law principles across the EU. 435

431 EUROPEAN COMMISSION, Communication on market reviews under the EU regulatory framework: Consolidating the internal market for electronic communications, supra note 428 , at p. 3.

432 The decision of the Commission must be accompanied by a detailed and objective analysis of why the Commission considers that the draft measure should not be adopted together with specific proposals for amending the draft measure. The procedure to be followed is that of Article 22(2) of the Framework Directive.

433 EUROPEAN COMMISSION, Communication on market reviews under the EU regulatory framework: Consolidating the internal market for electronic communications, supra note 428 , at p. 3.

434 See Commission Decision of 20 February 2004 pursuant to Article 7(4) of Directive 2002/21/EC ("Withdrawal of a notified draft measure"), Case FI/2003/0024 and FI/2003/27: Publicly available international telephone services provided at a fixed location for residential and non-residential customers, C(2004) 527 final, 20 February 2004; Commission Decision of 5 October 2004 pursuant to Article 7(4) of Directive 2002/21/EC ("Withdrawal of a notified draft measure"), Case FI/2004/0082: Access and call origination on public mobile telephone networks in Finland, C(2004) 3682 final, 5 October 2004; Commission Decision of 20 October 2004 pursuant to Article 7(4) of Directive 2002/21/EC ("Withdrawal of a notified draft measure"), Case AT/2004/0090: Transit services in the fixed public telephone network in Austria, C(2004) 4070 final, 20 October 2004 and Commission Decision of 17 May 2005 pursuant to Article 7(4) of Directive 2002/21/EC ("Withdrawal of notified draft measures"), Case DE/2005/0144: Call termination on individual public telephone networks provided at a fixed location, C(2005) 1442 final, 17 May 2005 . See also LUCA Di MAURO and ANDRÁs G. INOTAI, "Market Analyses under the New Regulatory Framework for Electronic Communications: Context and Principles behind the Commission's First Veto Decision", EC Competition Policy Newsletter, No 2, Summer 2004, pp. 52 et seq. and EUROPEAN COMMISSION, Communication on market reviews under the EU regulatory framework: Consolidating the internal market for electronic communications, ibid.

435 EUROPEAN COMMISSION, Communication on market reviews under the EU regulatory framework: Consolidating the internal market for electronic communications, ibid. at p. 6. 


\subsubsection{SCOPE OF THE ELECTRONIC COMMUNICATIONS REGIME}

The scope of the current EC regime covers the regulation of electronic communications services, electronic communications networks, associated facilities and associated services. ${ }^{436}$ In essence, this means that it spreads over all transmission networks and services. The scope of the communications framework is thus wider than the one under the 1998 regulatory regime. By explicitly including all networks, broadcasting networks and the Internet, ${ }^{437}$ which were previously not part of the telecommunications regulation, now fall under it.

In contrast to the previous communications regime, the new framework pursues further a clear separation between regulation of transmission and regulation of content. The new regime focuses exclusively on the former, while content, such as broadcasting content, financial services and certain information society services, ${ }^{438}$ remain out of its scope of application. It is hence without prejudice to measures taken at Community or national level in respect of such services in order to promote cultural and linguistic diversity and to ensure the defence of media pluralism. 439

Yet, as stated in Recital 5 of the Framework Directive, this separation "does not prejudice the taking into account of the links between them, in particular to guarantee media pluralism, cultural diversity and consumer protection". Thus, one can observe that the seemingly clear separation between content and infrastructure gets somewhat blurry in particular when certain public interest goals are touched upon. There is furthermore a lack of criteria identifying when exactly "the links existing between them" should be taken into consideration and when not. The "clear" separation between content and infrastructure can be in practice problematic in its own right since the intensified convergence of media, telecommunications and information technologies, renders the boundaries between them

\footnotetext{
${ }^{436}$ For the respective definitions, see Article 2 of the Framework Directive.

${ }^{437}$ The Consolidated Commission Competition Directive specifies that the "new definitions [of electronic communications networks and services] are indispensable in order to take account of the convergence phenomenon by bringing together under one single definition all electronic communications services and/or networks which are concerned with the conveyance of signals by wire, radio, optical or other electromagnetic means (i.e. fixed, wireless, cable television, satellite networks). Thus, the transmission and broadcasting of radio and television programmes should be recognised as an electronic communication service and networks used for such transmission and broadcasting should likewise be recognised as electronic communications networks. Furthermore, it should be made clear that the new definition of electronic communications networks also covers fibre networks which enable third parties, using their own switching or routing equipment, to convey signals". See Commission Directive 2002/77/EC on competition in the markets for electronic communications networks and services, supra note 405, at Recital 7.

${ }^{438}$ As defined in Directive 98/34/EC of the European Parliament and of the Council of 22 June 1998 laying down a procedure for the provision of information in the field of technical standards and regulations, OJ L 204/37, 21 July 1998, as amended by Directive 98/48/EC, OJ L 217/18, 5 August 1998. Article 1 therein defines "information society service" as "any service normally provided for remuneration, at a distance, by electronic means and at the individual request of a recipient of services". Annex $\mathrm{V}$ of the Directive provides further an indicative list of services not covered by this definition.

${ }^{439}$ The content of television programmes is covered by Council Directive 89/552/EEC of 3 October 1989 on the coordination of certain provisions laid down by law, regulation or administrative action in Member States concerning the pursuit of television broadcasting activities, OJ L 298/23, 17 October 1989, as amended by Directive 97/36/EC, OJ L 202/60, 30 July 1997. For the review of the latter instrument, see Proposal for a Directive of the European Parliament and of the Council amending 89/552/EEC on the coordination of certain provisions laid down by law, regulation or administrative action in Member States concerning the pursuit of television broadcasting activities, COM(2005) 646 final, 13 December 2005.
} 
indiscernible. There exist cases, such as, for instance, pay-TV, which operate at the interface between technology and content. ${ }^{440}$

\subsubsection{Key ElEMENTS OF THE 2002 COMMUNICATIONS REGIME}

The underlying principles of the 2002 regulatory framework, as a distinct system within the European Community legislation, that was designed to meet the challenges identified by the 1999 Communications Review ${ }^{441}$ and ensure sustainable competition under the new technological and market conditions, can be broadly summarised as follows:

- $\quad$ extension of the framework to cover not only telecommunications but also all types of networks and services, qualifying as "electronic communications";

- $\quad$ separation of content and networks in the regulatory scheme;

- greater reliance on competition law rules as opposed to sector specific regulation, including new design of the sector specific regulation;

- $\quad$ market-by-market sunset clauses;

- new institutional balance between the Member States and the Community level;

- $\quad$ technological neutrality.

These key novel regulatory solutions have their repercussions in the texture of the whole framework for electronic communications. From a different perspective, if we adopt the classification used by Alexandre de Streel, ${ }^{442}$ the new regime could be divided into three layers of regulation according to the objectives pursued. The first layer of "entry regulation" deals with entry on the market and the allocation of scarce resources like spectrum frequencies and numbering. The second one, "social regulation", aims to ensure that the needs of the citizens that are considered important by the legislature are satisfied. Since some needs are not necessarily guaranteed by the functioning of the market, the "social regulation" provides for an enhanced consumer protection and the universality of access to some basic electronic networks and services. The third layer and the core one within the new communications regime is that of "economic regulation". It aims at ensuring the functioning of an effective competitive market, thereby maximising economic efficiency. Thus, it pursues the same goals as general competition rules, but is employed to regulate market power precisely when antitrust law would not be sufficiently effective to do so, taking into account the characteristics of the electronic communications sector, such as the inherent economies of scale and scope, network effects and the presence of historic monopolists.

Considering the overall purpose of the present work to examine to potential of EC competition law as the (hypothetical) sole regulator applied to electronic communications, the

\footnotetext{
${ }^{440}$ See NatAli Herberger, Controlling Access to Content, The Hague/London/Boston: Kluwer Law International, 2005, at p. 3.

${ }^{441}$ See supra Section 3.2 .

${ }_{442}$ AleXANDRE DE STREeL, "The Integration of Competition Law Principles in the New European Regulatory Framework for Electronic Communications" (2003) World Competition, Vol. 26, No 3, pp. 489-514.
} 
following paragraphs will concentrate on the "economic regulation" layer of regime, the epitome of which is the new significant market power regime (point three of the above list). The SMP regime has been lately the subject of some excellent studies ${ }^{443}$ but we need to see its essence in the concrete context of the present work: Firstly, because the latter regime is based on antitrust methodology and secondly, because it contains the very mechanisms that are to trigger the withdrawal of sector specific regulation and ultimately bestow the regulation of the communications sector upon EC generic competition rules.

\subsubsection{THE NEW SIGNIFICANT MARKET POWER REGIME}

\subsubsection{INTRODUCTION TO THE SMP REGIME}

The broad outlines of the SMP regime algorithm could be identified in four steps: ${ }^{444}$ (i) Firstly, the Commission adopts a Recommendation ${ }^{45}$ that defines, in accordance with the principles of competition law, the product and service markets within the electronic communications sector, the characteristics of which may be such as to justify the imposition of ex ante regulatory obligations.

(ii) Taking into account this Recommendation on relevant markets and the Commission SMP Guidelines, the NRA then defines markets appropriate to the national circumstances, in particular their geographical dimension within the Member State's territory. The NRA may stray from the Commission's selection (step (i)) and define other product/services markets, if it finds that appropriate, though the latter is subject to the review of the Commission, as we shall discover below. Taken together, steps (i) and (ii) amount to a completed market definition process, as discussed in the Section on EC competition rules above.

(iii) In a third step, the NRA analyses the so-defined markets to determine whether they are, or not, effectively competitive, which is equal to determining whether one or more operators enjoy significant market power on the market at issue. The notion of SMP is equal to that of dominance under generic EC competition law however without the need of finding an abuse.

(iv) In a fourth step, considering the foregoing, if the market is not effectively competitive, the NRA imposes on the SMP operators the appropriate specific regulatory obligations chosen from the list of options provided in the Access Directive for wholesale markets and in the Universal Service Directive for retail markets. Conversely, if the market is found to be effectively competitive, the NRA must withdraw any obligation that may be in place and shall not impose a new one.

${ }^{443}$ See Jens-Daniel Braun and Ralf CAPITO, "The Framework Directive" in Christian Koenig, ANDreas Bartosch and JENS-DANIEL BRAUN (eds.), EC Competition and Telecommunications Law, The Hague/London/Boston: Kluwer Law International, 2002, pp. 309-358; AleXANDre De Streel, supra note 442; MARTin CAVE, supra note 402; PAUl NiHOUl and Peter RodFord, supra note 4, at paras 3.213 et seq.; TAMBIANA MADIÉGA, "Innovation and Market Definition under the EU Regulatory Framework for Electronic Communications" (2006) World Competition, Vol. 29, No 1, pp. 55-72.

${ }^{444}$ See infra Figure Four.

${ }^{445}$ For the currently applicable Recommendation, see supra note 90. 
The above process is to be repeated periodically to ensure that the obligations are adapted to the market evolution in the hope that a moment will come when the Commission will find no communications markets in need of ex ante rules and the NRAs will find accordingly no SMP operators on the previously selected markets.

Even a brief, fleeting overview of this four-step process shows radical reforms in the regime if compared to the previous one: Under the 1998 regulatory package, the market areas to be regulated were pre-defined in the Directives on the basis of their technical characteristics ${ }^{446}$ and no additional market definition or market analysis were undertaken by the NRAs. Furthermore, the threshold of 25 per cent market share in these areas equated automatically to a designation of SMP. The NRAs then had to impose on the SMP operators the full set of obligations provided in the ONP Directives without being able to choose the most appropriate ones. The 2002 regime is based, in contrast, on competition law methodology, although with some important differences to generic EC competition rules as we shall see below in the course of the detailed examination of the SMP regime.

Figure Four: The Algorithm OF THE SMP REgIME

\begin{tabular}{|c|c|c|c|}
\hline \multirow{4}{*}{$\begin{array}{l}\text { A. MARKET DEFINITION } \\
\text { Article } 15 \text { of the } \\
\text { Framework Directive } \\
\text { Commission Recommendation on } \\
\text { relevant product and service markets } \\
\text { susceptible to ex ante regulation }\end{array}$} & \multirow{3}{*}{$\begin{array}{l}\text { Step } 1 \\
\text { Step } 2\end{array}$} & \multirow{3}{*}{$\begin{array}{l}\text { Market Selection } \\
\text { Market Selection (additional/ } \\
\text { not mandatory step) }\end{array}$} & \multirow{3}{*}{$\begin{array}{l}\text { By the Commission in a } \\
\text { Recommendation } \\
\text { By the NRA in a Decision } \\
\text { (subject to Article } 7 \\
\text { Framework Directive } \\
\text { procedure) }\end{array}$} \\
\hline & & & \\
\hline & & & \\
\hline & Step 3 & $\begin{array}{l}\text { Product and/or Geographical } \\
\text { Market Definition }\end{array}$ & By the NRA in a Decision \\
\hline $\begin{array}{l}\text { B. MARKET ANALYSIS } \\
\text { Articles } 14 \text { and } 16 \text { of the } \\
\text { Framework Directive }\end{array}$ & \multirow{2}{*}{\multicolumn{2}{|c|}{$\begin{array}{l}\text { Designation of one or more operators as } \\
\text { having SMP }\end{array}$}} & By the NRA \\
\hline $\begin{array}{l}\text { Commission Guidelines on market } \\
\text { analysis and the assessment of SMP }\end{array}$ & & & \\
\hline $\begin{array}{l}\text { C. CHOICE OF REMEDIES } \\
\text { Article } 16 \text { of the Framework } \\
\text { Directive, Article } 8 \text { of the Access } \\
\text { Directive, Article } 7 \text { of the Universal } \\
\text { Service Directive }\end{array}$ & \multicolumn{2}{|c|}{$\begin{array}{l}\text { In case of SMP operator(s) - Imposition, } \\
\text { maintenance or amendment of } \\
\text { appropriate obligation(s) (at least one) } \\
\text { In absence of SMP operator(s) - Removal } \\
\text { of any obligations }\end{array}$} & By the NRA \\
\hline
\end{tabular}

SOURCE: ALEXANDRE DE STREEL ${ }^{447}$

\footnotetext{
446 See Directive 98/10 and Directive 97/33, see supra note 368.

447 Based with modifications on ALEXANDRE DE STREEL, supra note 442, at p. 494.
} 
The next paragraphs will elaborate in turn on the different steps of the SMP regime algorithm.

\subsubsection{MARKET DEFINITION}

\section{A. MARKET SELECTION}

Market selection in the sense of the 2002 SMP regime resembles a preliminary "wholesale" market definition. That is to say, that although there is a multiplicity of markets in the electronic communications sector that could be singled out and defined in antitrust terms, for the purpose of the new regime, only some of them will be selected en masse and thus, subject to further analysis by the NRAs. As made clear by Article 15(1) of the Framework Directive, which is the legal basis of the Commission Recommendation on relevant markets, "[t]he recommendation shall identify [...] those product and service markets within the electronic communications sector, the characteristics of which may be such as to justify the imposition of regulatory obligations set out in the Specific Directives, without prejudice to markets that may be defined in specific cases under competition law". ${ }^{448}$ Recital 27 of the same Directive states further that this selection should be based on the characteristics of the market and more precisely on the relative efficiency of sector specific remedies compared to competition law remedies to address competition problems.

In the Relevant Market Recommendation adopted in February $2003,{ }^{449}$ the Commission has interpreted and elaborated upon these provisions by referring to three cumulative criteria that should be fulfilled for a certain market to be selected.

(i) The first criterion is static and based upon the presence of high and non-transitory barriers to entry. The barriers may be of structural, legal or regulatory nature. Structural barriers to entry may result from original cost or demand conditions that create asymmetric conditions between incumbents and new entrants impeding or preventing market entry of the latter. Such high structural barriers may be found to exist when the market is characterised by substantial economies of scale and/or economies of scope and high sunk costs, which may often be the case in communications markets. The notorious "last mile" is precisely a situation where such structural barriers are found to exist. A structural barrier can also exist where the provision of service requires a network component that cannot be technically duplicated or only duplicated at a cost that makes it uneconomic for competitors, which amounts not surprisingly to a situation similar to an essential facility. ${ }^{450}$

The entry barriers may also be legal or regulatory when they are not based on economic conditions, but result from legislative, administrative or other State measures that have direct effect on the conditions of entry or the positioning of operators on the relevant market.

448 Emphasis added.

${ }^{449}$ See in particular Recitals 9 to 16 of the Recommendation, as explained by Section 3.2 of the Explanatory Memorandum. For the first Relevant Market Recommendation, the Commission included all markets listed in the Annex I of the Framework Directive as suggested by the Council and the European Parliament. This list corresponds to the markets regulated before under the 1998 regulatory framework, albeit defined more precisely.

${ }^{450}$ See supra Section 2.3.2. 
Examples are legal or regulatory barriers preventing entry into a market where there is a limit on the number of undertakings having access to spectrum frequencies for the provision of the underlying services, existing price controls or other price related measures imposed on undertakings, which affect not only the entry but also the positioning of undertakings on the market. It should be noted that both types of barriers are non-strategic (i.e. they are not artificially induced by the firms on the markets but rather relate to objective characteristics of the markets themselves ${ }^{451}$ ) as it was considered that strategic barriers like excessive investment or reinforcement of network effects would require individual and episodic intervention, which would be better done under competition law. ${ }^{452}$ They thus correspond to the Community case law on barriers to entry, which we considered above in the Section on antitrust. 453

(ii) In view of the dynamic character and functioning of electronic communications markets, the possibilities to overcome the existing barriers within a relevant time horizon need also be taken into consideration when carrying out a prospective analysis to identify the relevant markets for possible ex ante regulation. The second criterion for market selection admits therefore only those markets the structure of which does not tend towards effective competition within the relevant time horizon. The application of this criterion involves examining the state of competition beyond the barriers of entry. This is, for instance, the case in markets with a limited, but sufficient, number of undertakings behind the entry barriers having diverging cost structures and facing price-elastic market demand. ${ }^{454}$ Entry barriers may also become less relevant with regard to innovation-driven markets characterised by ongoing technological progress. In such situations, competitive constraints often come from the threat of innovation by potential competitors that are not currently active in the market. ${ }^{455}$

(iii) The third criterion refers to the relative efficiency and sufficiency of competition law remedies in reducing and removing the barriers identified according to the two first criteria. The third criterion is thus fulfilled when ex ante, i.e. sector specific regulation would address more efficiently the market failure than competition law would. In cases, where the compliance requirements of the intervention are extensive (e.g. assessment of costs, detailed accounting) or where there is a special need for a timely or recurrent intervention, antitrust will be clearly less sufficient than sectoral rules.

Finally, a special attention is paid to new and emerging markets. In such markets, the market leader may de facto possess substantial market shares due to the "first mover advantage" intrinsic to newly formed markets. These markets should not however be subject to selection. Otherwise, a "premature imposition of ex ante regulation may unduly influence the

\footnotetext{
${ }^{451}$ MARTIN CAVE, “An Economic Analysis of Remedies in Network Industries" in DAMIEN GERADIN (ed.), Remedies in Network Industries: EC Competition Law vs. Sector-Specific Regulation, Antwerp: Intersentia, 2004, pp. 1-19, at p. 11.

452 ALEXANDRE DE STREEL, supra note 442, at p. 495.

453 See supra Section 2.2.1.3.B.

${ }^{454}$ For a definition of price elasticity of demand, see supra note 52.

455 On the importance of considering supply-side substitutability and potential competition in communications markets, see supra Section 2.2.1.1.B.
} 
competitive conditions taking shape within a new and emerging market. ${ }^{456}$ The Guidelines do nonetheless point out that, "[a]t the same time, foreclosure of such emerging markets by the leading undertaking should be prevented". ${ }^{457}$

The so-outlined criteria are to be applied cumulatively, so that failing any one of them, means that the market should not be identified in subsequent recommendations. ${ }^{458}$ As mentioned above, the selected markets are to be regularly reviewed by the Commission and accordingly updated to take account of the market developments. A reviewed framework and a new Recommendation are due by the end of $2006 .{ }^{459}$

\section{B. INTERIM OBSERVATIONS ON MARKET SELECTION}

In the context of the overall change of the European Community communications regulatory regime, the three criteria for market selection are indicative of the new approach towards greater reliance on competition law methodology and the desire to base decisions on economic rationales. Under the 1998 framework, the SMP regime was mainly related to markets previously under legal monopoly (such as, fixed voice networks and services and leased lines). Moreover, they were not markets within the meaning of competition law and practice, but rather based on technology-dependent definitions. Under the new directives, the SMP rules are eventually detached from the historical monopoly criterion and linked to more flexible criteria, such as barriers to entry and the inefficiency of antitrust to control market power. The latter change of paradigm, however, does not automatically mean deregulation. ${ }^{460}$ The first Recommendation on relevant markets, which identified eighteen markets (seven retail and eleven wholesale $)^{461}$ subject to further analysis, may indeed lead to more, rather

456 SMP Guidelines, at para. 32.

457 Ibid.

${ }^{458}$ A market could also be removed from a recommendation once there is evidence of sustainable and effective competition on that market within the Community, provided that the removal of existing regulation obligations would not reduce competition on that market. See Recital 16 of the Relevant Market Recommendation.

459 The review of the current Recommendation was scheduled for no later than 30 June 2004. The process was however substantially slowed. On the review, see EUROPEAN COMMISSION, Communication on market reviews under the EU regulatory framework: Consolidating the internal market for electronic communications, supra note 428 . For all relevant documents of the adoption process, see <http://europa.eu.int/information_society/policy/ecomm/tomorrow/adoption_process/index_en.htm>.

460 "Deregulation" in the sense of "the withdrawal of the State's legal powers to direct the economic conduct of nongovernmental bodies". See RICK GEDDES, "Public Utilities" in BOUDEWIJN BOUCKAERT and GERRIT DE GEEST (eds.), Encyclopaedia of Law and Economics, Cheltenham, UK: Edward Elgar Publishing, 2000, pp. 1162-1205, at p. 1168, referring the definitions given by George J. STIGler, "Regulation in Theory and Practice: An Overview, Comment" in GARY Fromm (ed.), Studies in Public Regulation, Cambridge, MA: MIT Press, 1981, pp. 73-77 and CLIFFORD WINSTON, “Economic Deregulation: Days of Reckoning for Microeconomists" (1993) Journal of Economic Literature, Vol. 31, No 3, pp. 1263-1289.

461 The markets listed in the Annex of current Relevant Marker Recommendation are as follows:

Retail Level:

1. Access to the public telephone network at a fixed location for residential customers;

2. Access to the public telephone network at a fixed location for non-residential customers;

3. Publicly available local and/or national telephone services provided at a fixed location for residential customers;

4. Publicly available international telephone services provided at a fixed location for residential customers;

5. Publicly available local and/or national telephone services provided at a fixed location for non-residential customers;

6. Publicly available international telephone services provided at a fixed location for non-residential customers;

7. The minimum set of leased lines (which comprises the specified types of leased lines up to and including $2 \mathrm{Mb} / \mathrm{sec}$ as referenced in Article 18 and Annex VII of the Universal Service Directive);

Wholesale level: 
than less, regulation. On the other hand, it should be noted that the Recommendation of 2003 followed the predefined markets included in Annex I of the Framework Directive ${ }^{462}$ and did not perform of fully-fledged analysis using the market selection criteria. ${ }^{463}$ Such a genuine analysis based on these criteria is expected with adoption of the new Commission's Recommendation in 2006.

In the broader frame, it is highly interesting to contemplate on the three criteria for market selection. In that sense, we can easily identify behind the three criteria some of the discussed characteristics. Firstly, the structural criterion corresponds to the natural monopoly characteristics of the communications sector related to high sunk costs, economies of scale and scope and the presence of network effects. Minding these features, the barriers to entry criterion may be furthermore related to the proneness of communications to bottleneck situations and to the possible incapability of competition rules to deal with those (through the application of the EFD ${ }^{464}$ ). The dynamic criterion reflects essentially the intrinsic dynamism of electronic communications. The third criterion, i.e. the efficiency of competition rules to address the arising problematic situation is indeed linked to the underlying question of the present work, namely: Can competition law do it all? In fact, when one takes all of these elements together and subsumes them under the above question, it seems that the new builtin mechanism of market selection may lead to "an extension or even perpetuation of sectoral regulation, even though the new directives were aimed to be de-regulatory". ${ }^{465}$

\section{PRODUCT AND GEOGRAPHICAL MARKET DEFINITION}

Taking "utmost account" 466 of the markets selected in the Commission Recommendation and the SMP Guidelines, the NRAs proceed with defining the relevant markets appropriate to national circumstances. Since the Commission has already identified the relevant markets

8. Call origination on the public telephone network provided at a fixed location;

9. Call termination on individual public telephone networks provided at a fixed location;

10. Transit services in the fixed public telephone network;

11. Wholesale unbundled access (including shared access) to metallic loops and sub-loops for the purpose of providing broadband and voice services;

12. Wholesale broadband access;

13. Wholesale terminating segments of leased lines;

14. Wholesale trunk segments of leased lines;

15. Access and call origination on public mobile telephone networks;

16. Voice call termination on individual mobile networks;

17. The wholesale national market for international roaming on public mobile networks;

18. Broadcasting transmission services, to deliver broadcast content to end users.

In addition to the above defined markets, there are also certain markets specifically identified in Article 6 of the Access Directive and Articles 18 and 19 of the Universal Service Directive.

462 See List of Markets to be included in the initial Commission Recommendation on relevant product and service markets referred to In Article 15, Annex I of the Framework Directive.

${ }^{463}$ On the genesis of the list of markets established by the Commission in the Recommendation and some policy issues behind it, see CHRISTIAN HOCEPIED, “The Approach to Market Definition in the Commission's Guidelines and Recommendation" in PIERRE A. BUIGUES and PATRICK REY (eds.), The Economics of Antitrust and Regulation in Telecommunications, Cheltenham, UK: Edward Elgar Publishing, 2004, pp. 71-87, at pp. 72-79.

464 As illustrated supra in Section 2.3.2.

465 ALEXANDRE DE STREEL, supra note 442, at p. 496.

466 See Recital 28 and Article 14(2) of the Framework Directive and supra note 423. 
susceptible to ex ante regulation, in practice the task of NRAs will normally be limited to defining only the geographical scope of the relevant market. Nevertheless, when justified by the national specificities, the NRAs may deviate from the markets given in the Recommendation and identify other relevant markets. ${ }^{467}$ The latter deviation equal to an additional market selection is subject however to the procedures set out in Article 7 of the Framework Directive, which could ultimately amount to a Commission's veto. ${ }^{468}$ So far, the NRAs have defined the majority of markets in line with the Relevant Market Recommendation, albeit with few exceptions - both in the sense of more narrowly and more broadly defined markets. ${ }^{469}$ Although it could be argued that a narrower definition of the market facilitates the finding of market power in it, "in the Commission's experience to date, such refinement has actually helped to deregulate the sector, as it has allowed regulation to be rolled back in those markets where sustainable competition has developed“. ${ }^{470}$ Other or narrower market definitions have however also been the result of not so accurate initial market selection by the Commission. Such is the case with the wholesale market for broadcasting transmission services, where most NRAs deviated from the Relevant Market Recommendation and subdivided the market by the platforms used (e.g. cable, satellite or terrestrial), the transmission mode (analogue or digital) and/or the signal transmitted (radio or television), ${ }^{471}$ since no interchangeability between those was found (yet).

As far as transnational markets susceptible to ex ante regulation are concerned, they are, where appropriate, to be identified by the Commission in a decision pursuant to Article 15(4) of the Framework Directive.

Following the overall antitrust spirit of the new regulatory framework, markets are defined and analysed using the same methodologies as under competition law. Therefore, the definition of the geographic scope of markets identified in the Recommendation, the definition where necessary of relevant product/services markets outside the Recommendation, and the

\footnotetext{
${ }^{467}$ There may be a number of ways in which market definition at a national level differs from the markets identified in the Recommendation. There might be narrower market definition at a national level of an identified market. According to national circumstances, there might be a reason to broaden the market definition such that two or more markets that are identified separately in the Recommendation could be identified as a single market. Similarly, there might be a reason to identify a newly developed market segment and combine it with a market identified in the Recommendation. According to national circumstances, there might also be a reason to identify additional markets to those identified by the Commission. See e.g. Cases UK/2003/00070010, UK Fixed Narrowband Retail Services Markets, Comments pursuant to Article 7(3) of Directive 2002/21/EC, SG (2003) D/2311951, 24 September 2003.

${ }^{468}$ See supra Section 3.2.1.2.

${ }^{469}$ EUROPEAN COMMISSION, Communication on market reviews under the EU regulatory framework: Consolidating the internal market for electronic communications, supra note 428, at p. 5. See also EUROPEAN COMMISSION, Annexes accompanying the Communication on market reviews under the EU regulatory framework: Consolidating the internal market for electronic communications [COM(2006) 28 final], SEC(2006) 86, 6 February 2006, at Annex II.

470 EUROPEAN COMMISSION, Communication on market reviews under the EU regulatory framework: Consolidating the internal market for electronic communications, supra note 428, at p. 5. The Commission points to the example of the delineation pf wholesale leased lines by bandwidth, which has allowed existing regulation in respect of very high bandwidth to be withdrawn in the United Kingdom.

${ }^{471}$ EUROPEAN COMMISSION, Communication on market reviews under the EU regulatory framework: Consolidating the internal market for electronic communications, ibid. at p. 9. EUROPEAN COMMISSION, Annexes accompanying the Communication on market reviews under the EU regulatory framework: Consolidating the internal market for electronic communications [COM(2006) 28 final], supra note 469, at Annex II, para. 1.13.
} 
assessment of effective competition by NRAs should be consistent with EC competition case law and practice. That is to say, that all the relevant competition rules and practice elaborated upon in Section 2 of this Chapter and generally all the case law of the Court of First Instance and the European Court of Justice concerning market definition and the notion of dominant position within the meaning of Article 82 EC, the Guidelines on the application of EEC competition rules in the telecommunications sector, ${ }^{472}$ the Commission Notice on the definition of relevant markets for the purposes of Community competition $\operatorname{law}^{473}$ and the Notice on the application of competition rules to access agreements in the telecommunications sector ${ }^{474}$ are fully applicable and to be taken into utmost consideration by the NRAs.

In this line, the NRAs define the geographic markets within their national territories (and other relevant markets, if adequate) depending on the existence of competitive constraints on the price-setting behaviour of the producer(s) or service provider(s) concerned. As discussed in the Sections on Article 82 EC, these are: (i) demand-side substitution; (ii) supply-side substitution and (iii) potential competition. In assessing those, NRAs apply the "hypothetical monopolist" test whereby the question asked is what happens if there were a small but significant non-transitory increase in the price (SSNIP) of a given product or service, assuming that the prices of all other products or services remain constant. The application of the SSNIP test as a method of identifying the boundaries of relevant electronic communications markets (both product/service and geographical dimensions) is identical with the one used under general competition law and analysed above. ${ }^{475}$

"The use of the same methodologies ensures that the relevant market defined for the purposes of sector specific regulation will in most cases correspond to the market definitions that would apply under competition law". ${ }^{476}$ This does not however mean that market definitions will coincide in all cases. As discussed above, market definition is not a mechanical or abstract process but requires an analysis of the available evidence of past market behaviour and moreover, an overall understanding of the mechanics of the sector in issue. In a sector as unique as electronic communications, the process of market definition is modified by the very specifics of the communications networks and services. Some vivid examples of divergence possibilities were already provided in the context of market definition under Article 82 EC. ${ }^{477}$ Besides these opportunities for discrepancy due to the specific environment to which antitrust methodology is applied (most notably, dynamism, convergence, multiple technological offerings and diverse consumer needs), there are certain slight but significant differences in the methodology itself, when compared to the one used under generic competition law.

A first cause for divergence in that respect is the price used for the "hypothetical monopolist" test. Within the context of market definition under Article 82 EC, a competition authority or a

\footnotetext{
472 See supra note 29.

${ }^{473}$ See supra note 40.

${ }^{474}$ See supra note 61.

475 See supra Section 2.2.1.1.

476 SMP Guidelines, at para. 25 (emphasis added).

${ }^{477}$ See supra Section 2.2.1.2.
} 
court would estimate the starting price for applying the SSNIP test on the basis of the price charged by the alleged monopolist. Likewise, under the prospective assessment of the effects, which a merger may have on competition, the starting price would be based on the prevailing prices of the merging parties. However, where an NRA carries out a market analysis, the service or product in question may be offered by several firms. In such a case, the starting price should be the industry average price. ${ }^{478}$

Far more important difference in comparison to standard competition law than the above is the perspective of assessment of the NRAs. Markets defined under Articles 81 and 82 EC are generally defined on an ex post basis. Thus, in these cases, the analysis will consider events that have already taken place in the market and will not be influenced by possible future developments. Conversely, although NRAs should not ignore, where relevant, past evidence, they will assess the relevant markets for the purposes of sector specific regulation always on a forward-looking basis, including in the assessment an appreciation of the future development of the market. The starting point for carrying out market analysis for the purpose of Article 15 of the Framework Directive (i.e. market definition) is not the existence of an agreement or concerted practice within the scope of Article $81 \mathrm{EC}$, nor a concentration within the scope of the Merger Regulation, nor an alleged abuse of dominance within the scope of Article 82 EC. It is rather based on an "overall forward-looking assessment of the structure and the functioning of the market under examination". ${ }^{479}$ Although NRAs and competition authorities, when examining the same issues in the same circumstances and with the same objectives, should in principle reach the same conclusions, it cannot be excluded that, given the differences outlined above, and in particular the broader focus of the NRAs' assessment, markets defined for the purposes of competition law and markets defined for the purpose of sector specific regulation may not always be identical. ${ }^{480}$

The ex ante perspective and the assessment of the ever-evolving communications markets will make the difference. ${ }^{481}$ The Commission has pointed out in that regard that "[w]hilst prospective analysis of market conditions may in some cases lead to a market definition different from that resulting from a market analysis based on past behaviour, NRAs should nonetheless seek to preserve, where possible, consistency in the methodology adopted between, on the one hand, market definitions developed for the purposes of ex ante regulation, and on the other hand, market definitions developed for the purposes of the application of competition rules. Nonetheless, as stated in Article 15(1) of the Framework Directive and

478 SMP Guidelines, at footnote 29.

479 SMP Guidelines, at para. 27 (emphasis added).

480 Ibid.

${ }^{481}$ Although merger analysis is also applied ex ante, it is not carried out periodically as is the case with the analysis of the NRAs under the new regulatory framework. A competition authority does not, in principle, have the opportunity to conduct a periodic review of its decision in the light of market developments, whereas NRAs are bound to review their decisions periodically under Article 16(1) of the Framework Directive. This factor can influence the scope and breadth of the market analysis and the competitive assessment carried out by NRAs, and for this reason, market definitions under the new regulatory framework, even in similar areas, may, in some cases, be different from those markets defined by competition authorities. 
Section 1 of the Guidelines, markets defined under sector-specific regulation are defined without prejudice to markets that may be defined in specific cases under competition law". 482

\section{INTERIM CONCLUSION ON MARKET DEFINITION}

Market definition under the current EC regulatory framework for electronic communications is much more complex and refined an exercise in comparison to the previous regime. In fact, under the 1998 regulatory framework, market definition was based merely on certain specific aspects of end-to-end communications rather than on demand and supply substitutability criteria and hence the relevant markets defined were not markets in competition law sense. Moreover, the role of the NRAs with regard to the market definition process was virtually non-existent and all "markets" were pre-defined in the ONP Directives. Presently, market definition "is not any more an engineering exercise that is based on technological differences, but it is an economist task based on relative substitutions". ${ }^{483}$ The use of antitrust principles has certainly made the definition of the relevant product and services markets far more flexible and thus capable of reflecting the rapid changes in communications markets. However, this new flexibility bestows a heavy burden upon the regulatory agencies who will have to conduct a fairly complex forward-looking analysis of the national markets and at the same time pursue consistency of approaches and definitions throughout the European Community. The specific nature of electronic communication as a sector and its incredible dynamism present a major challenge in that respect. ${ }^{484}$

\subsubsection{MARKET ANALYSIS}

Following the definition of the relevant markets (both in the sense of product or service dimension and geographic scope), the NRAs must analyse them to find out whether they are effectively competitive. "Effective competition" 485 is the basic trigger for NRAs' action (or nonaction) and amounts to a finding that no operator (or operators) enjoys a dominant position or is able to leverage dominance. Conversely, if there are one or more undertakings with significant market power on the market under scrutiny, the market is deemed not to be effectively competitive. ${ }^{486}$

482 SMP Guidelines, at para. 37 (footnote omitted; emphasis added). For further comparison between sector specific regulation and competition rules, see infra Section 3.2.4.5.

483 ALEXANDRE DE STREEL, supra note 442, at p. 501.

484 The Commission has stated explicitly in the SMP Guidelines that, “...in a sector characterised by constant innovation and rapid technological convergence, it is clear that any current market definition runs the risk of becoming inaccurate or irrelevant in the near future". See Guidelines on market analysis. at para. 63, referring to Joined Cases T-125/97 and T-127/97 The Coca-Cola Company and Others v. Commission [2000] ECR II-1733, [2000] 5 CMLR 467, at paras 81 and 82.

${ }^{485}$ On effective competition, see JENS-DANIEL BRAUN and RALF CAPITO, supra note 443, at pp. 319-331. See also RICHARD WHISH, supra note 15 , at pp. 15-16.

486 "It is essential that ex ante regulatory obligations should only be imposed where there is not effective competition, i.e. in markets where there are one or more undertakings with significant market power, and where national and Community competition law are not sufficient to address the problem". See Framework Directive, at Recital 27. 


\section{A. STANDARD ANTITRUST ANALYSIS}

According to Article 14 of the Framework Directive "an undertaking shall be deemed to have significant market power if, either individually or jointly with others, it enjoys a position equivalent to dominance, that is to say a position of economic strength affording it the power to behave to an appreciable extent independently of competitors customers and ultimately consumers". By subscribing to the latter definition, which the settled case law ascribes to the concept of dominant position under Article $82 \mathrm{EC},{ }^{487}$ the SMP regime has in effect been aligned with generic EC competition law. The previously existing 25 per cent market share threshold for assigning significant market power as a shortcut to sector specific obligations is rendered obsolete. ${ }^{488}$ Consequently, in applying the new definition of SMP, NRAs will have to ensure that their decisions are in accordance with the Commission's practice and the relevant jurisprudence of the Court of Justice and the Court of First Instance on dominance. The concepts of single and collective dominance, ${ }^{489}$ leverage of market power and the essential facilities doctrine become fully applicable under the new design of electronic communications sector specific regulation. ${ }^{490}$ Notably, again, as within the context of market definition with some important differences: As formulated by the Commission, "[t]he application of the new definition of SMP, ex ante, calls for certain methodological adjustments to be made regarding the way market power is assessed". ${ }^{491}$

\section{B. IDIOSYNCRASIES OF THE COMMUNICATIONS SPECIFIC MARKET ANALYSIS}

Firstly, and most importantly, the perspective of the NRAs' analysis is quite different from the one under Article 82 EC. In carrying out the market analysis, NRAs have to conduct a forwardlooking, structural evaluation of the relevant market, based on existing market conditions. ${ }^{492}$ In that sense, the regulatory agencies must determine whether the market is prospectively competitive and thus, whether any lack of effective competition is durable, ${ }^{493}$ by taking into account expected or foreseeable market developments over the course of a reasonable period.

\footnotetext{
${ }^{487}$ Case 27/76 United Brands v. Commission, supra note 35.

${ }^{488}$ As stated in the Framework Directive at Recital 25, "[t]he definition of significant market power in the Directive 97/33/EC of the European Parliament and of the Council of 30 June on interconnection in telecommunications with regard to ensuring universal service and interoperability through application of the principle of open network provision (ONP) has proved effective in the initial stages of market opening as the threshold for ex ante obligations, but now needs to be adapted to suit more complex and dynamic markets. For this reason, the definition used in this Directive is equivalent to the concept of dominance as defined in the case law of the Court of Justice and the Court of First Instance of the European Communities" (footnote omitted).

489 There is extensive guidance on the application of the concept of collective dominance. Annex II of the Framework Directive contains a list of criteria (non-exhaustive and non-cumulative) to be used by the NRAs in making an assessment of joint dominance. See also the SMP Guidelines, at paras 86-106. For a critique of the inclusion of complex dominance concepts in the communications regime, see ANTONIO BAVASSO, Communications in EU Antitrust Law, The Hague/London/Boston: Kluwer Law International, 2003, at pp. 62-66. Generally on collective dominance, see GIORGIO MONTI, "The Scope of Collective Dominance under Article 82 EC“ (2001) Common Market Law Review, Vol. 38, pp. 131-157.

${ }^{490}$ For analysis of some of these competition law notions, see supra Sections $2.3 \mathrm{et} \mathrm{seq.} \mathrm{For} \mathrm{a} \mathrm{comprehensive} \mathrm{analysis} \mathrm{of} \mathrm{all,} \mathrm{see}$ e.g. JONATHAN FAULL and Ali NiKPAY, supra note 19 and RiCHARD WHISH, supra note 15.

491 SMP Guidelines, at para. 70.

492 SMP Guidelines, at para. 75.

${ }^{493}$ Recital 27 of the Framework Directive.
} 
The actual period used has to reflect the specific characteristics of the market and the expected timing for the next review of the relevant market by the NRA.

Hence, when assessing ex ante whether one or more undertakings are in dominant position, NRAs will, in principle, be relying on different sets of assumptions and expectations than those relied upon by competition authorities applying ex post Article $82 \mathrm{EC}$ within the context of an alleged committed abuse. In an ex post analysis, a competition authority may be faced with a number of different examples indicative of market power within the meaning of Article 82 EC. In an ex ante environment, however, market power will essentially be measured by reference of the power of the undertaking to raise prices by restricting output without significant loss of sales or revenues. ${ }^{494}$ Often, the lack of evidence or records of past behaviour will mean that the market analysis will have to be based mainly on a prospective assessment. The accuracy of the market analysis carried out by the NRAs will thus often be conditioned by the information and data existing at the time of the adoption of the relevant decision.

The fact that NRA's initial market predictions do not ultimately materialise in a given case does not necessarily mean that its decision at the time of its adoption was inconsistent with the Framework Directive. In applying ex ante the concept of dominance, NRAs are indeed accorded some discretionary powers correlative to the complex character of the economic, factual and legal situations that would need to be assessed. In accordance with the Framework Directive, market assessments by NRAs have to be undertaken on a regular basis. The recurrence of the NRAs' analysis allows the agencies to react at regular intervals to any market developments and to take any measure deemed necessary (thus possibly correcting prior "mistakes"). ${ }^{495}$

In the process of prospective market analysis, the NRAs should notably also consider the potential competition, i.e. the likelihood that undertakings not currently active on the relevant product market may in the medium term decide to enter the market following a small but significant non-transitory price increase. Undertakings which, in case of such a price increase, are in a position to switch or extend their line of production/services and enter the market should be treated by NRAs as potential market participants even if they do not currently produce the relevant product or offer the relevant service.

As far as emerging markets are concerned, Recital 27 of the Framework Directive notes that emerging markets, where de facto the market leader is likely to have a substantial market share, should not be subject to inappropriate ex ante regulation. Premature imposition of ex ante regulation may unduly influence the competitive conditions taking shape within new and emerging markets.

Finally, with regard to the designation of an undertaking as having SMP, it is important to emphasise that the SMP designation has no bearing on whether that undertaking has committed abuse of dominant position in the meaning of Article 82 EC. It merely implies that,

494 SMP Guidelines, at para. 73.

495 SMP Guidelines, at para. 71. 
from a structural perspective, and in the short to medium term, the operator has and will have, on the identified relevant market, sufficient market power to behave to an appreciable extent independently of competitors, customers, and ultimately consumers for the purpose of the communications specific rules. ${ }^{496}$

\section{INTERIM CONCLUSION ON MARKET ANALYSIS}

Market analysis is a complex process with many variables based on factual, economic and legal data. NRAs undoubtedly profit from the practice and the experience gathered by the European Commission and the Community Courts when applying the competition law concepts of single and joint dominance, leverage of power and essential facilities. Nevertheless, it should be noted that the application of these competition law notions, which are fairly intricate in themselves, ${ }^{497}$ has to be done from an $e x$ ante forward-looking perspective, probably often based on limited information. The regulatory burden on the NRAs in that sense is enormous since they will sometimes have to "see into the future" and sanction the present when deciding whether there is effective competition on the relevant market at issue. The repercussions of this exercise could indeed be grave.

\subsubsection{REMEDIES}

The third step within the SMP algorithm and a crucial one for the proper functioning of the electronic communications markets is the imposition, maintenance, amendment or withdrawal, as appropriate, of specific regulatory obligations on undertakings designated as having SMP.

As already explained in the previous Section on market analysis, effective competition is the "litmus test" of the regulatory regime. It is a notion, which means that there is no undertaking with significant market power on the relevant market. Under Article 16 of the Framework Directive if an NRA finds that a relevant market is subject to effective competition, it is not allowed to impose obligations on any operator in that relevant market. If the NRA has previously imposed regulatory obligations on undertaking(s) in that market, it must withdraw them. ${ }^{498}$

Accordingly, if an NRA finds that competition in the relevant market is not effective because of the existence of an undertaking or undertakings in dominant position, it must designate in accordance with Article 16(4) of the Framework Directive the undertaking (or undertakings) concerned as having SMP and impose appropriate regulatory obligations on these

${ }^{496}$ SMP Guidelines, at para. 30.

${ }^{497}$ As exemplified by the analyses of the abusive practices of refusal to supply and tying. See supra Sections 2.3.1 and 2.3.3.

${ }^{498}$ After giving the affected parties a reasonable period of notice. With regard to removal of obligations in markets for conditional access and other facilities, there are additional conditions besides the presence of effective competition on these markets. Pursuant to Article 6(3), subparagraph 2 of the Access Directive, NRAs may amend or withdraw obligations, only to the extent that: (a) accessibility for end-users to radio and television broadcasts and broadcasting channels and services would not be adversely affected by such amendment or withdrawal and (b) the prospects for effective competition in the markets for: (i) retail digital television and radio broadcasting services and (ii) conditional access systems and other associated facilities, would not be adversely affected by such amendment or withdrawal. 
undertaking(s). However, merely designating an undertaking as having SMP on a given market, without imposing any appropriate regulatory obligations, will be inconsistent with the provisions of the regulatory framework. ${ }^{499}$ Thus, there is a direct connection between the SMP designation and the imposition of remedies and the NRA must impose at least one regulatory obligation on the undertaking designated as having SMP. Where an NRA determines the existence of more than one undertaking with dominance, i.e. that a joint dominant position exists, it should determine the most appropriate regulatory obligations to be imposed, based on the principle of proportionality.

If an undertaking was previously subject to obligations under the 1998 regulatory framework, the NRA must consider whether similar obligations continue to be appropriate under the new framework, based on the new market analysis. If the undertaking is found to have SMP in a relevant market under the new framework, regulatory obligations similar to those imposed under the 1998 regulatory framework may therefore be maintained. Alternatively, such obligations could be amended or new obligations imposed according to the particular case at issue and the assessment of the NRA.

NRAs can choose between a range of regulatory obligations set out in the Specific Directives in order to remedy a particular problem in a market found not to be effectively competitive. The latter "freedom" is limited only by the international commitments of the European Community, i.e. notably its obligations in the WTO relating to major suppliers of basic telecommunications services ${ }^{500}$ and when the Directives prescribe explicitly particular remedies, such as under Article 18 and 19 of the Universal Service Directive.

The specific regulatory obligations which may be imposed on SMP undertakings can apply both to wholesale and retail markets. In principle, the obligations related to wholesale markets are contained in Articles 9 to 13 of the Access Directive and encompass: (i) transparency (Article 9); (ii) non-discrimination (Article 10); (iii) accounting separation (Article 11); (iv) obligations for access to and use of specific network facilities (Article 12); and (v) price control and cost accounting obligations (Article 13).

The obligations designed for retail markets are set out in Articles 17 to 19 of the Universal Service Directive. These are: (i) regulatory controls on retail services (Article 17); (ii) availability of the minimum set of leased lines (Article 18 and Annex VII); and (iii) carrier selection and pre-selection (Article 19). The following paragraphs will shed some light upon each of these remedies. ${ }^{501}$

\footnotetext{
${ }^{499}$ Article 16(4) of the Framework Directive.

500 See Council Decision 94/800/EC of 22 December 1994, concerning the conclusion on behalf of the European Community, as regards matters within its competence, of the agreements reached in the Uruguay Round multilateral negotiations (1986-1994), OJ L 336/191, 23 December 1994, especially the General Agreement on Trade in Services and the Annex on Telecommunications and also Council Decision 97/838/EC concerning the conclusion on behalf of the European Community, as regards matters within its competence, of the results of the WTO negotiations on basic telecommunications services, OJ L 347/45, 18 December 1997.

501 See extensively on the different remedies and their appropriateness, European Regulators Group of National Regulatory Authorities (ERG), Common Position on the Approach to Appropriate Remedies in the New Regulatory Framework, ERG (03) 30rev1, 1 April 2004.
} 


\section{A. Obligations Regarding Wholesale Markets}

Wholesale markets signify the relationship between the providers of electronic communications networks and services and relate to the main issues of infrastructure and access to infrastructure. The menu of sector specific obligations available to the NRAs to remedy the lack of effective competition in such markets are the following:

(i) Firstly, under Article 9 of the Access Directive, NRAs may impose an obligation of transparency in relation to interconnection and/or access, requiring the operators to make public specified information, such as accounting information, technical specifications, network characteristics, terms and conditions for supply, use and prices. In particular, where an operator has obligations of non-discrimination, the authority may require the publication of a reference offer, ${ }^{502}$ which shall be sufficiently unbundled ${ }^{503}$ to ensure that undertakings are not required to pay for facilities, which are unnecessary for the requested service. NRAs may specify the precise information to be made available, the level of detail required and the manner of publication.

(ii) Secondly, NRAs may impose an obligation of non-discrimination pursuant to Article 10 of the Access Directive. The latter pursues to ensure that the operator applies equivalent conditions in equivalent circumstances to other undertakings providing equivalent services. Vertically integrated firms should provide services and information to others under the same conditions and quality as it provides for its own services, or for those of its own subsidiaries or partners.

(iii) Thirdly, under Article 11 of the Access Directive, NRAs may impose an obligation of accounting separation. ${ }^{504}$ This relates in particular to vertically integrated companies and requires them to make transparent their wholesale and internal transfer prices in order to ensure compliance, where there is a requirement for non-discrimination under Article 10 or, where necessary, to prevent cross-subsidisation. In that context, the national agencies have the power to require that accounting records, including data on revenues received from third parties, are provided on request. NRAs may even publish such information, as this would contribute to an open and competitive market, while necessarily respecting national and Community rules on commercial confidentiality.

(iv) The fourth instrument available to NRAs is the obligation of access to, and use of, specific network facilities pursuant to Article 12 of the Access Directive. In the words of the latter provision, a NRA may "impose obligations on operators to meet reasonable requests for

502 According to Article 9(4) of the Access Directive, when an operator should give access to the twisted metallic pair local loop, the NRA should ensure the publication of a reference offer containing at least the elements set out in Annex II of the Access Directive, including, inter alia, information on the conditions for unbundled access to the local loop, co-location services, information systems and the supply conditions. The NRAs can impose further changes to the reference offers to give effect to obligations imposed under the Access Directive.

503 "Sufficiently unbundled" offer, if translated from the telecommunications jargon, means that the offer is sufficiently broken down to its constituent elements and detailed. The same term is used under the WTO Reference Paper.

504 See also EUROPEAN COMMISSION, Recommendation of 19 September 2005 on accounting separation and cost accounting under the regulatory framework for electronic communications, supra note 426. 
access to, and use of, specific network elements and associated facilities, inter alia in situations where the national regulatory authority considers that denial of access or unreasonable terms and conditions having a similar effect would hinder the emergence of a sustainable competitive market at the retail level, or would not be in the end-user's interest". ${ }^{205}$ The specific obligations may be, among others, giving third parties access, including access to the local loop; negotiating in good faith with undertakings requesting access; not withdrawing access from already granted facilities; providing specified services on a wholesale basis for resale by third parties; granting open access to technical interfaces, protocols or other key technologies that are indispensable for the interoperability of services or virtual network services; providing co-location or other forms of facility sharing; providing specified services needed to ensure interoperability of end-to-end services to users; providing access to operational support systems or similar software systems necessary to ensure fair competition in the provision of services; interconnecting networks or network facilities.

In addition to the above requirements, NRAs may attach conditions covering fairness, reasonableness and timeliness.

(v) The last remedy in the menu of the Access Directive is the possibility to impose price control and cost accounting obligations. ${ }^{506}$ These may include obligations for cost-orientation of prices and obligations concerning cost accounting systems for the provision of specific types of interconnection and/or access in situations, where a market analysis indicates that a lack of effective competition means that the operator concerned might sustain prices at an excessively high level ${ }^{507}$ or apply a price squeeze ${ }^{508}$ to the detriment of end-users. ${ }^{509}$ Thus, NRAs may exercise negative price control preventing excessive and predatory pricing, or price squeezes. In addition, they may also impose positive price control provided it promotes efficiency and allows the operator a reasonable rate of return on adequate capital employed, taking into account the risks involved. ${ }^{510}$

\footnotetext{
${ }^{505}$ Article 12(1) of the Access Directive.

506 Article 13 of the Access Directive.

${ }^{507}$ On excessive pricing and predatory pricing, see Access Notice, at paras 105-109 and 110-116 respectively.

508 On price squeeze, see Access Notice, at paras 117-119.

${ }^{509}$ Recital 20 of the Access Directive states with regard to price control that, "[p]rice control may be necessary when market analysis in a particular market reveals inefficient competition. The regulatory intervention may be relatively light, such as an obligation that prices for carrier selection are reasonable as laid down in Directive 97/33/EC, or much heavier such as an obligation that prices are cost oriented to provide full justification for those prices where competition is not sufficiently strong to prevent excessive pricing. In particular, operators with significant market power should avoid a price squeeze whereby the difference between their retail prices and the interconnection prices charged to competitors who provide similar retail services is not adequate to ensure sustainable competition. When a national regulatory authority calculates costs incurred in establishing a service mandated under this Directive, it is appropriate to allow a reasonable return on the capital employed including appropriate labour and building costs, with the value of capital adjusted where necessary to reflect the current valuation of assets and efficiency of operations. The method of cost recovery should be appropriate to the circumstances taking account of the need to promote efficiency and sustainable competition and maximise consumer benefits".

${ }^{510}$ On the different methods of price control, see ALEXANDRE DE STREEL, supra note 442, at pp. 506-507.
} 


\section{B. CHOICE OF REMEDIES}

NRAs can apply one (at least), several or all of the above package of sector specific obligations. The precise remedy prescribed depends on the concrete situation and the NRAs' assessment of this situation. In any case, the choice of measure(s) to be imposed on the SMP operator(s) must be justified in relation to the objectives set out in Article 8 of the Framework Directive (i.e. promotion of competition, the internal market and the interests of the citizens of the European Union) and must be proportionate to the achievement of these objectives.

This pursuit of proportionality is one of the fundamental features of the current regulatory framework and brings in a new level of flexibility in comparison to the previously existing system, where the NRAs had to apply upon SMP designation automatically the whole set of remedies. In essence, the principle of proportionality requires that the means used to attain a given end should be no more than what is appropriate and necessary to attain that end. In order to establish that a proposed measure is compatible with the principle of proportionality, the action taken must pursue a legitimate aim and the means employed to achieve the aim must be both necessary and the least burdensome for the achievement of the goal. ${ }^{511}$

An essentially new principle that the NRAs will have to observe while fulfilling their tasks is that of technological neutrality. It was acknowledged during the consultations of the 2002 framework that it is of primary importance for any regulatory measure taken with regard to electronic communications markets to be neutral as to the technology used. ${ }^{512}$ In a sector as dynamic and technologically driven as electronic communications, a technologically biased measure might steer the process in a wrong direction and seriously harm innovation and competition in the markets and for the markets. The presence of networks effects additionally aggravates the situation since the market might settle at an inferior standard due to a decision partial to a certain technology or technological solution. In that context acknowledging the gravity of neutrality, the Framework Directive defines as an obligation for the Member States to "ensure that in carrying out the regulatory tasks in this Directive and the Specific Directives, in particular those to ensure effective competition, national regulatory authorities take the utmost account of the desirability of making regulations technologically neutral" ${ }^{513}$

This principle should be fully considered but not exaggerated. Essentially, almost every choice made or decision taken by the regulatory agencies in communications markets will have some technological repercussions. Avoiding these would amount to not taking any decisions at all. That is why, Recital 18 of the Framework Directive clarifies that the requirement of technological neutrality "does not preclude the taking of proportionate steps to promote certain specific services where this is justified, for example digital television as a

511 See Article 5(3) of the EC Treaty and the Protocol on the application of the principles of subsidiarity and proportionality attached to the Treaty of Amsterdam Amending the Treaty on European Union, the Treaties Establishing the European Communities and Related Acts, OJ C 340/1, 10 November 1997. See generally also NichOLAS EmILIOU, The Principle of Proportionality: A Comparative Study, The Hague/London/Boston: Kluwer Law International, 1996, at Chapter 4.

512 See e.g. "Principles for Regulatory Action" in the 1999 Communications Review, at p. v.

${ }^{513}$ Article 8(1) of the Framework Directive. See also PAUl NiHOUL and PETER RODFORD, supra note 4, at paras 7.128-7.129. 
means for increasing spectrum efficiency". ${ }^{514}$ Nihoul and Rodford remark in the context of technological neutrality that the latter principle "must be understood as a prohibition on adopting stances which, as their main object, imply that a given technology is favoured. A reasonable interpretation is that other choices, with ancillary consequences on technology, could be accepted". 515

\section{INTERIM OBSERVATIONS ON WHOLESALE MARKETS REMEDIES}

The remedies listed in the Access Directive provide NRAs with a potent toolkit to confront undertakings having SMP and thus could serve to promote effective competition on the wholesale market in question. Ranging from the obligation of transparency to price control, they allow the regulatory authorities to be both flexible in designing a specific remedy package for specific problems and fairly intrusive if a radical intervention is needed. ${ }^{516}$

The "obligation of access to, and use of, specific network facilities" 517 gives NRAs the opportunity to intervene in situations where access is denied or withdrawn when this would "hinder the emergence of a sustainable competitive market at the retail level, or would not be in the end-user's interest" ${ }^{\prime \prime}{ }^{18}$ In that sense, the test for imposing third-party access under the sector specific regulation appears to be broader and more loosely defined ${ }^{519}$ and thus more easily met than under competition law. Indeed, under the essential facility doctrine, access may only be granted when the facility is essential, which according to the standing case law of the European Courts, as we ascertained above, is a rather rigid test. ${ }^{520}$ Against the background of the entire infrastructure-based or service-based competition discussion and accounting for the importance of access, NRAs will have to be extremely conscious when applying the tool of mandatory access. They should at all times safeguard competition in the long run taking into due account the investments and risks taken by the facility owner.

Price control in the form of cost-orientation, as enshrined in Article 13 of the Access Directive, is another instrument that can be quite intrusive and possibly curb rather than stimulate competition, if unduly applied.521 It should thus only be used with extreme prudence and be confined to cases close to existence of an essential facility (as the case of the local loop). ${ }^{522}$ Where there is network duplication like in the mobile industry, non-discrimination or other forms of price control may be preferable.

\footnotetext{
514 On digital television interoperability, see e.g. Recitals 30, 31 and Article 18 of the Framework Directive.

515 PAUl NiHOUL and PETER RODFORD, supra note 4, at para. 7.129.

516 For an economic evaluation of the remedies and their costs and benefits, see MARTIN CAVE and PIERRE LAROUCHE (Rapporteurs), "European Communications at the Crossroads", Report of the CEPS (Centre for European Policy Studies) Working Party on Electronic Communications, Brussels: Centre for European Policy Studies, October 2001, at p. 14.

517 Article 12 of the Access Directive.

518 Article 12(1) of the Access Directive.

519 MARTIN CAVE, supra note 451, at p. 14.

520 See supra Section 2.3.2, in particular the analysis of the seminal Case C-7/97 Oscar Bronner, supra note 200.

${ }^{521}$ MARTIN CAVE, supra note 451, at pp. 15-16.

522 MARTIN CAVE, supra note 402 , at p. 37.
} 
On the whole, it appears that the further one goes on the ascending scale of remedies from Article 9 to 13 of the Access Directive, the more one needs to prove that the SMP is strong and persistent, ${ }^{523}$ since the remedy becomes "harder". The intrusiveness of these sector specific obligations should, nonetheless, not be overstated. Any intervention under sectoral regulation is in fact limited to the markets selected by the Commission as "markets susceptible to ex ante regulation". ${ }^{524}$ In addition to the market selection test, all measures regarding market definition and market analysis, taken by the NRAs, are subject to the special regulatory procedure of Article 7 of the Framework Directive. ${ }^{525}$ It should however be borne in mind that, with specific regard to remedies, the Commission can comment on their appropriateness, ${ }^{526}$ but has no power to veto them.

\section{OBLIGATIONS IMPOSED ON RETAIL MARKETS}

Retail markets signify the relationship between the providers of electronic communications networks and services and the end-users (be it business or residential customers). Although the process of market analysis is identical to the one regarding wholesale markets, two conditions must be fulfilled for the imposition of obligations on a retail market. The first one is the same as for wholesale markets, namely that one or more operators are found to enjoy an SMP position. The second, additional one is that the obligations that may be imposed on wholesale markets under the Access Directive (as outlined above) or Article 19 of the Universal Service Directive (i.e. carrier selection and pre-selection) would not result in the achievement of the Article 8 Framework Directive objectives. ${ }^{527}$ This means that obligations on retail markets should only be imposed when the remedies on the wholesale markets will not be effective. The rationale behind the latter rule is that as most of the retail anti-competitive behaviour stems from the exercise of market power on the wholesale market, it is more appropriate to regulate it as a source of the problem, rather than the retail market where the problem might manifest itself. Retail regulation would thus only be justified when wholesale regulation would be too late or is too complex or insufficient. Therewith, the new framework envisages in practice a reduction of retail regulation. One should however remember that competition rules continue to apply fully and constantly to all markets.

When the above negative conditions are fulfilled and retail market regulation is still found to be necessary, the NRA may impose one or more obligations choosing from the non-exhaustive list provided in Article 17 of the Universal Service Directive. The obligations imposed must satisfy the same conditions as those for the wholesale markets, i.e. be based on the nature on

${ }^{523}$ See supra the elaborations in the context of abuse of dominant position under Article 82 EC (Section 2.3), which tend to suggest that a firm in a dominant position "has a special responsibility not to allow its conduct to impair undistorted competition on the common market" (Case 322/81 Michelin v. Commission, supra note 44, at para. 57).

524 See supra Section 3.2.4.2.

525 See supra Section 3.2.1.2.

526 The Commission has commented for instance on remedies that solved the problem at issue only partly, appeared to be inadequate or might have produced effective result too late. See EUROPEAN COMMISSION, Communication on market reviews under the EU regulatory framework: Consolidating the internal market for electronic communications, supra note 428, at pp. 5-6.

527 Article 17 of the Universal Service Directive. 
the problem identified, while being also proportionate and justified in the light of the Article 8 objectives. The obligations may include requirements that the identified undertakings do not charge excessive prices, inhibit market entry or restrict competition by setting predatory prices, show undue preference to specific end-users or unreasonably bundle services. In addition, NRAs may apply to such undertakings the same type of price control measures as to wholesale markets, i.e. appropriate price cap measures, measures to control individual tariffs, or measures to orient tariffs towards costs or prices on comparable markets. ${ }^{528}$

\section{E. EXCEPTIONS}

All of the preceding parts of this Section set out the procedures whereby certain specific obligations may be imposed on undertakings enjoying SMP. Exceptionally, similar obligations could be imposed on operators other than those designated as having SMP. These exceptions are contained in Article 8(3) of the Access Directive and the obligations to be imposed are of rather diverse nature. What is common to all of them is that they are all justified by the specific characteristics of electronic communications and the need for safeguarding competition and the public interest. Thus, Article 8(3) of the Access Directive allows, among others, the imposition of obligations covering access to conditional access systems, obligations to interconnect to ensure end-to-end interoperability and access to application programme interfaces and electronic programme guides to ensure accessibility to specified digital TV and radio broadcasting services. ${ }^{529}$ Since the imposition of these obligations upon firms that do not in fact have dominance constitutes a major intervention into the operation of the market, NRAs are to use these exceptions with great care. ${ }^{530}$

${ }^{528}$ In addition to the above, under Article 18 of the Universal Directive, the NRAs can impose price controls on the minimum set of leased lines if they find that the market for the provision of part or all of it, as identified in the list of standards, is not effectively competitive. See List of standards and/or specifications for electronic communications networks, services and associated facilities and services, supra note 415 .

529 The full list of obligations covered by Article 8(3) of the Access Directive is as follows: (i) obligations covering access to conditional access systems, obligations to interconnect to ensure end-to-end interoperability, and access to application program interfaces and electronic programme guides to ensure accessibility to specified digital TV and radio broadcasting services (Article 5(1), 5(2) and 6 of the Access Directive); (ii) obligations for co-location where rules relating to environmental protection, health, security or town and country planning deprive other undertakings of viable alternatives to co-location (Article 12 of the Framework Directive); (iii) obligations for accounting separation on undertakings providing electronic communications services who enjoy special or exclusive rights in other sectors (Article 13 of the Framework Directive); (iv) obligations relating to commitments made by an undertaking in the course of a competitive or comparative selection procedure for a right of use of radio frequency (Condition B7 of the Annex to the Authorisation Directive, applied via Article 6(1) of that Directive); (v) obligations to handle calls to subscribers using specific numbering resources and obligations necessary for the implementation of number portability (Articles 27, 28 and 30 of the Universal Service Directive); (vi) obligations based on the relevant provisions of the Data Protection Directive; and (vii) obligations to be imposed on non-SMP operators in order to comply with the Community's international commitments.

530 The Commission has expressed its concerns in the Tenth Communications Report, where it stated that, "[i]t needs to be highlighted that the power to impose access and interconnection related obligations on non-SMP operators has to be used with great care, as there is always a risk that excessive or unjustified use of the powers under Article 5 could undermine a key principle of the new framework - that competition related remedies should be based on the findings of a market analysis. The Commission is therefore following closely the development of NRA practice in the application of Article 5 of the Directive as part of the notification process under Article 7 of the Framework Directive". See EUROPEAN COMMISSION, European Electronic Communications Regulation and Markets 2004, supra note 120, Vol. I, at p. 24. 
An important exception is the one related to obligations imposed on non-SMP operators in order to comply with the Community's international commitments. ${ }^{531}$ The European Communities and their Member States are signatories to the agreements adopted in the realm of the WTO and as such carry to responsibility of having certain appropriate measures applied to undertakings qualifying as "major suppliers", which may or may not be identical with the ones identified as having significant market power.

In a different vein of exceptions, the national regulators may impose other obligations for access and interconnection than those listed in the Access Directive. In order to do so, the NRA must submit a request to that effect to the Commission, which takes a decision authorising or preventing the measure. ${ }^{532}$ There are no limitations given to the character and the scope of these other measures. Although all prescribed measures in the Access Directive are behavioural, a structural solution (including divesture) could, at least in theory, also be adopted if the Commission could be convinced that the proposed structural remedy is indeed the only adequate solution and all other available remedies would be inefficient.

\subsubsection{A BRIEF COMPARISON OF THE NEW SECTOR SPECIFIC REGULATION AND GENERIC COMPETITION RULES}

Before concluding on the European Community's regime for electronic communications networks and services in the general context of this Chapter on regulation, it will be interesting to make a brief comparison of the "new" sector specific regulation (as opposed to the "old" ONP rules ${ }^{53}$ ) and generic EC competition rules. The gist of the 2002 regulatory framework is that specific economic regulation applies when and until it can control market power more efficiently than antitrust. Although the sector specific rules are now aligned with competition law methodologies, as evident from the above Sections, one could not submit that they coincide. Such a submission will indeed be flawed. In reality, the two sets of public intervention (competition law and sector specific regulation) continue to exist as separate systems. They should, however, be seen as complimentary, rather than as substitutes. ${ }^{534}$

As pointed out by the Commission SMP Guidelines, in practice, it cannot be excluded that parallel procedures under ex ante regulation and competition law may arise with respect to different kinds of problems in relevant markets. Competition authorities may therefore carry out their own market analyses and impose appropriate competition law remedies alongside any sector specific measures applied by NRAs. However, it must be noted that such simultaneous application of remedies by different regulators would address different problems in such markets. Ex ante obligations aim to fulfil the specific objectives set out in the relevant

\footnotetext{
531 Article 8(3)(vii) of the Access Directive.

532 Article 8(3) of the Access Directive. The Commission must seek the advice of the Communications Committee before taking its decision.

533 The comparison between the "old" and the "new" sectoral regulation was done in the course of examining market definition, market analysis and imposition of remedies, albeit not exhaustively. For a comprehensive analysis, see PAUL NIHOUL and PETER RODFORD, supra note 4, at paras 2.97 et seq. and 3.273 et seq.

534 See Guidelines on application of EEC competition rules in the telecommunications sector, supra note 29, at para. 17; Access Notice, at para. 58. See also supra Section 3.1.3 and PAUL NiHOUL, supra note 377.
} 
directives, whereas competition law remedies aim to sanction agreements or abusive behaviour, which prevent, restrict or distort competition in the relevant e-communications market. ${ }^{535}$

Despite certain convergence of the goals pursued by the current communications specific regulation and EC competition rules (most notably, their focus on economic efficiency), ${ }^{536}$ the conditions of intervention vary substantially according to the instruments applied. The SMP regime is limited to market structures fulfilling certain criteria that amount to a certain number of "markets" in competition law sense, as selected by the Commission. The SMP regime applies then generally each time when there are one or more dominant undertakings on such a market. Abuse or other particular behaviour by the undertaking(s) in question is not a necessary element.

In contrast, competition law is triggered only by a specific behaviour of the firms (be it agreement or concerted practice, concentration or abusive behaviour) that should be proven to be exploitative or anti-competitive. ${ }^{537}$ In the light of the above, it seems that within the current SMP regime the burden of proof is fairly high when selecting a market, but becomes quite low to justify an intervention. This solution is in fact understandable and appropriate. It is the very purpose of sectoral regulation to apply to markets where ongoing interventions are needed and moreover, to apply ex ante in order to prevent anti-competitive behaviour (rather than to punish it ex post as under general competition law).

The assessment of the intervention conditions (through market definition, market analysis and assessment of market power) may also differ under antitrust and communications specific regulation, as shown above. The use of the same methodologies does not necessarily secure exactly the same outcome and the latter may in different contexts be different. ${ }^{538}$ Indeed, the market under sector specific rules will be normally defined more broadly than under competition rules.

Firstly, because the starting point for the analysis is different: the market selection is conducted according to broader criteria. High barriers to entry, state of competition and dynamism behind the barriers, and relative efficiency of sectoral remedies are much wider when compared with the standard antitrust criterion of demand substitutability. Secondly, the market analysis that follows under the SMP regime is, notably, a forward-looking one. As explained by the Commission's Notice on market definition, the concept of the relevant market is closely linked to the objectives pursued under Community policies. That is why the markets under Articles 81 and 82 EC are generally defined on an ex post basis and the analysis considers specific events that have already taken place in the market and is not influenced by

\footnotetext{
${ }^{535}$ SMP Guidelines, at para. 31.

536 See AlEXANDRE DE STREel, supra note 442, at p. 510 and AlEXANDRE DE STREEL, "Remedies in the European Electronic Communications Sector" in DAMIEN GERADIN (ed.), Remedies in Network Industries: EC Competition Law vs. Sector-Specific Regulation, Antwerp: Intersentia, 2004, pp. 67-124, at pp. 117 et seq. See also PAUL NIHOUL and PETER RODFORD, supra note 4, at para. 4.374 .

537 As discussed in supra Section 2.3.

538 SMP Guidelines, at paras 24-32.
} 
possible future developments. Even in an analysis undertaken under the Merger Control Regulation, ${ }^{539}$ which is as a rule conducted ex ante, the focus is quite different. Merger analyses are not carried out periodically as is the case and the very essence of the analyses of the NRAs under the 2002 regulatory framework. Competition authorities do not, in principle, have the opportunity to conduct a periodic review of its decisions in the light of market developments, whereas NRAs are bound to do so under Article 16(1) of the Framework Directive. The latter factor can influence the scope and breadth of the market analysis and the competitive assessment carried out by NRAs. For this reason, market definitions under the new regime, even in similar areas, may be different from those markets defined by antitrust authorities.

Given the above differences, as pointed out by the SMP Guidelines, the designation of an undertaking as having SMP in a market identified for the purpose of ex ante regulation does not automatically imply that this undertaking is also dominant for the purpose of Article 82 EC or similar national provisions. To reiterate in the words of the Commission, "...the SMP designation has no bearing on whether that undertaking has committed an abuse of a dominant position within the meaning of Article 82 EC or national competition laws. It merely implies that, from a structural perspective, and in the short to medium term, the operator has and will have, on the relevant market identified, sufficient market power to behave to an appreciable extent independently of competitors, customers, and ultimately consumers, and this, solely for purposes of Article 14 of the Framework Directive". ${ }^{440}$

Finally, as discussed in detail above, the remedies that may be imposed differ. Although, in principle, both behavioural and structural instruments may be used under competition ${ }^{541}$ and sectoral law, some sectoral remedies may go further than antitrust ones.

The table below summarises the afore-drawn conclusions in the context of comparing the new SMP regime and generic competition law rules.

${ }^{539}$ Council Regulation (EC) 139/2004 on the control of concentrations between undertakings, supra note 22.

540 SMP Guidelines, at para. 30.

${ }^{541}$ Regulation 17/62 (Council Regulation 17 of 6 February 1962, First Regulation implementing Articles 85 and 86 of the Treaty, OJ 13/204, 21 February 1962) did not specifically provide for structural remedies. Now, under the new "modernisation" Regulation (supra note 15), this is made possible. Article 7(1) therein states however that structural remedies can be imposed only "where there is no equally effective behavioural remedy or where any equally effective behavioural remedy would be more burdensome for the undertaking concerned than the structural remedy". 


\section{FIGURE FIVE: DifFERENCES BETWEEN THE SMP REGIME AND COMPETITION LAW}

\begin{tabular}{|c|c|c|}
\hline FEATURE & SMP REGIME & COMPETITION LAW \\
\hline POLICY FOCUS & $\begin{array}{l}\text { - Three policy objectives (Article } 8 \\
\text { Framework Directive): effective } \\
\text { competition, internal market, interests } \\
\text { of the citizens } \\
\text { - To promote competition }\end{array}$ & $\begin{array}{l}\text { - Prohibits abuses of dominant position, } \\
\text { agreements between undertakings and } \\
\text { concentrations that restrict or distort } \\
\text { competition } \\
\text { - To protect competition }\end{array}$ \\
\hline SCOPE & $\begin{array}{l}\text { - Industry specific (exclusive for } \\
\text { electronic communications) } \\
\text { - Selected market structures where } \\
\text { competition law intervention would be } \\
\text { inefficient }\end{array}$ & $\begin{array}{l}\text { - Economy wide, multiple industries } \\
\text { - All market structures }\end{array}$ \\
\hline $\begin{array}{l}\text { CONDITIONS } \\
\text { Intervention / } \\
\text { process }\end{array}$ & $\begin{array}{l}\text { - Low burden of proof to intervene on } \\
\text { selected markets } \\
\text { - } \quad \text { Prospective always } \\
\text { - } \text { Decision of general application and } \\
\text { specific issue proceedings } \\
\text { - } \text { Mix of formal and less formal } \\
\text { procedures with public consultation }\end{array}$ & $\begin{array}{l}\text { - High burden of proof to intervene, } \\
\text { particularly for ex post control } \\
\text { - Retrospective under Article } 82 \mathrm{EC} \text { or } \\
\text { prospective under Merger control } \\
\text { - Complaint or investigation driven } \\
\text { (adjudicative process) } \\
\text { - Formal investigation procedures }\end{array}$ \\
\hline REMEDIES & $\begin{array}{l}\text { - } \text { Broad scope for public intervention: } \\
\text { - } \text { Strong to prescribe } \\
\text { remedies } \\
\text { - Ongoing monitoring on behavioural } \\
\text { - Remedies may be far-reaching and } \\
\text { heavier than antitrust }\end{array}$ & $\begin{array}{l}\text { - Narrow scope for public intervention: } \\
\text { used to proscribe } \\
\text { - Emphasis on behavioural remedies for ex } \\
\text { post control or structural remedies for ex } \\
\text { ante control } \\
\text { - Idiosyncratic, one-off interventions }\end{array}$ \\
\hline
\end{tabular}

SOURCE: ALEXANDRE DE STREEL ${ }^{542}$

\subsubsection{CONCLUSIONS ON THE NEW SMP REGIME}

The 2002 regime for market analysis and assessment of Significant Market Power is the core of the reform undertaken in European Community communications regulation. The newly formulated SMP rules are based on "imported" competition law concepts and methodology and as a mechanism are meant to ensure the transition from sector specific regulation to application of competition law rules only, as competition takes hold on the relevant communications markets. As visible from the Sections above, the regime is undoubtedly more flexible and refined than the previously existing rather rigid sectoral regulation, in particular with regard to market definition, finding of dominance and imposition of obligations and thus allows for swift adjustments to the developments of electronic communications. It profits also from the legal practice and case law of the Community's institutions in the field of antitrust and increasingly rests on economic principles that create a sound and reliable regulatory

${ }^{542}$ Based with modifications on ALEXANDRE DE STREEL, supra note 442, at p. 513. 
system. These features of the 2002 SMP framework can be truly categorised as advantages for the further development of the e-communications sector but carry simultaneously certain risks.

The latter are above all related to the application of the SMP regime. The national regulatory authorities will have to live up to the challenges of implementing a far more complex system of rules and show sensitivity to the communications market developments. The assessment of significant market power, including application of the sometimes hard-to-define complex dominance concepts like collective dominance and leverage of market power, will not be an easy task and at the same time of crucial importance. The same is equally true for the choice of the specific obligations that the NRAs will impose on the designated SMP undertaking(s), where the particular design of the specific measures (that could also be rather intrusive) will have to match the identified market problem and provide an efficient solution. Furthermore, the NRAs will have to take into consideration the development of emerging markets and ensure that all actions and measures taken are technologically neutral. All this will notably have to be done in the pursuit of effective competition, development of the internal market and promoting the interests of the citizens ${ }^{543}$ and in a manner ensuring consistency of the approaches and the practice throughout the European Community. Thus, in broader terms, one can conclude that the NRAs are entrusted with the task of "micro-managing" 544 the electronic communications sector from the current state to effective competition, a task that is indeed a heavy burden. ${ }^{545}$

To put it bluntly in the words of Alexandre de Streel, "[i]f the NRAs do not do their job properly and/or if the courts do not show any deference to these authorities, their decisions will be constantly challenged by the regulated operators and the new framework could end up being like Communist thinking: interesting in theory but a failure in practice" .546

Yet, to conclude in a more optimistic air, the design of the new SMP regime is undoubtedly a step in the right direction for European Community's communications regulation. ${ }^{547}$ The previously existing regulatory asymmetry has been overcome and the given flexibility matches more adequately the dynamic nature of the sector. The emerged new hybrid type of sectoral communications regulation follows the well-established lines of antitrust analyses, while allowing also for tailoring the regulatory intervention along the specific characteristics of electronic communications, addressing both dominance-related issues (such as access) and other issues (such as end-to-end interoperability).

${ }^{543}$ As prescribed by Article 8 of the Framework Directive.

${ }^{544}$ A term used by Alison Oldale and Atilano Jorge Padilla, "From State Monopoly to the 'Investment Ladder': Competition Policy and the NRF" in MATS A. BERGMAN and ARVID NiLSSON (eds.), The Pros and Cons of Antitrust in Deregulated Markets, Stockholm: Swedish Competition Authority, 2004, at pp. 51-77.

${ }^{545}$ For a sceptical view that the NRAs could carry this burden properly, see ALISON OLDALE and ATILANO JORGE PADILLA, ibid. at pp. 70 et seq.

546 ALEXANDRE DE STREEL, supra note 442, at pp. 512-513.

${ }^{547}$ Mark Naftel and Lawrence Spiwak conclude in that sense their chapter on the EU 1999 Telecommunications Review. Therein, they state that, "[i]n conclusion, the approach of the 1999 Review should be considered as a step in the right direction. A test of its effectiveness may be how fast, if ever, it puts regulators out of business". See MARK NAFTEL and LAWRENCE J. SPIWAK, supra note 400 , at p. 360 . 
The experience gathered during the past three years of applying the SMP regime shows that the system does function. However, one should note that if deregulation was the goal pursued by the 2002 package, it was most certainly not achieved. Withdrawal of regulation is a fact but it is not as sweeping as one might have expected. In the words of the Commission, "[w]hereas certain markets have exhibited the characteristics of enduring bottlenecks, a number of markets have already become effectively competitive in several Member States, allowing existing regulation to be rolled back". ${ }^{548}$ The truth behind this diplomatic statement is that of all 152 analysed markets until September 2005 (out of 450), 123 were found not competitive, only 19 fully competitive and 10 partially competitive. ${ }^{549}$ Upon these data, one could venture a conclusion that communications markets exhibit characteristics that do not lead to the withdrawal of sectoral rules, despite the fact that the necessary mechanisms are put in place. Since some of the communications specificities are lasting, a continuation of regulation is highly plausible.

\section{CONCLUSIONS}

It is difficult to provide a straightforward conclusion to the above quite extensive and heterogeneous Chapter on communications regulation. It was in any case not the purpose of the Chapter to end unequivocally. Its purpose was rather, in the context of the overall frame of this work, to examine the regulatory instruments available and applied to European Community communications markets, and to provide therewith a foundation for further reflection.

As we have seen, these tools form a complex system with intricate relationships between the individual bodies of law, which are in themselves rather elaborate systems of regulation. The EC competition rules and the communications specific regime have essentially different origins and inspirations as regulatory systems and have been created to achieve different ends using different means. Because of these dissimilarities, their regulatory potential is not the same.

In the preceding Chapter, we discovered that the tools applicable to communications have not always been in their present shape and form. The European Community communications law has indeed evolved immensely in the last couple of decades. From a simple set of sectoral rules regulating the national monopolists within the individual Member States without competition law supervision to a comprehensive dual system of antitrust and sector specific instruments. The application of the liberalisation and harmonisation measures has accordingly transformed the telecommunications sector from monopoly to a state of competition. A multiplicity of players is presently active in the diverse electronic

\footnotetext{
${ }^{548}$ EUROPEAN COMMISSION, Communication on market reviews under the EU regulatory framework: Consolidating the internal market for electronic communications, supra note 428, at p. 10 (emphasis in the original).

${ }^{549}$ European COMmission, "Telecom Liberalisation: EU Rules Help to Free Up Markets But Much Remains to Be Done", IP/06/125, Brussels, 7 February 2006. See also EUROPEAN COMMISSION, Annexes accompanying the Communication on market reviews under the EU regulatory framework: Consolidating the internal market for electronic communications [COM(2006) 28 final], supra note 469, at Annexes I and III.
} 
communications markets, the economic parameters show above average growth and the role of the sector as the basis for the Information Society and various other policy endeavours is vital.

The 2002 framework for electronic communications, which was central to our analysis above, has been designed to respond to this newly attained level of competition. It pursues to regulate the sector in the face of convergence and rapid technological and market developments, and "to continue to do so for the foreseeable future without major revision". 550 The latter task is admittedly not an easy one considering the fact that communications is unlike any other sector of the economy and is in itself a complex system with multiple factors and forces simultaneously at work. ${ }^{551}$

The 2002 package has attempted to live up to these challenges by implementing a few novel regulatory solutions and a finer, more flexible structure. Most crucially, it includes a new design of the communications specific regulation. The latter has been aligned with antitrust methodology and is currently based on standard competition law concepts and analyses (although, as seen above, with some perceptible differences). The new sectoral regime overcomes regulatory asymmetry and seeks a middle way between classical specific rules and competition law in that it provides for an in-depth antitrust analysis of the sector but on an ongoing, forward-looking basis with the possibility of ex ante regulatory intervention. The subscription of the new sector specific regulation to antitrust methodology does not however change its regulatory nature. Neither does the existing mechanism of withdrawing sectoral rules mean an overnight abolition of the dual regime. Firstly, because of the observable deficiency of EC competition rules, in particular Article 82 EC, to deal with situations of market power in the communications markets. Secondly, because the failures manifest in the communications ecosystem are not necessarily resulting from dominance but also from other phenomena, stemming from the very specificities of electronic communications.

Against the backdrop of our examination of EC communications tools and their evolvement over time, one could however make an interesting observation, namely that regulators have learned to approach communications situations more flexibly. They do observe the market developments and on the basis of these observations, adapt the applicable rules. A recent example of this learning adaptation process is the change of the Swiss telecommunications law providing for compulsory unbundling of the local loop, which was adopted notably not as

550 PAUl NiHOUl and PETER RODFORD, supra note 4, at p. vii.

${ }^{551}$ P.H. Longstaff cites Dietrich Dorner to provide a visualisation of complex systems and prove the difficulty of regulating them, "We could liken a decision maker in a complex situation to a chess player whose set has many more than the normal number of pieces, several dozen, say. Furthermore, these chessmen are all linked to each other by rubber bands, so that the player cannot move just one figure alone. Also, his men and his opponent's men can move on their own and in accordance with rules the player does not fully understand or about which he has mistaken assumptions. And, to top things off, some of his and his opponent's men are surrounded by a fog that obscures their identity". See P.H. LONGSTAFF, The Communications Toolkit, Cambridge, MA: MIT Press, 2003, p. 16. 
a definitive measure but scheduled for a period of four years, upon the expiry of which the situation of the communications markets would be assessed anew. ${ }^{552}$ The ongoing review of the EC electronic communications framework and the initiative of adopting a Regulation on International Mobile Roaming, ${ }^{553}$ i.e. a new communications specific binding instrument, are further proofs of this hypothesis.

552 See Fernmeldegesetz (RS 784.10), Änderung vom 24. März 2006, (BBl 2006 3565). See also “Etwas Schub auf der letzten Meile“, Neue Zürcher Zeitung, 25 March 2006.

553 See European COMMISSION, "International Mobile Roaming: Commissioner Reding Outlines Proposal for an EU Regulation to Bring Down Prices and Presents New Figures", IP/06/386, Brussels, 28 March 2006 and EuROPEAN COMMISSION, "New EU Regulation on International Mobile Roaming: Commission Opens Final Phase of Consultations", IP/06/420, 3 April 2006. 